University of Rhode Island

DigitalCommons@URI

Open Access Dissertations

2017

\title{
Greenhouse Gas Emissions from Biological Nutrient Removal During Wastewater Treatment
}

Elizabeth Quinn Brannon

University of Rhode Island, ebrannon@my.uri.edu

Follow this and additional works at: https://digitalcommons.uri.edu/oa_diss

\section{Recommended Citation}

Brannon, Elizabeth Quinn, "Greenhouse Gas Emissions from Biological Nutrient Removal During Wastewater Treatment" (2017). Open Access Dissertations. Paper 568.

https://digitalcommons.uri.edu/oa_diss/568

This Dissertation is brought to you for free and open access by DigitalCommons@URI. It has been accepted for inclusion in Open Access Dissertations by an authorized administrator of DigitalCommons@URI. For more information, please contact digitalcommons-group@uri.edu. 


\section{GREENHOUSE GAS EMISSIONS FROM BIOLOGICAL NUTRIENT REMOVAL DURING WASTEWATER TREATMENT \\ BY \\ ELIZABETH QUINN BRANNON}

A DISSERTATION SUBMITTED IN PARTIAL FULFILLMENT OF THE REQUIREMENTS FOR THE DEGREE OF DOCTOR OF PHILOSOPHY

IN

BIOLOGICAL AND ENVIRONMENTAL SCIENCES

UNIVERSITY OF RHODE ISLAND 
DOCTOR OF PHILOSOPHY DISSERTATION

$\mathrm{OF}$

\section{ELIZABETH QUINN BRANNON}

\section{APPROVED:}

Dissertation Committee:

$\begin{array}{ll}\text { Major Professor } & \text { Serena Moseman-Valtierra } \\ \text { Bethany Jenkins } \\ \text { Jose Amador } \\ \text { Nasser H. Zawia } \\ \text { DEAN OF THE GRADUATE SCHOOL }\end{array}$

UNIVERSITY OF RHODE ISLAND

2017 


\begin{abstract}
Since the 1900s, humans have been altering the global nitrogen $(\mathrm{N})$ cycle by industrially fixing $\mathrm{N}$ for fertilizer production. This reactive $\mathrm{N}$ is often released back to coastal environments through many mechanisms, including wastewater treatment, where it can lead to numerous consequences such as fish kills and algae blooms.

In many locations, wastewater treatment effluent is one of the largest sources of excess $\mathrm{N}$ to coastal environments. Although regulations limiting $\mathrm{N}$ loads in wastewater effluent in the U.S. were first developed in the 1970s, stricter regulations started to emerge in many states in the 2000s. In order to meet new discharge requirements, many centralized wastewater treatment plants (WWTPs) and onsite wastewater systems (OWTS) have been upgraded to include biological nitrogen removal (BNR) systems. These BNR systems make use of nitrifying and denitrifying bacteria to convert reactive forms of $\mathrm{N}$ (ammonium and nitrate) to nitrogen gas. Current BNR systems can reduce effluent total $\mathrm{N}$ loads to below $5 \mathrm{mg} / \mathrm{L}$. However, nitrous oxide $\left(\mathrm{N}_{2} \mathrm{O}\right)$, a greenhouse gas $(\mathrm{GHG})$ over 200 times more potent than carbon dioxide $\left(\mathrm{CO}_{2}\right)$, may be produced along with or instead of nitrogen gas. Further, organisms that respire $\mathrm{CO}_{2}$ and produce methane $\left(\mathrm{CH}_{4}\right)$ have been documented in BNR systems, making these systems potential sources of these additional potent GHGs. The BNR systems at WWTPs and OWTS can vary in many ways including the order and number of the different zones or compartments (aerated, anoxic, and anaerobic) and recycling arrangements. Therefore, although BNR systems at both WWTPs and OWTS may reduce N loads to coastal ecosystems, they may release GHGs that contribute to climate change.
\end{abstract}


The central objective of this research was to examine the magnitude, variability, and potential production mechanisms of GHG emissions from a BNR system at a WWTP and advanced OWTS. This research is timely as BNR systems are increasingly used at both WWTPs and OWTS, but differences in the systems can result in different GHG emissions and $\mathrm{N}$ removal efficiency.

Greenhouse gas emissions were measured using a cavity ring down spectroscopy (CRDS) analyzer (Picarro G2508) capable of measuring $\mathrm{N}_{2} \mathrm{O}, \mathrm{CO}_{2}$, and $\mathrm{CH}_{4}$ nearly simultaneously in real time. To first evaluate this new technology, a comparison study was conducted (Chapter 1) to test the CRDS (Picarro G2508) relative to two alternative methods for measuring GHG emissions, Gas Chromatograph (Shimadzu GC 2014) and Los Gatos $\mathrm{N}_{2} \mathrm{O}$ analyzer. The results of the study indicated that the detection limit of the Picarro was an order of magnitude lower than that of the Gas Chromatograph, but an order of magnitude higher than that of the Los Gatos $\mathrm{N}_{2} \mathrm{O}$ analyzer. Although both the Picarro and Los Gatos analyzers offer efficient and precise alternatives to GC-based methods, the Picarro has the unique capability of measuring all three GHGs $\left(\mathrm{N}_{2} \mathrm{O}, \mathrm{CO}_{2}\right.$, and $\mathrm{CH}_{4}$ ) simultaneously. Therefore, the Picarro was deemed suitable for use in the WWTP and OWTS studies.

Two major studies examining GHG emissions from a WWTP and OWTS were performed. The first was a yearlong study to determine the temporal (bi-monthly across annual cycle) and spatial (4 major zones: pre-anoxic, aerated IFAS, post-anoxic, and reaeration) variability of $\mathrm{GHG}\left(\mathrm{N}_{2} \mathrm{O}, \mathrm{CO}_{2}\right.$, and $\left.\mathrm{CH}_{4}\right)$ emissions from an Integrated Fixed Film Activated Sludge (IFAS) BNR system at the Field's Point WWTP in Providence, RI (Chapter 2). In addition, to understand environmental controls on the GHG 
emissions, potential relationships between the GHG emissions and water and tank parameters were examined. Finally, the emissions of all three GHGs were used to evaluate the importance of the BNR system to the overall GHG budget of the WWTP. The results of this study indicated that emissions of all 3 GHGs were highest from the aerated IFAS zone and all 3 GHGs varied by season (hourly variation was examined in Appendix 1). The $\mathrm{N}_{2} \mathrm{O}$ emissions were related to both ammonium and nitrate. When considering the emissions of all $3 \mathrm{GHGs}$ in terms of $\mathrm{CO}_{2}$ equivalence, $\mathrm{BNR}$ is responsible for approximately $12 \%$ of the total GHG emissions for the Field's Point WWTP (including emissions from: electricity, natural gas, liquid fuel, sludge disposal, and supplemental carbon). Generally, the BNR tank had higher emissions of all three GHGs than other parts of the treatment train (grit chambers, primary clarifiers, final clarifiers) (Appendix 2). However, the $\mathrm{N}_{2} \mathrm{O}$ emissions from the BNR tank represented only $0.01-0.34 \%$ of the influent N. Appendix 3 investigated the use of isotopomers to determine the mechanisms of $\mathrm{N}_{2} \mathrm{O}$ production from the BNR tank.

The second major study compared $\mathrm{N}_{2} \mathrm{O}$ emissions from the BNR system at the Field's Point WWTP to those from three common types of advanced OWTS used in RI to remove $\mathrm{N}$ (Advantex, SeptiTech, and FAST) (Chapter 3) $\left(\mathrm{CH}_{4}\right.$ and $\mathrm{CO}_{2}$ emission measurements are reported in Appendix 4). The emissions were compared in terms of normalized per capita emissions and emission factors (\% of $\mathrm{N}$ removed released as $\mathrm{N}_{2} \mathrm{O}$ ). In addition, the specific abundance of a nitrification gene (ammonium monooxygenase, amoA) and denitrification gene (nitrous oxide reductase, nos $Z$ ) were quantified in order to determine the abundance of microorganisms that may be producing $\mathrm{N}_{2} \mathrm{O}$ in these systems. The results of this study (Chapter 3 ) indicated that in 
general $\mathrm{N}_{2} \mathrm{O}$ emissions from $\mathrm{N}$ removal during wastewater treatment were $<1 \%$ of the $\mathrm{N}$ removed, except for one SeptiTech system (4\%) and one Advantex system (21\%). In general, $\mathrm{N}_{2} \mathrm{O}$ emissions (on a mole/area basis) from the WWTP were larger than those from OWTS and the OWTS with the largest $\mathrm{N}_{2} \mathrm{O}$ emissions was Advantex. However, when $\mathrm{N}_{2} \mathrm{O}$ emissions were normalized per capita and surface area of the treatment tank, they were similar between the WWTP and OWTS. Although there was no linear relationship between $\mathrm{N}_{2} \mathrm{O}$ emissions and amoA or nos $Z$ abundances, amoA and nos $Z$ abundances did differ between the WWTP and OWTS.

The results of this dissertation allow us to focus future research efforts on the zones (aerated IFAS at WWTP) and systems (WWTP and Advantex OWTS) that produced higher emissions. In addition, future studies should try to develop a better understanding of the large temporal and spatial variability observed in these systems. The results of this research determined that $\mathrm{N}_{2} \mathrm{O}$ emissions were related to both ammonium and nitrate, indicating that both nitrification and denitrification likely play a role in $\mathrm{N}_{2} \mathrm{O}$ emissions. However, preliminary isotopomer results indicate that nitrification may be responsible for the $\mathrm{N}_{2} \mathrm{O}$ emissions. With additional studies on the mechanisms of production, suggestions to operators can be made so that emissions can be lowered while maintaining $\mathrm{N}$ removal. 


\section{ACKNOWLEDGMENTS}

While at the University of Rhode Island (URI) I had the privilege of working with an accomplished, diverse, and interdisciplinary committee. First, I thank my dissertation advisor, Dr. Serena Moseman-Valtierra. From the beginning she supported my interest in teaching, whether it was helping me find TA opportunities or allowing me to help with lesson plans. She has helped me become an independent researcher, mentor, and educator. I also express thanks to my other committee members, Dr. Bethany Jenkins, Dr. Jose Amador, Dr. Art Gold, and Dr. Vinka Craver, for their guidance through my Ph.D. Not only did they serve as committee members, but as role models as I continue my career.

My dissertation would not have been possible without the help of undergraduate research assistants both in the lab and the field. I want to specially recognize Ryan Quinn (EPSCoR SURF Fellows, 2014), Katie Lynch (EPSCoR SURF Fellows, 2015), Isabella China, and Gina Celeste (Coastal Fellow, 2016). These students were extremely dedicated, whether it was braving the smell at the WWTP or long lab days on the GC. I would like to thank all of these students for granting me the opportunity to mentor them as they pursue their careers in science.

I had an extremely supportive MV Lab family throughout my Ph.D. starting with Dr. Rose Martin and Melanie Garate and ending with Katelyn Szura and Ashley Hogan. I want to thank all of them for their support in the lab, field, and class. I am also grateful for the support I received from fellow graduate students outside of the MV lab including Zachary Chejanovski, Kelsey James, Brittany Lancellotti, Ashley Marranzino, and Sara Wigginton. I will miss everyone but look forward to our yearly reunions at conferences. 
A large portion of the research presented in this dissertation was performed at the Narragansett Bay Commission's Field's Point wastewater treatment plant. I would like to thank them for allowing consistent access to the plant, without which this research would not have been possible. I would especially like to thank the following people for their help in the field at the plant and consistent sharing of data collected by the plant operators: Jim McCaughey, Barry Wenskowicz, Dave Aucoin, and Brendan Cunha.

Access to the Genomics and Sequencing Center at URI was also crucial to the completion of this research. I would like to thank the Genomics and Sequencing Center along with Janet Atoyan for her assistance with the equipment available there.

The funding for the research presented in this dissertation was provided by the United States Department of Agriculture (USDA) National Institute of Food and Agriculture (Hatch project \#229286, granted to Dr. Serena Moseman-Valtierra), the Rhode Island Research Alliance Collaborative, Narragansett Bay Commission, and the URI Enhancement of Graduate Research Award.

Last but not least I thank my family, starting with my other half Karl Wing. Although he is not a trained scientist, that didn't stop Karl from offering support, whether it was teaching me new excel tricks or listening to countless practice talks for conferences and classes. I also thank my parents, Gail and Rick Brannon, who placed a value on my education from the beginning and have always supported my pursuits. Finally, I thank my siblings Riley and Sarah Brannon for all their love and support. 


\section{PREFACE}

This dissertation is prepared in manuscript format. Chapter 1, entitled "Evaluation of laser-based spectrometers for greenhouse gas flux measurements in coastal marshes" was published in Limnology and Oceanography in July 2016. Chapter 2, entitled " $\mathrm{N}_{2} \mathrm{O}, \mathrm{CO}_{2}$ and $\mathrm{CH}_{4}$ fluxes from the largest IFAS biological nitrogen removal wastewater treatment systems in the U.S." has been submitted to Water Research. Chapter 3, entitled "Comparison of $\mathrm{N}_{2} \mathrm{O}$ emissions and gene abundances between nitrogen removal systems" has been submitted to the Journal of Environmental Quality. Chapter 1 is presented as it was accepted for publication in July 2016. Additional information for manuscripts, including additional authors, are noted at the beginning of each chapter. Appendices are presented at the end of the dissertation and contain data conducted in support of this dissertation but were not included in the manuscripts. 


\section{TABLE OF CONTENTS}

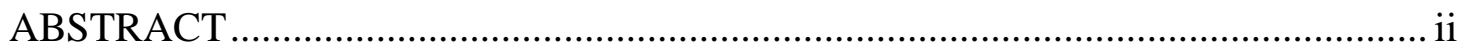

ACKNOWLEDGMENTS .................................................................................. vi

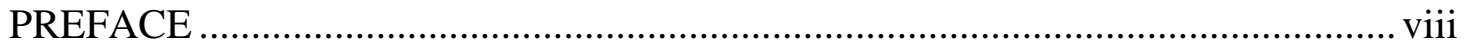

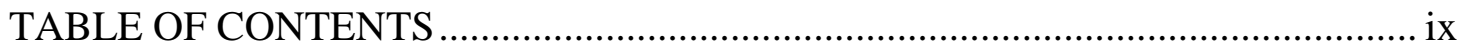

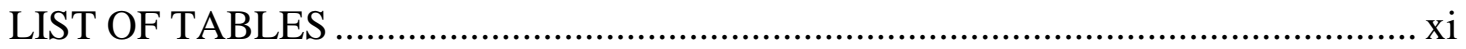

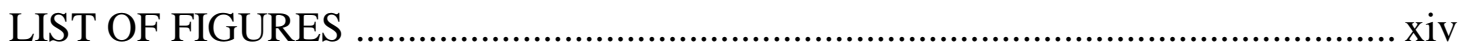

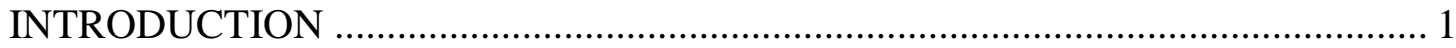

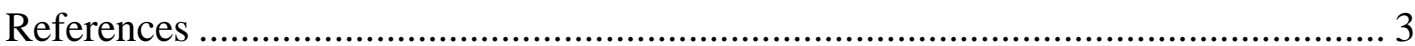

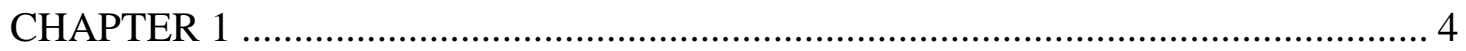

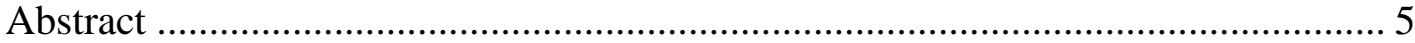

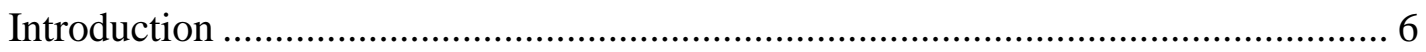

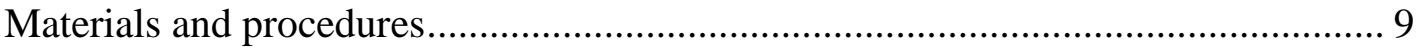

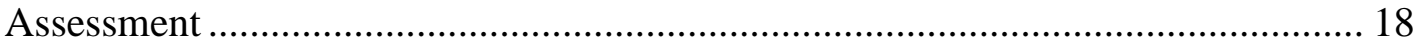

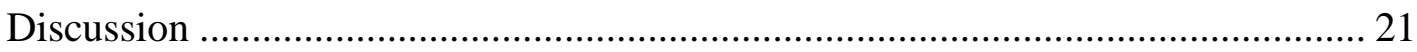

Comments and recommendations ................................................................... 24

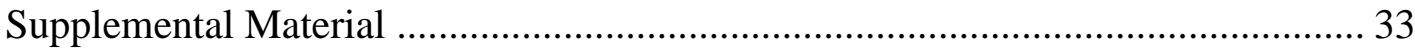

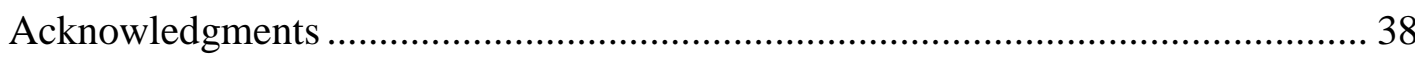

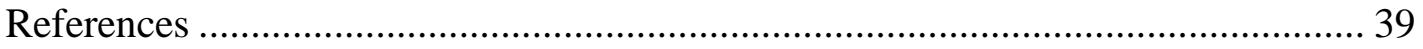

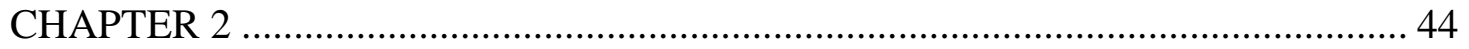

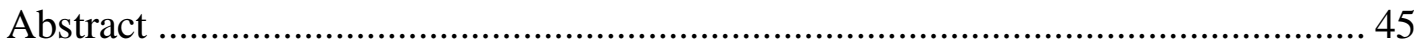

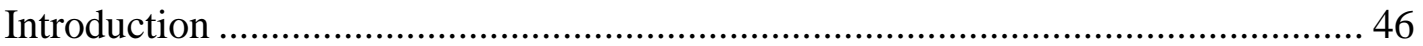

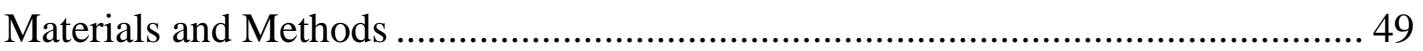

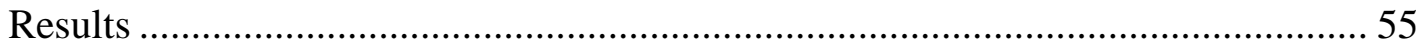

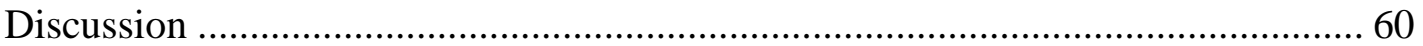

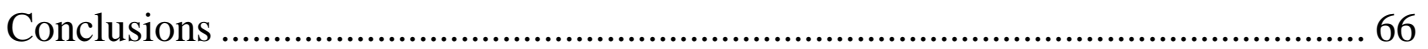

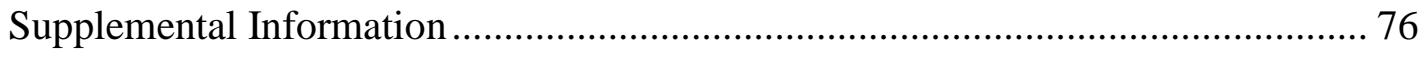




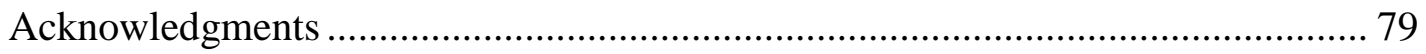

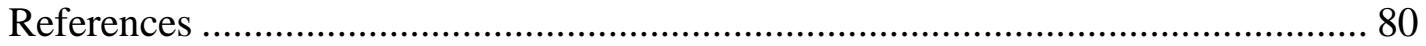

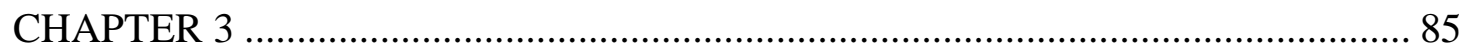

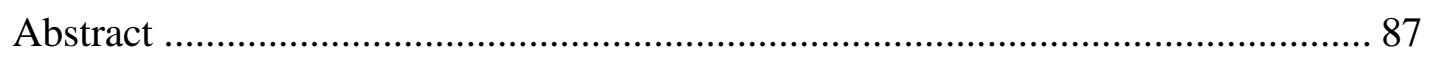

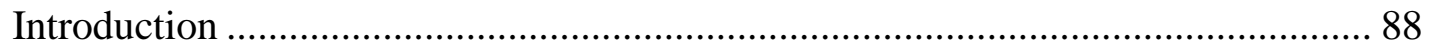

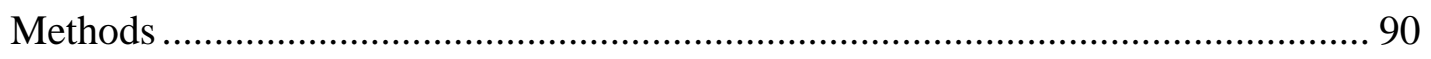

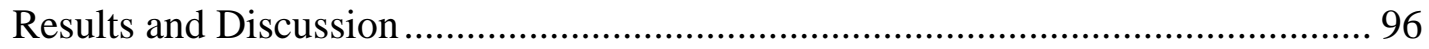

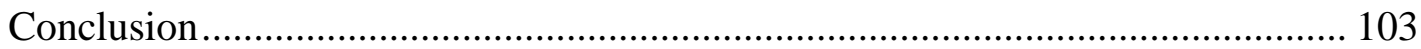

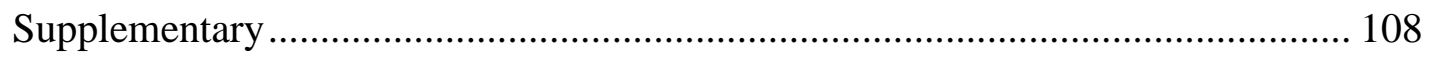

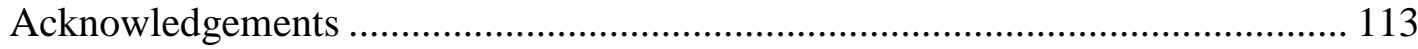

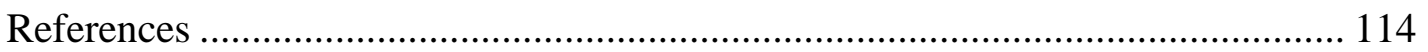

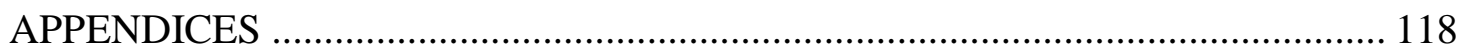

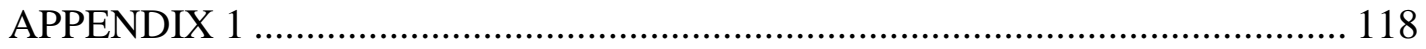

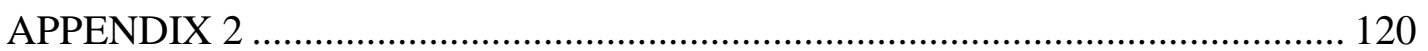

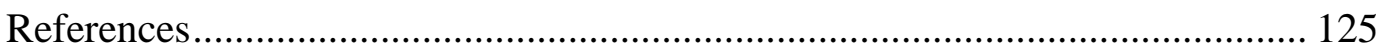

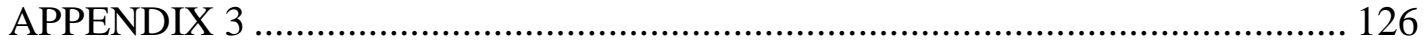

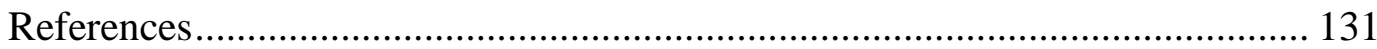

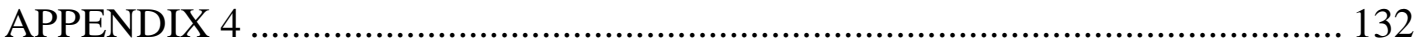

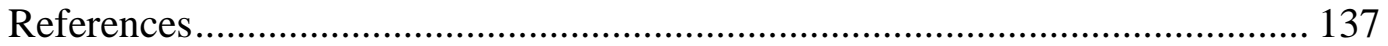

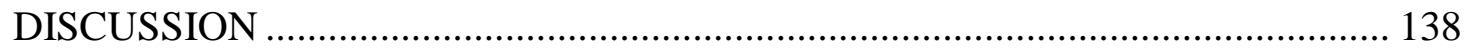




\section{LIST OF TABLES}

TABLE

PAGE

\section{Chapter 1}

Table 1. Outline of methods for objectives (obj.) 2 and 3 .26

Table 2. (A) Minimum detectable positive (or negative) slope (95\% confidence) for the Picarro and LGR. (B) Minimum detectable positive (or negative) slope for Shimadzu GC-2014 calculated using method similar to Christiansen et al. $(2015)$ 27

Table 3. Minimum detectable flux calculated from minimum detectable slope in Table 2 for a closure time of $120 \mathrm{~s}$ and averaging period $15 \mathrm{~s}$ for (A) lab mescosm experiments and (B) field measurements. For the Shimadzu GC-2014 a chamber closure time of 300s and no averaging period was

used 28

Table 4. Nitrous oxide fluxes calculated from Picarro and Shimadzu GC-2014 data from mesocosm A-1 and A-2. Fluxes with p-value $>0.05$ and/or with slopes below the detection limit are reported as "not determined" (ND) in the table. Normalized root mean square error (NRMSE) is also shown. Meas. \# is the measurement number in the series of chamber deployments. 
Supplemental Table 1. Methane and carbon dioxide fluxes calculated from Picarro and Shimadzu GC-2014 data from mesocosm A-1 and A-2. Fluxes with p-value $>0.05 \mathrm{and} /$ or with slopes below the detection limit are reported as "not determined" (ND) in the table. Normalized root mean square error (NRMSE) is also shown

\section{Chapter 2}

Table 1. Average and standard deviation of characteristics and operating conditions of Tank 1 of the IFAS BNR system during flux measurement dates. (A) Characteristics and operating conditions for which there is only one measurement location within the IFAS BNR tank. For all variables (except Total Nitrogen (TN) removed), data was collected every $10 \mathrm{sec}$. and the average for the morning hours during which flux measurements were made is shown. $\mathrm{WW}=$ wastewater DO=Dissolved Oxygen SVI=Sludge Volume Index (B) Data that was collected from same locations as flux measurements ( $\mathrm{n}=3$ for each zone). For variables that included data below the detection limit, the non-parametric Kaplan-Meier method was used to determine the mean and standard deviation 68

Table 2. Results of two way ANOVA and post hoc Tukey tests for each gas. Zones are abbreviated as Pre-Anoxic (AN1), IFAS (AR1), Post Anoxic (AN2), ReAeration (AR2). Seasons are abbreviated as Summer 2014 (S14), Fall (F), Winter (W), and Summer 2015 (S15). Letters indicate significant differences from Tukey HSD. Letters early in the alphabet indicate higher fluxes than letters later in the alphabet. 69 
Table 3. Breakdown of total greenhouse gas (GHG) emissions for Field's Point wastewater treatment plant.

Table S1. Results of two way ANOVA and post hoc Tukey tests for concentration of each dissolved gas. Zones are abbreviated as Pre-Anoxic (AN1), IFAS (AR1), Post Anoxic (AN2), Re-Aeration (AR2). Seasons are abbreviated as Summer 2014 (S14), Fall (F), Winter (W), and Summer 2015 (S15). Letters indicate significant differences from Tukey HSD. Letters early in the alphabet indicate higher fluxes than letters later in the alphabet

Table S2. Average production ( $\mathrm{kg}$ of $\operatorname{gas~}^{-1}$ ) and standard error for the year long measurements for each gas by zone

\section{Chapter 3}

Table S1. Primer sets used for qPCR analysis.

Table S2. Average and standard error of wastewater properties from pre-anoxic, aerated IFAS, post-anoxic, and re-aeration zones in the wastewater treatment plant and denitrification (SP1) and nitrification (SP2) compartments in Advantex, FAST, and SeptiTech (onsite wastewater treatment systems)

\section{Appendix 3}

Table 1. Range of reported site preference (SP) and bulk $\delta^{15} \mathrm{~N}$ for each potential source of $\mathrm{N}_{2} \mathrm{O}$ (Wunderlin et al. 2013) 


\section{LIST OF FIGURES}

FIGURE

PAGE

\section{Chapter 1}

Figure 1. (A) Allan standard deviation of the Picarro for $\mathrm{N}_{2} \mathrm{O}, \mathrm{CO}_{2}$, and $\mathrm{CH}_{4}$ showing measured data (dark colors) and Monte Carlo modeled data (light colors). The dashed gray lines indicate ideal $\tau^{-0.5}$ averaging of purely Gaussian (white) noise. The error bars indicate the variability of the modeled Allan standard deviation. For most data points, the error bars are smaller than the size of the symbols. (B) Allan standard deviation of the LGR for $\mathrm{N}_{2} \mathrm{O}$, showing measured data (dark triangles) and simulated data (gray triangles). The dashed line shows the white noise contribution with a dependence of $\tau^{-0.5}$, and the dot-dashed line shows the brown noise contribution with a dependence of I $\tau^{+0.5}$.

Figure 2. Picarro (black squares) and LGR (white squares) $\mathrm{N}_{2} \mathrm{O}$ fluxes from Mesocosm B-1 immediately after $\mathrm{N}$ addition (A) and $48 \mathrm{~h}$ later (B) and Mesocosm B-2 on both days (C). Each point represents one measurement and thus no standard error bars are show

Figure 3. Nitrous oxide flux from low $\mathrm{N}$ addition (A) and high $\mathrm{N}$ addition (B) field plots on each date. Each point represents a measurement and therefore no error bars are shown. Picarro fluxes are represented with black squares and LGR fluxes are represented with white squares 32 


\section{Chapter 2}

Figure 1. Aerial view of one of the ten Integrated Fixed Film Activated Sludge (IFAS) tanks at the Field's Point WWTP. The volume of each zone is reported in million gallons (MG) and the hydrologic retention time (HRT) is reported in hours. Rectangles represent locations of flux measurements and circles represent locations of water samples. Only one rectangle is shown in the Aerated IFAS Zone because all three flux measurements were collected from the same location.

Black bars represent barriers and water flow is from left to right 71

Figure 2. Average and standard error of (A) $\mathrm{N}_{2} \mathrm{O}$, (B) $\mathrm{CH}_{4}$, and (C) $\mathrm{CO}_{2}$ fluxes for each zone on each date. Zones are represented by different colors and seasons are represented by different shapes. 72

Figure 3. Significant regressions between gas fluxes. (A) $\mathrm{CH}_{4}$ and $\mathrm{CO}_{2}$ in Aerated IFAS and (B) $\mathrm{N}_{2} \mathrm{O}$ and $\mathrm{CO}_{2}$ in Pre-Anoxic 73

Figure 4. Average and standard error of (A) $\mathrm{N}_{2} \mathrm{O}$, (B) $\mathrm{CH}_{4}$, and (C) $\mathrm{CO}_{2}$ dissolved concentrations for each zone on each date. Zones are represented by different colors and seasons are represented by different shapes 74

Figure 5. PCA for $\mathrm{N}_{2} \mathrm{O}$ flux including data from all zones on all dates 75

Diagram S1. Production calculation 78 


\section{Chapter 3}

Figure 1. Nitrous oxide $\left(\mathrm{N}_{2} \mathrm{O}\right)$ fluxes (A), amoA abundance (B), and $n o s Z$ abundance (C) from pre-anoxic, aerated IFAS, post-anoxic, and re-aeration zones in the wastewater treatment plant (WWTP) and denitrification (SP1) and nitrification (SP2) compartments in Advantex, FAST, and SeptiTech (onsite wastewater treatment systems). Solid line in middle of box represents the median, edge of box represents $1^{\text {st }}$ and $3^{\text {rd }}$ quartile, and whiskers extend $1.5 \mathrm{x}$ the inter quartile range beyond the edge of the box............................... 104

Figure 2. Range of $\mathrm{N}_{2} \mathrm{O}$ emissions $\left(\mathrm{mg} \mathrm{N}_{2} \mathrm{O}\right.$ capita $\left.^{-1} \mathrm{~d}^{-1}\right)$ for each system as a whole (including all zones/compartments). Dashed line represents previously reported fluxes for WWTP examined in this study. For the WWTP there is a data point for each day of measurements $(n=2)$. For the OWTS, there is a data point for each house on each date that had significant emissions, Advantex $(n=4)$, SeptiTech $(\mathrm{n}=4)$, and FAST $(\mathrm{n}=6)$

Figure 3. Nucleic acid concentration from pre-anoxic, aerated IFAS, post-anoxic, and re-aeration zones in the wastewater treatment plant (WWTP) and denitrification (SP1) and nitrification (SP2) compartments in Advantex, FAST, and SeptiTech (onsite wastewater treatment systems). Solid line in middle of box represents the median, edge of box represents $1^{\text {st }}$ and $3^{\text {rd }}$ quartile, and whiskers extend $1.5 \mathrm{x}$ the inter quartile range beyond the edge of the box

Figure 4. amoA/nosz ratio from pre-anoxic, aerated IFAS, post-anoxic, and reaeration zones in the wastewater treatment plant (WWTP) and denitrification (SP1) and nitrification (SP2) compartments in Advantex, FAST, and SeptiTech 
(onsite wastewater treatment systems). Graph excludes one outlier (value $=16$ ) from post-anoxic zone of WWTP. Solid line in middle of box represents the median, edge of box represents $1^{\text {st }}$ and $3^{\text {rd }}$ quartile, and whiskers extend $1.5 \mathrm{x}$ the inter quartile range beyond the edge of the box....

\section{Appendix 1}

Figure 1. (A) $\mathrm{N}_{2} \mathrm{O}$, (B) $\mathrm{CH}_{4}$, and (C) $\mathrm{CO}_{2}$ fluxes from the re-aeration zone of the integrated fixed film activated sludge system at the Field's Point WWTP from 9:30 am to $3: 30 \mathrm{pm}$ on five different dates

\section{Appendix 2}

Figure 1. Simplified diagram of treatment train at Field's Point wastewater treatment plant. The figure shows only the components GHGs were measured from in this study

Figure 2. Average and standard error of three (A) $\mathrm{N}_{2} \mathrm{O}$, (B) $\mathrm{CO}_{2}$, and (C) $\mathrm{CH}_{4}$ flux measurements made in September 2016 from each additional component (grit chamber, primary clarifier, and secondary clarifier) at the Field's Point wastewater treatment plant. Average and standard error of flux measurements made from June 2014 - June 2015 (Chapter 2) from the (1) pre-anoxic, (2) aerated IFAS, (3) post-anoxic, and (4) re-aeration zones of one integrated fixed film activated sludge biological nitrogen removal tank. Fluxes that were not significant are reported as not detectable (ND) 


\section{Appendix 3}

Figure 1. (A) Site preference and (B) $\mathrm{N}_{2} \mathrm{O}$ fluxes from each zone on each date. ..130

\section{Appendix 4}

Figure 1. (A) Carbon Dioxide $\left(\mathrm{CO}_{2}\right)$ and methane $\left(\mathrm{CH}_{4}\right)$ from pre-anoxic, aerated IFAS, post-anoxic, and re-aeration zones in the wastewater treatment plant and denitrification (SP1) and nitrification (SP2) compartments in Advantex, FAST, and SeptiTech (onsite wastewater treatment systems). Solid line in middle of box represents the median, edge of box represents $1^{\text {st }}$ and $3^{\text {rd }}$ quartile, and whiskers extend $1.5 \mathrm{x}$ the inter quartile range beyond the edge of the box $\ldots \ldots \ldots \ldots \ldots \ldots 136$ 


\section{INTRODUCTION}

In Rhode Island (RI), there are two main types of wastewater treatment undergoing upgrades to include biological nitrogen removal (BNR): centralized WWTPs and onsite wastewater treatment systems (OWTS). Unfortunately, the resulting reduced nitrogen (N) loads to coastal ecosystems may come at the expense of increased greenhouse gas (GHG) emissions from the BNR systems. The central objective of this dissertation was to examine the magnitude, variability, and potential production mechanisms of GHG emissions from a BNR system at a WWTP and three types of advanced OWTS.

Three GHGs are of particular interest: nitrous oxide $\left(\mathrm{N}_{2} \mathrm{O}\right)$, carbon dioxide $\left(\mathrm{CO}_{2}\right)$, and methane $\left(\mathrm{CH}_{4}\right)$. Recent technological advancements have led to the first commercially available analyzer (Picarro G2508) capable of measuring all three of these GHGs $\left(\mathrm{N}_{2} \mathrm{O}, \mathrm{CO}_{2}\right.$, and $\left.\mathrm{CH}_{4}\right)$ nearly simultaneously in real time. Before using the analyzer at the wastewater treatment systems, Chapter 1 of this dissertation compares the ability of the Picarro G2508 to measure GHG emissions from salt marsh mesocosoms and field plots to two alternative methods (Los Gatos $\mathrm{N}_{2} \mathrm{O} / \mathrm{CO}$ and Shimadzu GC-2014).

Chapter 2 of this dissertation examines the temporal and spatial variability of $\mathrm{N}_{2} \mathrm{O}$, $\mathrm{CO}_{2}$, and $\mathrm{CH}_{4}$ emissions from one of the integrated fixed film activated sludge BNR tanks at the largest centralized WWTP in RI. Appendix 1 shows the hourly variation in the emissions of all three GHGs from one zone of the BNR tank examined in Chapter 2 and Appendix 2 compares the GHG emissions from the BNR tank to other components of the treatment train (grit tanks, primary clarifiers, and final clarifiers). Appendix 3 
investigates potential mechanisms of the $\mathrm{N}_{2} \mathrm{O}$ emissions from the $\mathrm{BNR}$ tank at the centralized WWTP using isotopomers.

In Chapter 3 and Appendix 4, the emissions of all three GHGs from the BNR tank at the centralized WWTP are compared to those from advanced OWTS designed to remove N. In addition, the abundance of a nitrifying (amoA) and denitrifying (nosZ) gene are compared among the systems in order to investigate potential mechanisms of the $\mathrm{N}_{2} \mathrm{O}$ emissions.

This research is timely as BNR systems will increasingly be used at both WWTPs and OWTS as the human population continues to grow. As a result, the need for efficient $\mathrm{N}$ removal systems that successfully remove $\mathrm{N}$ with minimal greenhouse gas emissions will continue to grow. 


\section{References}

Galloway, J., J. Aber, J. Erisman, S. Seitzinger, R. Howarth, E. Cowling, and J. Cosby. 2003. The Nitrogen Cascade. BioScience 53(4): 341-356.

Roman, C.T., N. Jaworski, F.T. Short, S. Findlay, and R.S. Warren. 2000. Estuaries of the northeastern United States: Habitat and land use signatures. Estuaries 23(6): 743-764. 


\section{CHAPTER 1}

\section{EVALUATION OF LASER-BASED SPECTROMETERS FOR GREENHOUSE GAS FLUX MEASUREMENTS IN COASTAL MARSHES}

\section{Published as:}

Brannon, E.Q.; Moseman-Valtierra, S.; Rella, C.; Martin, R.; Chen, X.; Tang, J. (2016). Evaluation of laser-based spectrometers for greenhouse gas flux measurements in coastal marshes. Limnology and Oceanography: Methods; 14, 466476.

Keywords: Cavity-ring down spectroscopy (CRDS); Fertilization; Methane $\left(\mathrm{CH}_{4}\right)$; Nitrous oxide $\left(\mathrm{N}_{2} \mathrm{O}\right)$; Wetlands 


\section{$\underline{\text { Abstract }}$}

Precise and rapid analyses of greenhouse gases (GHGs) will advance understanding of the net climatic forcing of coastal marsh ecosystems. We examined the ability of a cavity ring down spectroscopy (CRDS) analyzer (Model G2508, Picarro Inc.) to measure carbon dioxide $\left(\mathrm{CO}_{2}\right)$, methane $\left(\mathrm{CH}_{4}\right)$, and nitrous oxide $\left(\mathrm{N}_{2} \mathrm{O}\right)$ fluxes in real-time from coastal marshes through comparisons with a Shimadzu GC-2014 (GC) in a marsh mesocosm experiment and with a similar laser-based $\mathrm{N}_{2} \mathrm{O}$ analyzer (Model $\mathrm{N}_{2} \mathrm{O} / \mathrm{CO}$, Los Gatos Research, Inc.) in both mesocosm and field experiments. Minimum (analytical) detectable fluxes for all gases were more than one order of magnitude lower for the Picarro than the GC. In mesocosms, the Picarro analyzer detected several $\mathrm{CO}_{2}, \mathrm{CH}_{4}$, and $\mathrm{N}_{2} \mathrm{O}$ fluxes that the $\mathrm{GC}$ could not, but larger $\mathrm{N}_{2} \mathrm{O}$ fluxes (218-409 $\left.\mu \mathrm{mol} \mathrm{m} \mathrm{m}^{-2} \mathrm{hr}^{-1}\right)$ were similar between analyzers. Minimum detectable fluxes for the Picarro were 1 order of magnitude higher than the Los Gatos analyzer for $\mathrm{N}_{2} \mathrm{O}$. The Picarro and Los Gatos $\mathrm{N}_{2} \mathrm{O}$ fluxes $\left(3-132 \mu \mathrm{mol} \mathrm{m}^{-2} \mathrm{hr}^{-1}\right)$ differed in two mesocosm nitrogen addition experiments, but were similar in a mesocosm with larger $\mathrm{N}_{2} \mathrm{O}$ fluxes (326-491 $\left.\mu \mathrm{mol} \mathrm{m}^{-2} \mathrm{hr}^{-1}\right)$. In a field comparison, Picarro and Los Gatos $\mathrm{N}_{2} \mathrm{O}$ fluxes $\left(13 \pm 2 \mu \mathrm{mol} \mathrm{m}^{-2} \mathrm{hr}^{-1}\right)$ differed in plots receiving low nitrogen loads but were similar in plots with higher nitrogen loads and fluxes roughly double in magnitude. Both the Picarro and Los Gatos analyzers offer efficient and precise alternatives to GC-based methods, but the former uniquely enables simultaneous measurements of three major GHGs in coastal marshes. 


\section{Introduction}

Human activity has significantly increased atmospheric concentrations of three principal greenhouse gases (GHGs) that drive global climate change: carbon dioxide $\left(\mathrm{CO}_{2}\right)$, methane $\left(\mathrm{CH}_{4}\right)$, and nitrous oxide $\left(\mathrm{N}_{2} \mathrm{O}\right)$ (Forster et al. 2007; LeTreut et al. 2007). Although they have received less attention than $\mathrm{CO}_{2}$ in climate policy, even relatively small increases in emissions of $\mathrm{CH}_{4}$ and $\mathrm{N}_{2} \mathrm{O}$ may have large effects on global climate change because of their large global warming potentials per molecule, 21 and 310 respectively (Solomon et al. 2007).

Recent approaches to ameliorate rising GHG concentrations in the atmosphere have included efforts to both reduce anthropogenic sources and to enhance GHG uptake and storage in natural ecosystems that serve as overall GHG sinks (Mcleod et al. 2011). Coastal ecosystems including mangroves, salt marshes, and seagrasses contribute to global carbon (C) sequestration at particularly high rates (84-233 Tg C

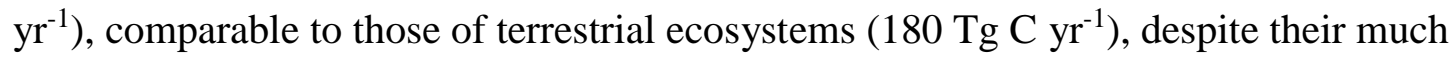
smaller area (Mcleod et al. 2011). Coastal ecosystems not only have the ability to store large amounts of $\mathrm{C}$, but studies have indicated that unlike peatlands, these wetlands have negligible $\mathrm{CH}_{4}$ and $\mathrm{N}_{2} \mathrm{O}$ emissions due to the high sulfate concentration of seawater, and high salinity, saturation and anoxia of sediment (Mitsch and Gosselink 2000; Chmura et al. 2003; Poffenbarger et al. 2011). However, because fluxes can have large spatial and temporal variability related to shifts in temperature, tidal and diel light cycles, and estuarine flood gradients (Bartlett et al. 1987; Hirota et al. 2007; Liikanen et al. 2009; Tong et al. 2010) and disturbances such as nutrient loading may promote emissions of $\mathrm{CH}_{4}$ and $\mathrm{N}_{2} \mathrm{O}$ at rates sufficient to offset significant 
portions of $\mathrm{CO}_{2}$ uptake (Liu and Greaver 2009), real time, continuous GHG measurements on all three gases $\left(\mathrm{CO}_{2}, \mathrm{CH}_{4}\right.$ and $\left.\mathrm{N}_{2} \mathrm{O}\right)$ simultaneously is desirable in order to accurately estimate the net climatic forcing of the ecosystem.

Most studies of GHG fluxes in coastal ecosystems have historically relied on analyzing discrete air samples collected from a field flux chamber on a laboratory gas chromatograph (GC), but there are several disadvantages associated with this approach (reviewed in Rapson and Dacres 2014). High precision infrared (IR) technology, including cavity ring-down spectrometry (CRDS) and off-axis integrated cavity output spectroscopy (OA-ICOS), now allow the opportunity for more sensitive, rapid, and continuous GHG measurements. Infrared spectrometers can be used to measure GHGs at a sensitivity 500 times better than that of a GC and at a frequency of up to 20 $\mathrm{Hz}$ (Hensen et al. 2013). Infrared technology relies on the fact that different gases absorb IR light at unique wavelengths (Hensen et al. 2013). CRDS is a near-IR method employed in the first commercially available analyzer that simultaneously analyzes $\mathrm{CO}_{2}, \mathrm{CH}_{4}$, and $\mathrm{N}_{2} \mathrm{O}$ (Model G2508, Picarro, Inc., Santa Clara, CA, USA; hereafter referred to as Picarro). In CRDS, a tunable near-IR laser is directed into an optical cavity consisting of two or more highly reflecting mirrors, leading to a long sample path length on the order of $10 \mathrm{~km}$. The absorbance of the sample is determined from the measurement of the decay time of the light in the cavity (Crosson 2008). In OA-ICOS, which is used in a commercially available $\mathrm{N}_{2} \mathrm{O}$ and $\mathrm{CO}$ analyzer (Model $\mathrm{N}_{2} \mathrm{O} / \mathrm{CO}$, Los Gatos Research, Inc., Mountain View, CA, USA; hereafter referred to as LGR), a mid-IR laser is tuned to wavelengths of interest while 
generating a high density of traverse cavity modes. Then, absorbance is used to determine gas concentrations.

Analyzers utilizing the OA-ICOS and CRDS technologies are now emerging in GHG studies in coastal ecosystems. Mortazavi et al. (2013) have used an OA-ICOSbased analyzer to measure $\mathrm{CH}_{4}$ fluxes from a Spartina alterniflora dominated marsh in Alabama and determined that over a two day deployment period, $\mathrm{CH}_{4}$ fluxes varied by nearly an order of magnitude (72 to $396 \mu \mathrm{mol} \mathrm{CH}_{4} \mathrm{~m}^{-2} \mathrm{hr}^{-1}$ ). In addition, Martin and Moseman-Valtierra (2015) used the Picarro analyzer (CRDS technology) to compare $\mathrm{CO}_{2}, \mathrm{CH}_{4}$ and $\mathrm{N}_{2} \mathrm{O}$ fluxes between invasive Phragmites australis and native high marsh vegetation in New England salt marshes that spanned a salinity gradient. No $\mathrm{N}_{2} \mathrm{O}$ fluxes were detected and $\mathrm{CH}_{4}$ emissions were a small fraction of the high $\mathrm{CO}_{2}$ uptake rates observed ( -25 to $-54 \mu \mathrm{mol} \mathrm{CO} \mathrm{CO}_{2}^{-2} \mathrm{~h}^{-1}$ ). As more studies begin to take advantage of these new technologies, it is important to compare their abilities to measure GHG fluxes in coastal ecosystems with those of established techniques. Only a few studies have attempted to compare CRDS or OA-ICOS IR analyzers with GC based techniques and both of these studies were agricultural based (Christiansen et al. 2015; Gelfand et al. 2015).

The goal of this research is to assess the ability of the Picarro CRDS analyzer to measure GHG fluxes from coastal marshes. Our specific objectives are: (1) to determine minimum (analytical) detection limits for gases analyzed by the Picarro and compare them to those for a Shimadzu GC-2014 $\left(\mathrm{CO}_{2}, \mathrm{CH}_{4}\right.$, and $\left.\mathrm{N}_{2} \mathrm{O}\right)$ and LGR analyzer (OA-ICOS technology, $\mathrm{N}_{2} \mathrm{O}$ only); In doing so, we investigate impacts of chamber closure times and data averaging period on detection limits for the Picarro 
and LGR; (2) to compare $\mathrm{CO}_{2}, \mathrm{CH}_{4}$, and $\mathrm{N}_{2} \mathrm{O}$ fluxes measured in static chambers with the Shimadzu GC-2014 and Picarro (Table 1, Mesocosm experiment A); and (3) to compare $\mathrm{N}_{2} \mathrm{O}$ fluxes measured in static chambers with the Picarro and LGR analyzers in a mesocosm (Table 1, Mesocosm experiment B) and a field experiment (Table 1).

\section{Materials and procedures}

\section{Objective 1: Minimum detection limits}

Gas fluxes were calculated from linear rates of change in gas concentrations within a closed chamber as described in Martin and Moseman-Valtierra (2015) and Supplemental Materials. We primarily report detection limits as the slope of gas concentration versus time in units of $\mathrm{ppb} \mathrm{s}^{-1}$ to preserve generality and refer to them hereafter as "minimum detectable slopes."

Analyzers

Both the Picarro and LGR report gas concentrations (as dry mole fractions in ppm) roughly every 2 seconds. All default settings were maintained for the Picarro and more information about the CRDS technology used can be found in Fleck et al. (2013). The LGR was factory calibrated by measuring known standards (NOAA CMDL primary standard for $\mathrm{N}_{2} \mathrm{O}$ and $\mathrm{CO}$, and a LICOR 610 dewpoint generator for the water vapor calibration). 


\section{Monte Carlo simulations for detection limits of Picarro and LGR}

To estimate the minimum detectable slope of each gas $\left(\mathrm{CO}_{2}, \mathrm{CH}_{4}\right.$, and $\mathrm{N}_{2} \mathrm{O}$ for the Picarro, and only $\mathrm{N}_{2} \mathrm{O}$ for the LGR), we first measured and then modeled (using Monte Carlo simulations) Allan standard deviations based on instrument noise levels (Allan 1966) (for details see Supplemental Materials). Modeled and measured Allan standard deviations for both instruments are shown in Figure 1, with good agreement indicating that the models adequately represents instrument noise. The Picarro has an Allan standard deviation at 5 minutes of $0.4 \mathrm{ppb}, 400 \mathrm{ppb}$, and $0.09 \mathrm{ppb}$ (1sigma) for $\mathrm{N}_{2} \mathrm{O}, \mathrm{CO}_{2}$, and $\mathrm{CH}_{4}$, respectively. The LGR has an Allan standard deviation at 5 minutes of $0.045 \mathrm{ppb}$ for $\mathrm{N}_{2} \mathrm{O}$.

A second Monte Carlo simulation was then performed for each analyzer to determine the minimum detectable slopes employing similar methods as Parkin et al. (2012). This analysis encompasses only the instrument noise and drift; systematic effects due to the chamber itself are not captured in this simulation. In this simulation, the flux in the chamber was set to zero. The slope of the simulated concentration data vs. time was determined from a simple linear least squares fit. Monte Carlo iterations were generated to compute the upper and lower bounds of the slope distributions, which represents the values between which $90 \%$ of the Monte Carlo estimates of the slope lie. Detection limits were identified using cumulative distribution functions for these modeled slopes at the 0.05 probability level (Parkin et al. 2012). For each combination of averaging period (from 5 to $120 \mathrm{~s}$ ) and chamber deployment time (120 and 360s) 1000 Monte Carlo iterations were performed. 


\section{Shimadzu GC-2014 method quantification limit}

The precision of the Shimadzu GC-2014 was determined as outlined in Christiansen et al. (2015). A low standard containing concentrations of $\mathrm{CO}_{2}(319.6$ ppm), $\mathrm{CH}_{4}(2.625 \mathrm{ppm})$ and $\mathrm{N}_{2} \mathrm{O}(0.519 \mathrm{ppm})$ was read 20 times and the precision was defined as the method quantification limit (standard deviation $\times 3 \times \mathrm{t} 99 \%$ ). The resulting precision was $265 \mathrm{ppm}$ for $\mathrm{CO}_{2}, 1.6 \mathrm{ppm}$ for $\mathrm{CH}_{4}$, and 0.14 ppm for $\mathrm{N}_{2} \mathrm{O}$. To calculate the minimum detectable slope, the precision was divided by the chamber closure time (5 minutes).

\section{Objective 2: Shimadzu GC-2014 vs. Picarro comparison}

\section{Mesocosm Experiment A}

To compare $\mathrm{CO}_{2}, \mathrm{CH}_{4}$, and $\mathrm{N}_{2} \mathrm{O}$ fluxes measured by the Picarro and Shimadzu GC-2014, an experiment using two distinct mesocosms (Mesocosm IDs: A-1 and A-2, Table 1) with coastal marsh plants and/or soils was performed. These mesocosms were selected based on prior observations of contrasting $\mathrm{CO}_{2}, \mathrm{CH}_{4}$, and $\mathrm{N}_{2} \mathrm{O}$ fluxes (R.M. Martin and S.M. Moseman-Valtierra unpubl.). Soils and/or plants for both mesocosms were extracted $\left(0.03 \mathrm{~m}^{2}\right.$ area and $0.0047 \mathrm{~m}^{3}$ volume $)$ with a soil knife and shovel from a salt marsh in Jamestown, RI and transferred to $18 \mathrm{~cm}$ (diameter) x 18 $\mathrm{cm}$ (height) pots. Nitrogen $(\mathrm{N})$ in the form of ammonium nitrate was applied to Mesocosm A-1 in an effort to produce a wide range of $\mathrm{N}_{2} \mathrm{O}$ fluxes (Table 1). For more details on conditions of mesocosms prior to gas flux measurements see Table 1 and Supplemental Materials. 
As the objective of this study was to compare the Shimadzu GC-2014 and Picarro analyzers, and not to specifically contrast the different soils, replication was obtained by making multiple gas measurements simultaneously with both instruments on each mesocosm. Each mesocosm constituted a time series of measurements each separated by one minute (sufficient time for the analyzer and open chamber to return to ambient concentrations). Therefore, each flux measurement in this series was considered a separate replicate.

\section{Gas flux measurements}

Static flux chambers were used to simultaneously measure $\mathrm{CO}_{2}, \mathrm{CH}_{4}$, and $\mathrm{N}_{2} \mathrm{O}$ fluxes with the Picarro and Shimadzu GC-2014. For each measurement, an intact soil mesocosm was transferred in a pot to a 5 gallon bucket that was then covered with a transparent static flux chamber (Table 1). A closed-cell polyethylene foam collar and plastic wrap were used to make a gas-tight seal between the rim of the bucket and the chamber. The chamber contained two battery-powered fans to mix the interior gases. A coiled stainless steel tube (inner diameter of $0.71 \mathrm{~mm}$ ) attached to a port at the top of the chamber maintained equilibrium with atmospheric pressure. The duration of chamber deployments ( $5 \mathrm{~min}$.) was based on observed periods of linear changes in gas concentrations (Table 1$)$. Nylon tubing $(0.46 \mathrm{~cm}$ inner diameter and approximately 5 $\mathrm{m}$ in total length) connected to the Picarro via two gas-tight ports in a closed loop. The total system volume for the Picarro (chamber, tubing, analyzer, and bucket) and Shimadzu GC-2014 (chamber and bucket) was $3.74 \times 10^{-2}$ and $3.72 \times 10^{-2} \mathrm{~m}^{3}$ respectively. 
The chamber also had an extra port with stopcock by which discrete gas samples were manually collected and analyzed on the Shimadzu GC-2014. Gas samples $(35 \mathrm{~mL})$ were drawn by hand into $60 \mathrm{~mL}$ nylon syringes equipped with LuerLok stopcocks at $0,0.5,1,1.5,2,3,4$, and 5 minutes. Gas samples were transferred to pre-evacuated glass vials (Exetainers, Labco Inc.) within 24 hours of collection and stored underwater. The samples were analyzed on the Shimadzu GC-2014 within 2 months. Lengthy storage was required due to unanticipated and prolonged instrument repairs. Prior tests have demonstrated an average of $18 \%$ gas loss over a month and a half time period (data not included). Gas chromatography methods are described in Supplemental Material. Three specialty gas standards (Airgas, Billerica MA) were used to calibrate the Shimadzu GC-2014 daily with concentrations ranging from 2.6 ppm to $50.0 \mathrm{ppm}$ for $\mathrm{CH}_{4}, 320.0 \mathrm{ppm}$ to $15,100.0 \mathrm{ppm}$ for $\mathrm{CO}_{2}$, and $0.6 \mathrm{ppm}$ to 10.1 ppm for $\mathrm{N}_{2} \mathrm{O}$.

For data collected with the Picarro, the first 30 seconds of measurements (4.5 minutes remaining) were not included in the flux calculations in order to account for gases passing through the length of the tubing between the analyzer and the chamber. Since collection of discrete gas samples did not require tubing, the entire 5 minutes of data (8 data points) were included in calculations of fluxes from samples analyzed on the Shimadzu GC-2014. 


\section{Objective 3: LGR vs. Picarro comparison}

\section{Objective 3: Mesocosm Experiment B}

Marsh mesocosms for Objective 3 (Mesocosm IDs B-1 and B-2, Table 1) received a larger range of $\mathrm{N}$ additions than those used for Objective 2. Soil and/or plant samples $\left(0.03 \mathrm{~m}^{2}\right.$ area and $0.0047 \mathrm{~m}^{3}$ volume $)$ were collected from a salt marsh in Narragansett, RI with a soil knife and transferred on ice to the laboratory in a Ziploc bag. At the lab the mesocosms were transferred to an $18 \mathrm{~cm}$ (height) $\mathrm{x} 18 \mathrm{~cm}$ (diameter) pot (one pot per sample).

Nitrous oxide fluxes were measured for each mesocosm on two dates separated by 48 hours because the change in emissions over time enabled comparison of the analyzers over a wide range of $\mathrm{N}_{2} \mathrm{O}$ fluxes. On each date, a series of flux measurements was made (separated by at least 1 minute) on each mesocosm (Table 1). Nitrogen levels (ammonium chloride and ammonium nitrate) were applied iteratively in this experiment to each mesocosm in an effort to produce a wide range of $\mathrm{N}_{2} \mathrm{O}$ fluxes (Table 1).

Gas fluxes were measured as described above (Objective 2) except for the following changes: no discrete gas samples were collected and nylon tubing (approximately $7 \mathrm{~m}$ for each analyzer) ran from gas-tight ports at the top of the chamber to the Picarro and LGR analyzers in parallel so that measurements were made by the two analyzers simultaneously. The total system volume for the Picarro and LGR (chamber, tubing, analyzer, and bucket) was $3.74 \times 10^{-2}$ and $3.77 \times 10^{-2} \mathrm{~m}^{3}$ respectively. Air temperature inside the chamber was monitored with a Hobo® pendant temperature logger (Onset Inc.). 


\section{Objective 3: Field experiment}

Nitrous oxide fluxes were measured with the LGR and Picarro in response to two levels of experimental $\mathrm{N}$ additions in a salt marsh on two dates (July and August 2014) at Sage Lot Pond in Waquoit Bay, MA (Table 1). Sage Lot Pond has a plant composition that is representative of a southern New England salt marsh and is located in the Waquoit Bay National Estuarine Research Reserve. Due to its location within the reserve, the watershed surrounding this marsh receives minimal anthropogenic $\mathrm{N}$ loadings (McClelland and Valiela 1998).

For the $\mathrm{N}$ addition, square steel collars $(56 \mathrm{~cm} \times 56 \mathrm{~cm})$ were placed in two groups of three collars ( 6 collars total). Each collar was at least 1.3 meters from the next one in a given group and the different groups were spaced at least $11 \mathrm{~m}$ from each other in a line that ran parallel to the shoreline. These were installed 2 years prior to the gas flux measurements. In order to avoid cross-contamination of plots by $\mathrm{N}$ additions, all three plots in a given group were assigned one of the $\mathrm{N}$ treatments in the form of sodium nitrate (Table 1). The assigned $\mathrm{N}$ treatment was diluted in $4 \mathrm{~L}$ of seawater and applied as evenly as possible to the plot surface with a watering can approximately one hour before flux measurements took place. This $\mathrm{N}$ manipulation is part of a larger study that will test $\mathrm{N}_{2} \mathrm{O}$ flux responses over multiple spatio-temporal scales (J. Tang et al. unpubl.). Our goal with this study, in contrast, was to compare the $\mathrm{N}_{2} \mathrm{O}$ fluxes measured by the two analyzers on a subset of dates (Table 1) that were representative of the larger data set.

Nitrous oxide fluxes were measured by placing a transparent chamber (Table 1) with weather stripping on the bottom to create a gas-tight seal on each collar for 4.5 
minutes. For data collected from both the Picarro and LGR, the first 30 seconds of measurements (4 min. remaining) were not included in the flux calculation to account for the length of tubing between the chamber and the two analyzers. The chamber contained two battery-powered fans to mix the interior gases. Air and soil temperature inside the chamber was monitored with a Hobo® Pro v2 (U23-00x) temperature logger (Onset Inc., Bourne, Massachusetts). The chamber and analyzers were connected as outlined for Mesocosm Experiment B, only $13.5 \mathrm{~m}$ of tubing was used

for each analyzer. The total system volume for the Picarro and LGR (chamber, tubing, analyzer, and bucket) was $1.95 \times 10^{-2} \mathrm{~m}^{3}$.

\section{Statistics}

The statistical significance of each gas flux was determined using a sequential three step approach based on (1) visual inspection of data for any obvious measurement errors, (2) a test of the significance of regressions for linear periods of gas changes over time, and (3) application of slope detection limits to all fluxes with statistically significant regressions. In this study, removal of points occurred for one flux. If the regression was not significant ( $p$-value $>0.05$ ), then the flux was classified as not determined (ND). If the regression was significant (p-value $<0.05)$ then we compared the flux to the slope detection limit determined in Objective 1. Fluxes with significant regressions and that exceeded the slope detection limit were defined as significant. Fluxes below the slope detection limit were classified as ND even if the regression was significant. Fluxes labeled as ND were excluded from statistical analysis. 
In addition, the normalized root mean square error (NRMSE) was calculated for each significant flux as outlined in Christiansen et al. (2011) and used as a metric to compare the precision of analyzers. Although $\mathrm{R}^{2}$ has been used in previous literature, the NRMSE is not subjective to the range of the data and can therefore be used to compare the precision of the analyzers more objectively.

A paired t-test was used to determine if there was a significant difference between Picarro and Shimadzu GC-2014 fluxes (Objective 2). This was possible only for $\mathrm{N}_{2} \mathrm{O}$ in mesocosm A-1 because in most cases the Shimadzu GC-2014 did not detect significant fluxes (Table 2, Supplemental Material Table 1).

A paired t-test was also used to determine if Picarro and LGR $\mathrm{N}_{2} \mathrm{O}$ fluxes in laboratory mesocosms significantly differed (Objective 3). Two paired t-tests were used for Mesocosm B-1: one test for data immediately after the experimental N addition when small fluxes were observed and one test for data collected two days later when much larger $\mathrm{N}_{2} \mathrm{O}$ fluxes were observed. The separate analyses facilitated comparison of the analyzers over those distinct $\mathrm{N}_{2} \mathrm{O}$ flux ranges. The range of fluxes for Mesocosm B-2 were smaller and as a result a single paired t-test was used. To compare field Picarro and LGR $\mathrm{N}_{2} \mathrm{O}$ fluxes (Objective 3), data from each date was combined and a paired t-test was performed for each $\mathrm{N}$ addition level.

A significance level of 0.05 was applied to all statistical analyses. Data were checked for normality using the Shapiro-Wilk test. All statistics were performed in $\mathrm{JMP}^{\circledR}$ (Version 11. SAS Institute Inc., Cary, NC, 1989-2007), R Core Team (2013) or Matlab (2012). 


\section{Assessment}

\section{Objective 1: Minimum detection limits}

Table 2A summarizes the minimum detectable slope bounds (in units of $\mathrm{ppb} \mathrm{s}^{-1}$ ) for different chamber closure times and averaging periods that were determined based on the second Monte Carlo simulation for both the Picarro and LGR analyzer (applying the noise model). Table 2B reports the minimum detectable slope for five minutes for the Shimadzu GC-2014. We primarily report detection limits as the slope of gas concentration versus time in units of $\mathrm{ppb} \mathrm{s}^{-1}$ to preserve generality and refer to them as "minimum detectable slopes." To later compare these detection limits to published values, we convert them into units of moles per unit area per unit time based on our specific chamber dimensions and average air temperatures in lab or field experiments as described in Martin and Moseman-Valtierra (2015) and Supplemental materials (Table $3 \mathrm{~A}$ and $\mathrm{B}$ ).

For both the Picarro and LGR, the averaging period has essentially no effect on the minimum detectable slope (Table 2A). Therefore, for flux calculations with Picarro and LGR data a 15 second average was used. Minimum detectable slope improved for both analyzers with an increase in chamber closure time (see Supplemental material for more details). Based on these results, approximately 5 minutes of data were used for Picarro and LGR flux calculations in subsequent experiments. The use of a 15 second average and 4-5 minutes of data resulted in 1620 data points for each Picarro and LGR flux calculation. 


\section{Objective 2: Shimadzu GC-2014 vs. Picarro comparison}

In mesocosm experiment A, we compared the Picarro and Shimadzu GC-2014 across two ranges of $\mathrm{N}_{2} \mathrm{O}$ fluxes differing by greater than one order of magnitude (Table 4). Large $\mathrm{N}_{2} \mathrm{O}$ fluxes were measured from Mesocosm A-1 (containing Nenriched soil) and smaller $\mathrm{N}_{2} \mathrm{O}$ fluxes were measured from Mesocosm A-2 (soil containing Phragmites australis) (Table 4). At the higher range of $\mathrm{N}_{2} \mathrm{O}$ fluxes (Mesocosm A-1), Picarro and Shimadzu GC-2014 fluxes did not significantly differ ( $t=1.00, p=0.42, \mathrm{df}=2$ ) and ranged from 218 to $409 \mu \mathrm{mol} \mathrm{m}^{-2} \mathrm{hr}^{-1}$ (Table 4). At the lower range of $\mathrm{N}_{2} \mathrm{O}$ fluxes (Mesocosm A-2) all three Picarro $\mathrm{N}_{2} \mathrm{O}$ fluxes were significant $\left(14 \pm 1 \mu \mathrm{mol} \mathrm{m}^{-2} \mathrm{~h}^{-1}\right)$ while none of the Shimadzu GC-2014 $\mathrm{N}_{2} \mathrm{O}$ fluxes for this mesocosm were above the detection limit (Table 4).

Unfortunately, the majority of the $\mathrm{CH}_{4}$ and $\mathrm{CO}_{2}$ fluxes were below the detection limit of the Shimadzu GC-2014 and as a result could not be determined (Supplementary Material Table 1). Methane fluxes detected by the Picarro ranged from 1 to $4604 \mu \mathrm{mol} \mathrm{m}{ }^{-2} \mathrm{hr}^{-1}$ but only one of these fluxes was above the detection limit of the Shimadzu GC-2014 (Supplementary Material Table 1). All of the $\mathrm{CO}_{2}$ fluxes were below the detection limit of the Shimadzu GC-2014 but the range measured by the Picarro was 1.8 to $31.6 \mu \mathrm{mol} \mathrm{m}^{-2} \mathrm{~s}^{-1}$ (Supplementary Material Table $1)$. 


\section{Objective 3: Picarro, LGR comparison of $\mathrm{N}_{2} \mathrm{O}$ measurements}

\section{Objective 3: Mesocosm Experiment B}

With both the Picarro and LGR analyzers, significant $\mathrm{N}_{2} \mathrm{O}$ fluxes were observed from two mesocosms with emissions varying from $7-491 \mu \mathrm{mol} \mathrm{m}{ }^{-2} \mathrm{hr}^{-1}$ (Mesocosm B-1) and 3-91 $\mu \mathrm{mol} \mathrm{m}^{-2} \mathrm{hr}^{-1}$ (Mesocosm B-2). During the first round of measurements for Mesocosm B-1 when fluxes were relatively small $\left(61 \pm 10 \mu \mathrm{mol} \mathrm{m} \mathrm{m}^{-2}\right.$ $\mathrm{hr}^{-1}$ ), $\mathrm{N}_{2} \mathrm{O}$ fluxes from the Picarro were on average $13 \%$ higher than for the LGR (Figure 2A) and this small difference was statistically significant $(t=-5.47, p<0.05$, $\mathrm{df}=8$ ). However, $\mathrm{N}_{2} \mathrm{O}$ fluxes for the Picarro and LGR were not significantly different during the second round of measurements 48 hours later $(t=1.30, p=0.23, \mathrm{df}=8$, Figure 2B) when fluxes were larger $\left(356 \pm 21 \mu \mathrm{mol} \mathrm{m}^{-2} \mathrm{hr}^{-1}\right)$. Nitrous oxide fluxes from the Picarro and LGR from Mesocosm B-2 were relatively small $\left(38 \pm 8 \mu \mathrm{mol} \mathrm{m}^{-2} \mathrm{hr}^{-1}\right)$ and there was a small but significant difference, $(t=-2.44, p=0.04, \mathrm{df}=9$, Figure $2 \mathrm{C})$. Similar to Mesocosm B-1, the fluxes from the Picarro were on average $12 \%$ higher than for the LGR (Figure 2A and 2C).

\section{Objective 3: Field experiment}

Significant $\mathrm{N}_{2} \mathrm{O}$ fluxes were observed from both the Picarro and LGR analyzers in all $\mathrm{N}$ enrichment plots. There was a small $\left(1.09 \mu \mathrm{mol} \mathrm{m} \mathrm{m}^{-2} \mathrm{hr}^{-1}\right)$ but significant difference in $\mathrm{N}_{2} \mathrm{O}$ fluxes ( 8 to $23 \mu \mathrm{mol} \mathrm{m}^{-2} \mathrm{hr}^{-1}$ ) between analyzers measured from the low $\mathrm{N}$ enrichment plots $\left(0.7 \mathrm{~g} \mathrm{~N} \mathrm{~m}^{-2}\right)$ on both dates $(t=3.47$, $p=0.040, \mathrm{df}=3$, Figure 3). Nitrous oxide fluxes measured from the high $\mathrm{N}$ enrichment 
plots $\left(1.4 \mathrm{~g} \mathrm{~N} \mathrm{~m}^{-2}\right)$ ranged from 18 to $43 \mu \mathrm{mol} \mathrm{m} \mathrm{mr}^{-1}$ and were similar between analyzers on both dates $(t=1.27, p=0.260, \mathrm{df}=5$, Figure 3$)$.

\section{$\underline{\text { Discussion }}$}

\section{Comparing the suite of three GHGs: $\mathrm{CO}_{2}, \mathrm{CH}_{4}, \mathrm{~N}_{2} \mathrm{O}$}

CRDS technology in the Picarro confers several advantages over GC approaches for the quantification of GHG fluxes in dynamic coastal ecosystems. First, the Picarro had 1-3 orders of magnitude lower analytical detection limits for $\mathrm{CO}_{2}, \mathrm{CH}_{4}$, and $\mathrm{N}_{2} \mathrm{O}$ (Tables 2 and 3) than the Shimadzu GC-2014 and greater precision as evident in the consistently lower NRMSE values of the Picarro (Table 4). Indeed, the Picarro was consistently able to detect $\mathrm{CO}_{2}$ and $\mathrm{CH}_{4}$ fluxes as small as $2 \mu \mathrm{mol} \mathrm{m}{ }^{-2} \mathrm{~s}^{-1}$ and $1 \mu \mathrm{mol}$ $\mathrm{m}^{-2} \mathrm{hr}^{-1}$ respectively from the salt marsh mesocosms, which were below the detection limit of the Shimadzu GC-2014 over the chamber duration time that we employed (5 minutes) (Supplementary Materials). Recent comparisons of GC and CRDS methods (with the Picarro G2508 model) using soils from forests, agricultural fields, and wetlands have similarly found lower detection rates for $\mathrm{CH}_{4}$ for $\mathrm{GC}$ methods compared to the Picarro (Christiansen et al. 2015). The similarity of Picarro and Shimadzu GC-2014 $\mathrm{N}_{2} \mathrm{O}$ fluxes on the high end of the observed ranges (304 \pm 52 and $265 \pm 25 \mu \mathrm{mol} \mathrm{N} \mathrm{O} \mathrm{m}^{-2} \mathrm{~h}^{-1}$, respectively) is consistent with findings by Christiansen et al. (2015). Although we were not able to draw comparisons with smaller fluxes, due to low detection rates, Christiansen et al. (2015) found a GC and Picarro to be comparable in soils with much smaller $\mathrm{N}_{2} \mathrm{O}$ fluxes (about $7 \mu \mathrm{mol} \mathrm{N}_{2} \mathrm{O} \mathrm{m}^{-2} \mathrm{~h}^{-1}$ ) and 
were likely able to detect smaller $\mathrm{N}_{2} \mathrm{O}$ fluxes with the $\mathrm{GC}$ due to longer chamber closure time periods.

In comparing the Shimadzu GC-2014 and Picarro, we selected relatively short time periods (approximately 4-5 $\mathrm{min}$ ) because they were clearly sufficient to observe linear changes in gas concentrations with the Picarro and LGR analyzers and have been applied in recent field studies (Martin and Moseman-Valtierra 2015). Although longer chamber closure times certainly would increase GC detection rates, preliminary trials revealed that $\mathrm{CH}_{4}$ and $\mathrm{CO}_{2}$ fluxes from mesocosms with chamber closure times of 30 minutes were still below the detection limit of the Shimadzu GC-2014 by an order of magnitude (Brannon and Moseman-Valtierra unpub. data). However, when chamber closure times were increased to 30 minutes, significant Shimadzu GC-2014 $\mathrm{N}_{2} \mathrm{O}$ fluxes were detected on the order of $70 \mu \mathrm{mol} \mathrm{N} \mathrm{N}_{2} \mathrm{O} \mathrm{m} \mathrm{h}^{-2}$ and were comparable to those measured by the Picarro (Brannon and Moseman-Valtierra unpub. data). Further, the short chamber closure periods offered by high-precision, in situ analyzers, such as the Picarro and LGR, enables researchers to limit many of the errors associated with longer chamber closure times, such as alterations of the gas diffusion gradient and increases in temperature and represents a significant technological advancement (Davidson et al. 2002).

\section{Measurements of $\mathrm{N}_{2} \mathrm{O}$ - comparing Picarro and LGR}

In both lab and field experiments, the $\mathrm{N}_{2} \mathrm{O}$ fluxes measured by the Picarro and LGR were generally similar despite the differences in technology (Figure 2 and 3). However, in some mesocosms (first round of Mesocosm B-1 measurements and 
Mesocosm B-2) and in field plots with low $\mathrm{N}$ additions, when fluxes were relatively low (3-132 $\left.\mu \mathrm{mol} \mathrm{m} \mathrm{mr}^{-2}\right)$, the Picarro fluxes were slightly larger than LGR fluxes (9 13\%). This discrepancy may have partially been due to the low sample size, as no difference was found between the analyzers for $\mathrm{N}_{2} \mathrm{O}$ fluxes from the high $\mathrm{N}$ field plots for which the range of $\mathrm{N}_{2} \mathrm{O}$ fluxes (18-43 $\mu \mathrm{mol} \mathrm{m}^{-2} \mathrm{hr}^{-1}$ ) overlap with those from Mesocosm B-1 (on first date), Mesocosm B-2, and the low N enriched plot. The differences in IR regions used by the analyzers (nearIR for the Picarro and mid-IR for the LGR) may also partially explain this discrepancy. In one of these mesocosms (B1, Figure $2 \mathrm{~A}$ ) consecutive measurements resulted in increasing flux values, potentially due to a lag in response to $\mathrm{N}$ additions. However, this is unlikely to have altered the comparison of analyzers because there was no relationship between the difference in fluxes from the two analyzers and measurement number (data not shown). To further discern the cause of such small but consistent differences between the two analyzers, further work including direct inter-calibration would be helpful.

Based on published $\mathrm{N}_{2} \mathrm{O}$ fluxes in coastal marsh ecosystems, ranging from 1.4 to 14.8 $\mu \mathrm{mol} \mathrm{m}^{-2} \mathrm{hr}^{-1}$ (Allen et al. 2007; Hirota et al. 2007; Liikanen et al. 2009; Moseman-Valtierra et al. 2011), the Picarro and LGR will generally be able to detect low $\mathrm{N}_{2} \mathrm{O}$ fluxes. The minimum detectable fluxes for the field chamber used in this study for the Picarro was $1.7 \mu \mathrm{mol} \mathrm{m}^{-2} \mathrm{hr}^{-1}$ while for the LGR it was $0.1 \mu \mathrm{mol} \mathrm{m}{ }^{-2} \mathrm{hr}^{-1}$. One tradeoff for the higher detection limit of the Picarro however is the unique ability of the Picarro to simultaneously measure all three important GHGs, which is particularly advantageous as these gases are highly variable in space and time (Bartlett 
et al. 1985; Robinson et al. 1998; Bange 2006) and disturbance-induced $\mathrm{CH}_{4}$ and $\mathrm{N}_{2} \mathrm{O}$ fluxes can potentially offset $\mathrm{CO}_{2}$ uptake (Liu and Greaver 2009).

The significant advantage of high precision IR GHG analyzers, such as the Picarro and LGR, in coastal biogeochemistry is that they allow for rapid quantification of real time GHG data and this comes at a time when there is strong need to develop better climate change models that can include potential climate feedbacks from coastal ecosystems. Analyzers like the Picarro and LGR are significantly advancing scientists' abilities to better understand how anthropogenic stressors have the potential to change the GHG budget of coastal ecosystems.

\section{Comments and recommendations}

Several practical benefits are obtained from the rapid, real-time data collection of in situ gas analyzers such as the Picarro and LGR. Disadvantages of the Shimadzu GC-2014 include long run times and limited numbers of samples as well as substantially higher detection limits. However, the real time measurements collected by analyzers such as the Picarro and LGR facilitate identification of experimental errors (such as rapid changes in gas concentration and pressure resulting from disturbance associated with chamber placement) allowing the user to repeat measurements when needed. This is a clear advantage over grab sample based GCmethods.

Both the Picarro and LGR are sensitive to water and therefore must be operated with caution in coastal environments. Even small amounts of moisture in the analyzers' cavities may condense on the mirrors and lead to costly repairs. Further, 
the user must be aware that on warm days humidity may increase rapidly in the chamber during deployment. Fortunately, the Picarro monitors moisture and alerts the user if the moisture reaches a set threshold. In addition, the Picarro has two hydrophobic membrane filters in the inlet sample system that traps stray water droplets before they reach the sensitive optical cavity. One solution to this problem is to switch the inlet and outlet tubing if the moisture begins to rise. Moisture traps may also be devised relatively simply and employed if more humid conditions require further intervention. With proper attention to basic logistical needs, the Picarro and LGR offer significantly improved capabilities for GHG measurements from coastal environments. 
Table 1. Outline of methods for objectives (obj.) 2 and 3.

\begin{tabular}{|c|c|c|c|c|c|c|c|c|c|c|}
\hline & & & & Chamber & & Chamber & & Total N & & \\
\hline $\begin{array}{l}\text { Obj. } \\
\#\end{array}$ & $\begin{array}{l}\text { Methods } \\
\text { Compared }\end{array}$ & Gases & $\begin{array}{c}\text { Experiment } \\
\text { ID }\end{array}$ & $\begin{array}{l}\text { Height } \\
(\mathrm{cm})\end{array}$ & $\begin{array}{l}\text { Chamber } \\
\text { Material }\end{array}$ & $\begin{array}{l}\text { Duration } \\
\text { (min.) }\end{array}$ & $\begin{array}{l}\text { Mesocosm } \\
\text { ID }\end{array}$ & $\begin{array}{l}\text { Addition } \\
\left(\mathrm{g} \mathrm{N} \mathrm{m}^{-2}\right)\end{array}$ & $\begin{array}{l}\text { Dominant } \\
\text { Species }\end{array}$ & $\begin{array}{c}\text { \# of } \\
\text { meas. }\end{array}$ \\
\hline \multirow[t]{3}{*}{2} & $\mathrm{GC}$ and & $\mathrm{CO}_{2}$ & Mesocosm & 36 & Polycarbonate & 5 & A-1 & 19.7 & Unvegetated & 3 \\
\hline & Picarro & $\mathrm{CH}_{4}$ & Experiment & & & & & & Soil & (total) \\
\hline & & $\mathrm{N}_{2} \mathrm{O}$ & A & & & & A-2 & - & $\begin{array}{l}\text { Phragmites } \\
\text { australis }\end{array}$ & $\begin{array}{c}3 \\
\text { (total) }\end{array}$ \\
\hline \multirow[t]{4}{*}{3} & $\begin{array}{l}\text { Picarro } \\
\text { and LGR }\end{array}$ & $\mathrm{N}_{2} \mathrm{O}$ & $\begin{array}{l}\text { Mesocosm } \\
\text { Experiment }\end{array}$ & 36 & Polycarbonate & 5 & B-1 & 105.0 & $\begin{array}{l}\text { Spartina } \\
\text { patens }\end{array}$ & $\begin{array}{c}9 \\
\text { (twice) }\end{array}$ \\
\hline & & & B & & & & B-2 & 136.9 & $\begin{array}{l}\text { Unvegetated } \\
\text { Soil }\end{array}$ & $\begin{array}{c}10 \\
\text { (total) }\end{array}$ \\
\hline & & & $\begin{array}{l}\text { Field } \\
\text { Experiment }\end{array}$ & 56 & Acrylic & 4.5 & Low & 0.7 & $\begin{array}{l}\text { Spartina } \\
\text { alterniflora }\end{array}$ & $\begin{array}{c}4 \\
\text { (total) }\end{array}$ \\
\hline & & & & & & & High & 1.4 & $\begin{array}{l}\text { Spartina } \\
\text { alterniflora }\end{array}$ & $\begin{array}{c}6 \\
\text { (total) }\end{array}$ \\
\hline
\end{tabular}


Table 2: (A) Minimum detectable positive (or negative) slope (95\% confidence) for the Picarro and LGR. (B) Minimum detectable positive (or negative) slope for A. Picarro and LGR

\begin{tabular}{|c|c|c|c|c|c|c|}
\hline \multirow{2}{*}{$\begin{array}{l}\text { Chamber } \\
\text { Closure } \\
\text { Time (s) }\end{array}$} & \multirow[b]{2}{*}{$\begin{array}{l}\text { Averaging } \\
\text { period (s) }\end{array}$} & \multicolumn{3}{|l|}{ Picarro } & \multirow{2}{*}{\multicolumn{2}{|c|}{$\begin{array}{l}\text { LGR } \\
\mathrm{N}_{2} \mathrm{O} \\
(\mathrm{ppb} / \mathrm{s})\end{array}$}} \\
\hline & & $\begin{array}{l}\mathrm{N}_{2} \mathrm{O} \\
(\mathrm{ppb} / \mathrm{s})\end{array}$ & $\begin{array}{l}\mathrm{CO}_{2} \\
(\mathrm{ppb} / \mathrm{s})\end{array}$ & $\begin{array}{l}\mathrm{CH}_{4} \\
(\mathrm{ppb} / \mathrm{s})\end{array}$ & & \\
\hline \multirow{3}{*}{120} & 5 & $2.4 \times 10^{-2}$ & 28.3 & $4.2 \times 10^{-3}$ & & $8.1 \times 10^{-4}$ \\
\hline & 15 & $2.3 \times 10^{-2}$ & 28.3 & $4.0 \times 10^{-3}$ & & $7.9 \times 10^{-4}$ \\
\hline & 30 & $2.4 \times 10^{-2}$ & 28.3 & $4.0 \times 10^{-3}$ & & $7.7 \times 10^{-4}$ \\
\hline \multirow{5}{*}{360} & 5 & $4.5 \times 10^{-3}$ & 5.1 & $8.8 \times 10^{-4}$ & & $2.9 \times 10^{-4}$ \\
\hline & 15 & $4.5 \times 10^{-3}$ & 5.3 & $9.0 \times 10^{-4}$ & & $3.1 \times 10^{-4}$ \\
\hline & 30 & $4.5 \times 10^{-3}$ & 5.3 & $8.9 \times 10^{-4}$ & & $3.1 \times 10^{-4}$ \\
\hline & 60 & $4.4 \times 10^{-3}$ & 5.1 & $8.9 \times 10^{-4}$ & & $3.1 \times 10^{-4}$ \\
\hline & 120 & $4.6 \times 10^{-3}$ & 5.7 & $9.1 \times 10^{-4}$ & & $3.1 \times 10^{-4}$ \\
\hline
\end{tabular}

B. Shimadzu GC-2014

\begin{tabular}{lllll}
\hline Chamber & Averaging & $\mathrm{N}_{2} \mathrm{O}$ & $\mathrm{CO}_{2}$ & $\mathrm{CH}_{4}$ \\
Closure & period (s) & $(\mathrm{ppb} / \mathrm{s})$ & $(\mathrm{ppb} / \mathrm{s})$ & $(\mathrm{ppb} / \mathrm{s})$ \\
Time (s) & & & & \\
\hline 300 & NA & 0.5 & 882 & 5 \\
\hline
\end{tabular}


Table 3. Minimum detectable flux calculated from minimum detectable slope in Table 2 for a closure time of 120 seconds and averaging period 15 seconds for (A) lab mesocosm experiments and (B) field measurements. For the Shimadzu GC- 2014 a chamber closure time of 300 seconds and no averaging period was used.

A. Lab

\begin{tabular}{llll}
\hline Analyzer & $\mathrm{N}_{2} \mathrm{O}$ & $\mathrm{CH}_{4}$ & $\mathrm{CO}_{2}$ \\
& $\mu \mathrm{mol} \mathrm{m} \mathrm{hr}^{-1}$ & $\mu \mathrm{mol} \mathrm{m}^{-2} \mathrm{hr}^{-1}$ & $\mu \mathrm{mol} \mathrm{m}^{-2} \mathrm{~s}^{-1}$ \\
\hline Shimadzu GC-2014 & 103.6 & 1036.2 & 50.8 \\
Picarro & 4.8 & 1.6 & 1.1 \\
LGR & 0.2 & $\mathrm{NA}$ & $\mathrm{NA}$ \\
\hline
\end{tabular}

B. Field Shimadzu GC-2014 calculated using method similar to Christiansen et al. 2015.

\begin{tabular}{ll}
\hline Analyzer & $\mathrm{N}_{2} \mathrm{O}$ \\
& $\mu \mathrm{mol} \mathrm{m}^{-2} \mathrm{hr}^{-1}$ \\
\hline Picarro & 1.7 \\
LGR & 0.1 \\
\hline
\end{tabular}


Table 4. Nitrous oxide fluxes calculated from Picarro and Shimadzu GC-2014 data from mesocosm A-1 and A-2. Fluxes with p-value $>0.05$ and/or with slopes below the detection limit are reported as "not determined" (ND) in the table. Normalized root mean square error (NRMSE) is also shown. Meas. \# is the measurement number in the series of chamber deployments.

\begin{tabular}{|c|c|c|c|c|c|c|c|c|c|c|c|}
\hline \multirow{2}{*}{$\begin{array}{l}\text { Meso } \\
\text {-cosm }\end{array}$} & \multirow{2}{*}{$\begin{array}{c}\text { Meas. } \\
\quad \#\end{array}$} & \multicolumn{5}{|l|}{ Picarro } & \multicolumn{5}{|l|}{ GC } \\
\hline & & $\begin{array}{c}\text { p- } \\
\text { value }\end{array}$ & NRMSE & $\mathrm{R}^{2}$ & $\begin{array}{l}\text { Slope } \\
\text { (ppb/s) }\end{array}$ & $\begin{array}{c}\text { Flux } \\
\left(\mu \mathrm{mol} \mathrm{m}{ }^{-2} \mathrm{~h}^{-1}\right)\end{array}$ & $\begin{array}{c}\text { Flux } \\
\left(\mu \mathrm{mol} \mathrm{m}{ }^{-2} \mathrm{~h}^{-1}\right)\end{array}$ & $\begin{array}{l}\text { Slope } \\
(\mathrm{ppb} / \mathrm{s})\end{array}$ & $\mathrm{R}^{2}$ & NRMSE & $\mathrm{p}$-value \\
\hline \multirow{3}{*}{ A-1 } & 1 & $<0.05$ & 0.05 & 0.98 & 1.98 & 409 & 301 & 1.46 & 0.71 & 0.16 & $<0.05$ \\
\hline & 2 & $<0.05$ & 0.01 & 1.00 & 1.21 & 251 & 277 & 1.35 & 0.86 & 0.31 & $<0.05$ \\
\hline & 3 & $<0.05$ & 0.01 & 1.00 & 1.22 & 252 & 218 & 1.06 & 0.83 & 0.13 & $<0.05$ \\
\hline \multirow{3}{*}{ A-2 } & 1 & $<0.05$ & 0.10 & 0.84 & 0.07 & 13 & ND & -0.03 & 0.00 & 1.02 & 0.90 \\
\hline & 2 & $<0.05$ & 0.08 & 0.94 & 0.07 & 15 & ND & -0.35 & 0.02 & 0.34 & 0.74 \\
\hline & 3 & $<0.05$ & 0.10 & 0.88 & 0.06 & 12 & $\mathrm{ND}$ & 0.11 & 0.01 & 0.39 & 0.85 \\
\hline
\end{tabular}


(a) Picarro

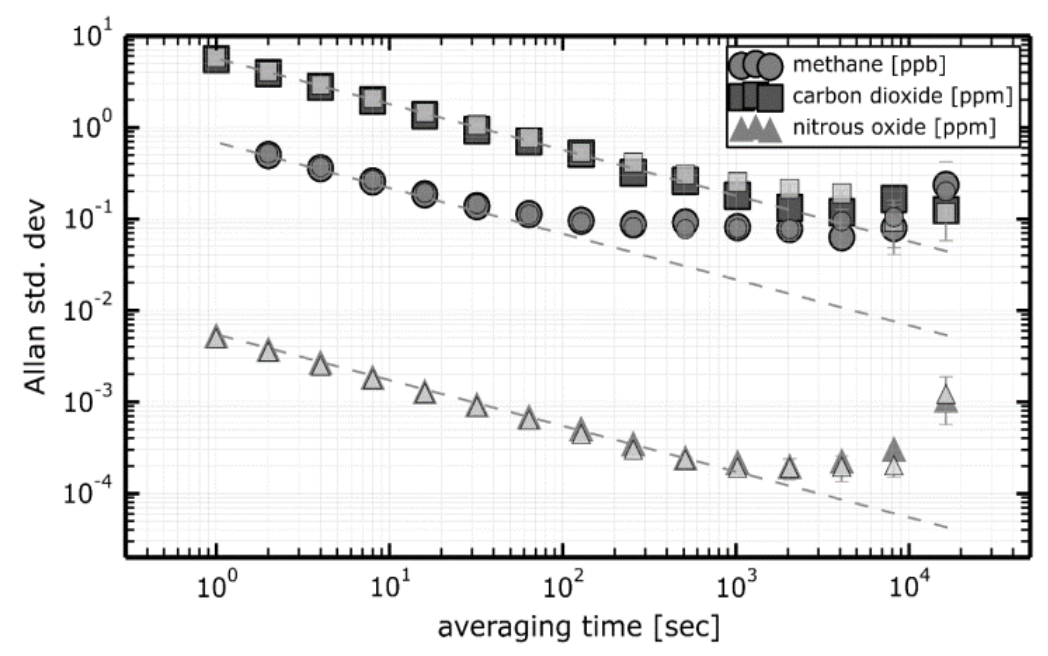

(b) LGR

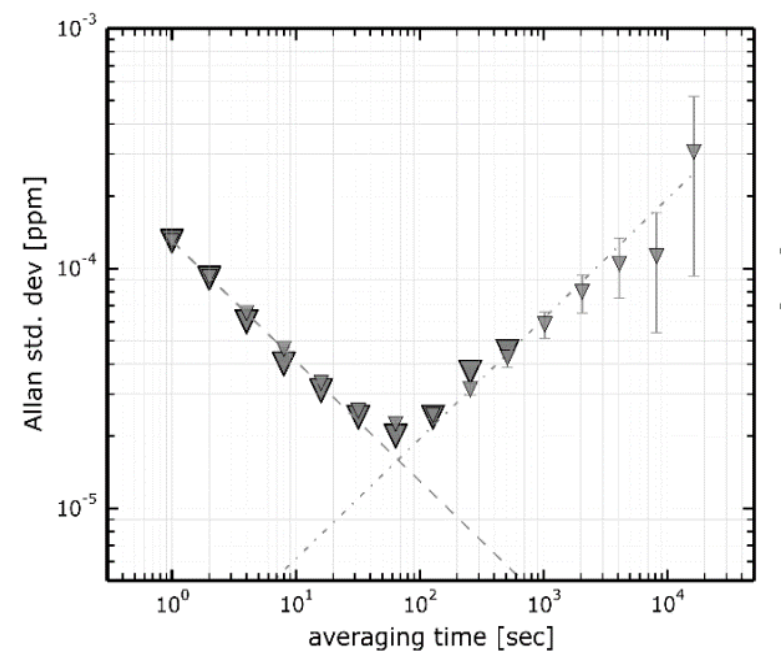

Figure 1: (A) Allan standard deviation of the Picarro for $\mathrm{N}_{2} \mathrm{O}, \mathrm{CO}_{2}$, and $\mathrm{CH}_{4}$ showing measured data (dark colors) and Monte Carlo modeled data (light colors). The dashed gray lines indicate ideal $\tau^{-0.5}$ averaging of purely Gaussian (white) noise. The error bars indicate the variability of the modeled Allan standard deviation. For most data points, the error bars are smaller than the size of the symbols. (B) Allan standard deviation of the LGR for $\mathrm{N}_{2} \mathrm{O}$, showing measured data (dark triangles) and simulated data (gray triangles). The dashed line shows the white noise contribution with a dependence of $\tau^{-0.5}$, and the dotdashed line shows the brown noise contribution with a dependence of $1 \tau^{+0.5}$. 
(a) B-1 Immediately after $\mathrm{N}$ addition

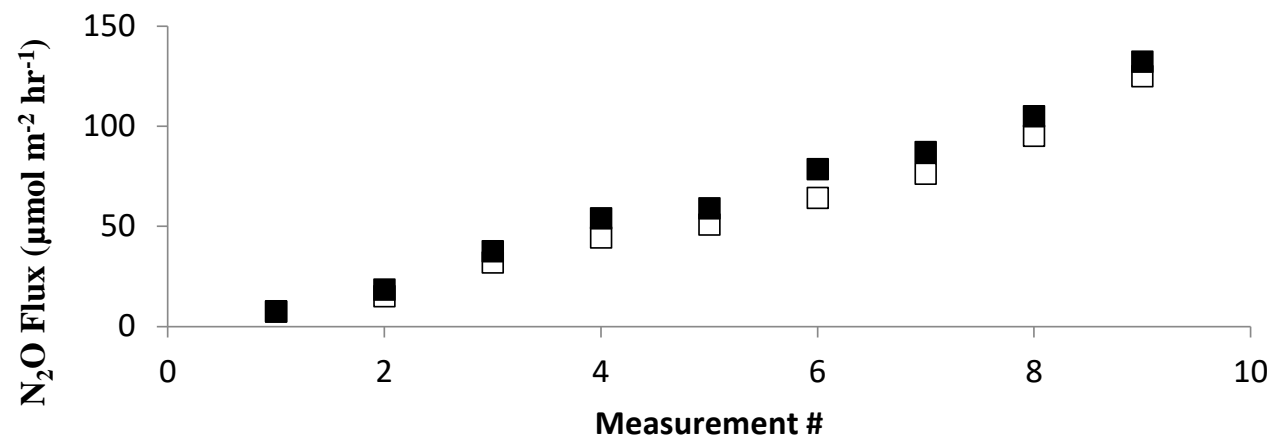

(b) B-1 Two days after $\mathrm{N}$ addition

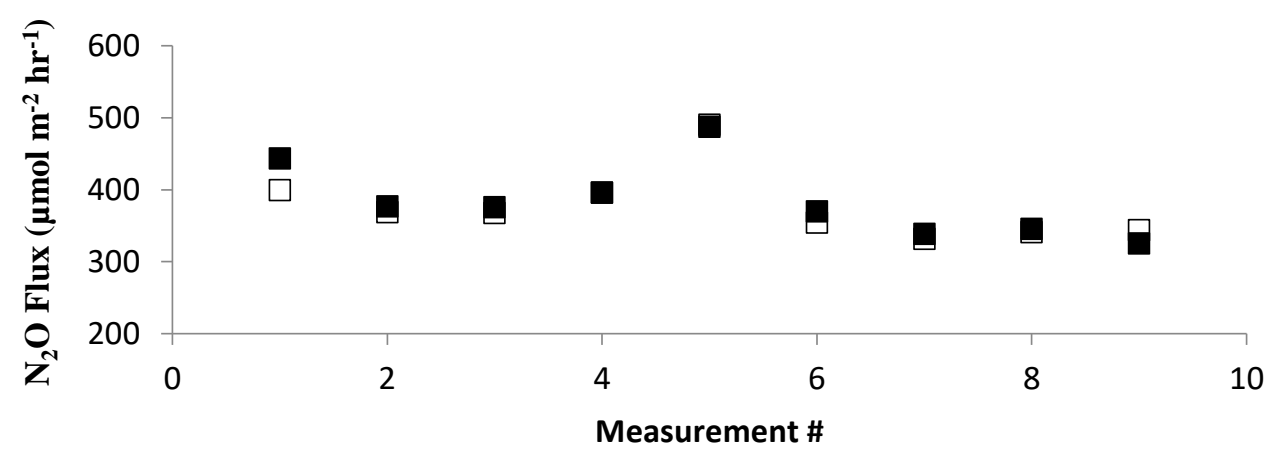

(c) B-2

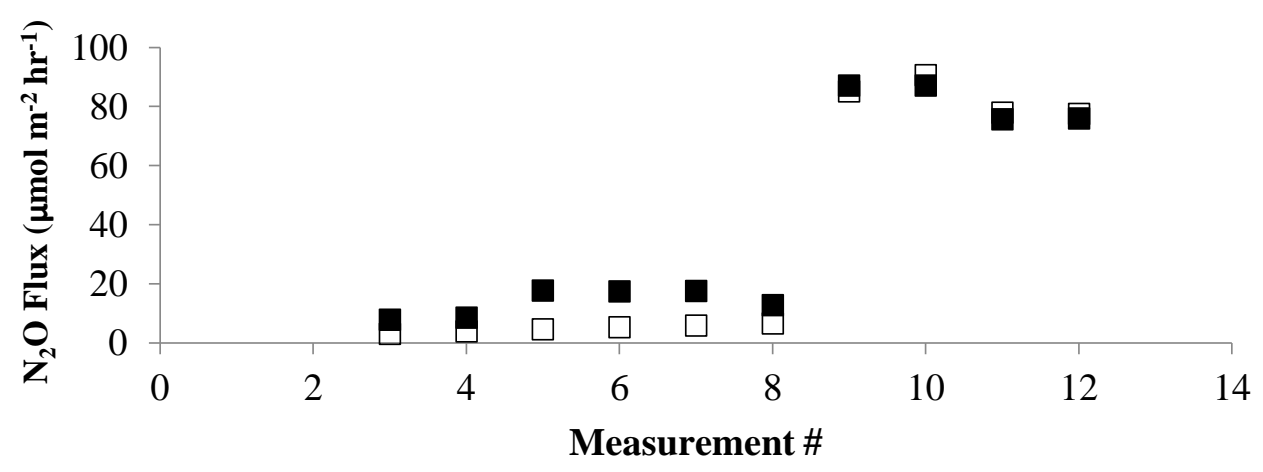

Figure 2. Picarro (closed squares) and LGR (open squares) $\mathrm{N}_{2} \mathrm{O}$ fluxes from Mesocosm B-1 immediately after $\mathrm{N}$ addition (A) and 48 hours later (B) and Mesocosm B-2 on both days (C). Each point represents one measurement and thus no standard error bars are shown. 
(A) Low $\mathrm{N}$ adition

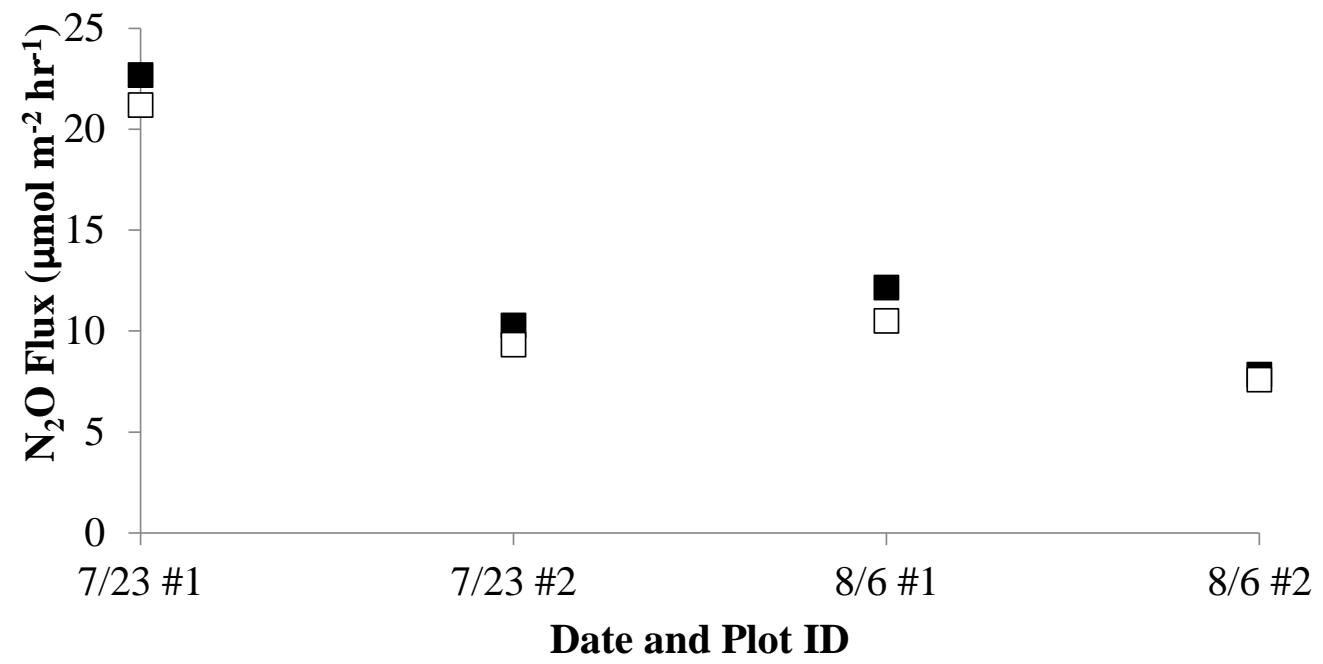

(B) High $\mathrm{N}$ addition

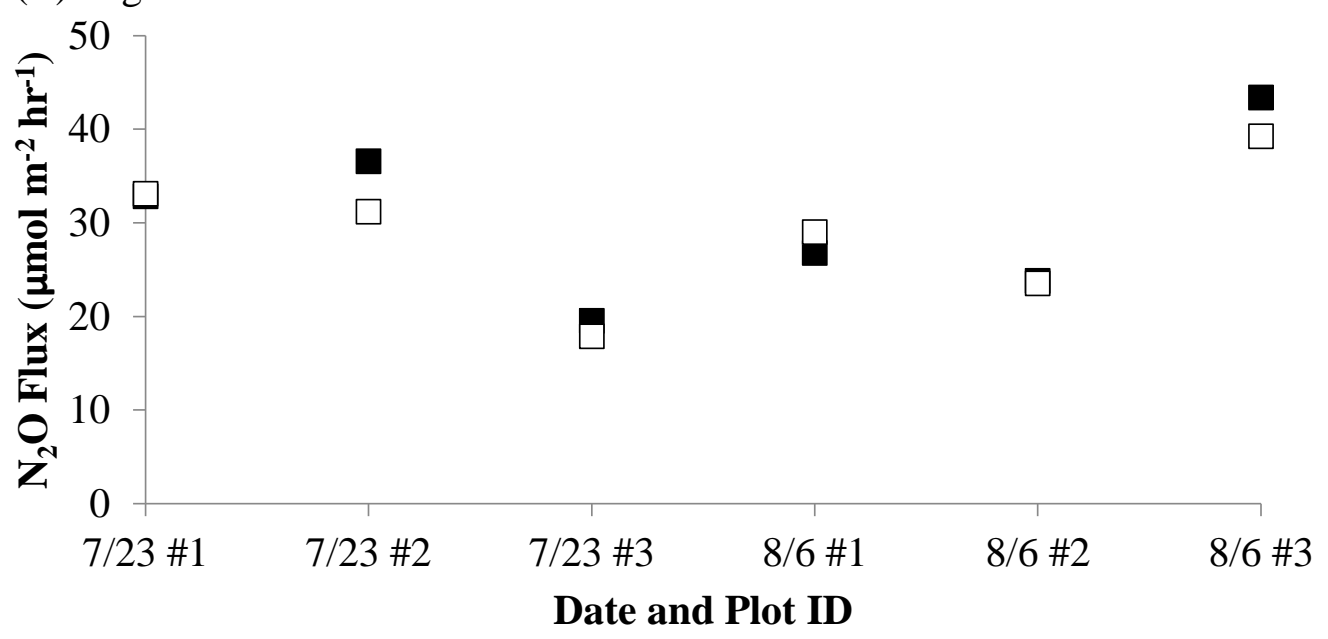

Figure 3. Nitrous oxide flux from low $\mathrm{N}$ addition (A) and high $\mathrm{N}$ addition (B) field plots on each date. Each point represents a measurement and therefore no error bars are shown. Picarro fluxes are represented with black squares and LGR fluxes are represented with white squares 


\section{Supplemental Material}

\section{Gas Flux Calculations}

Gas fluxes were calculated from the linear periods of change in gas concentrations in the chamber over time (dC/dt) using the ideal gas law (Eq. 1). $\mathrm{F}=\mathrm{dC} / \mathrm{dt}(\mathrm{PV} / \mathrm{RAT})(1)$

Where $\mathrm{F}$ is the calculated flux (moles per unit area per unit time), $\mathrm{dC} / \mathrm{dt}$ (ppm $\mathrm{s}^{-1}$ ) is the slope of the linear regression of concentration vs. time, $\mathrm{V}$ is the chamber

volume $\left(\mathrm{m}^{3}\right), \mathrm{T}$ is the temperature $(\mathrm{K}), \mathrm{P}$ is pressure $(\mathrm{Pa})$ and $\mathrm{A}$ is the surface area $\left(\mathrm{m}^{2}\right)$ of the mesocosms or field plots that were measured. The Picarro measures gases on average every seven seconds but interpolated concentrations are reported for each gas approximately every two seconds. These raw interpolated data were used in the flux calculations. Fluxes calculated from Shimadzu GC-2014, Picarro and LGR concentration data will be referred to as Shimadzu GC-2014 fluxes, Picarro fluxes, and LGR fluxes, respectively throughout the manuscript.

\section{Monte Carlo simulations of instrument noise}

For the Picarro G2508 the noise of the instrument was first quantified by connecting it on a closed loop to a single bottle of compressed ambient air with approximately $0.33 \mathrm{ppm}$ of $\mathrm{N}_{2} \mathrm{O}, 400 \mathrm{ppm}$ of $\mathrm{CO}_{2}$, and 1,800 ppb of $\mathrm{CH}_{4}$ (Air Liquide America Specialty Gases). This single bottle was continuously measured for 30 hours. The Allan standard deviation of the resulting data set was modelled (Allan 1966) for each of the three gases with a combination of a Gaussian white noise term that follows a square root law, a flicker noise (also called 1/f or pink noise) term that leads to a 
constant Allan standard deviation independent of averaging, and a random walk noise term (also called brown noise). A Monte Carlo simulation of the instrument noise was performed, using optimized parameters for each of these three noise sources for each gas species. The simulation generated 200 realizations of a 30 hour time series and computed the Allan standard deviation of the resulting time series. This analysis was repeated for $\mathrm{N}_{2} \mathrm{O}$ only for the LGR analyzer with measured data provided by Los Gatos Research, Inc.

The average Allan standard deviation from the 200 Monte Carlo realizations is shown in Figure 1A as light colored symbols; the variability (1-sigma) of the simulated Allan standard deviation is also shown as error bars in the figure. Simple Gaussian (white) noise improves with the square root of the averaging period $\tau$, as indicated by the dashed gray lines in the figure. For $\mathrm{N}_{2} \mathrm{O}$ and $\mathrm{CO}_{2}$, the averaging follows the square root dependence for more than 1000 seconds; for $\mathrm{CH}_{4}$, the averaging improves out to about 200 seconds, after which, it becomes rather flat. The LGR analyzer exhibits a dramatically smaller (40X) white noise contribution, and a moderately smaller brown noise contribution $(2.6 \mathrm{X})$ than the Picarro analyzer.

\section{Mesocosm conditions for Objective 2}

Prior to gas flux measurements, both mesocosms were placed in a climate controlled chamber (Conviron® Model PGR15) for 11 weeks with the following conditions: $\mathrm{CO}_{2}: 700 \mathrm{ppm}$, day temperature: $33^{\circ} \mathrm{C}$, and night temperature: $23^{\circ} \mathrm{C}$. The

chambers simulated 15 hours of day $\left(875 \mu \mathrm{mol} \mathrm{m} \mathrm{m}^{-2} \mathrm{~s}^{-1}\right.$ of fluorescent and incandescent 
lamps) and 9 hours of night (lamps off). The mesocosms were maintained in bins of $12-15$ psu seawater.

\section{Gas Chromatography Methods}

Gas samples were analyzed on a Shimadzu GC-2014 equipped with a flame ionization detector for $\mathrm{CH}_{4}$ and $\mathrm{CO}_{2}$ and an electron capture detector for $\mathrm{N}_{2} \mathrm{O}$. Helium was used as a carrier gas and p5 $\left(5 \% \mathrm{CH}_{4}\right.$, balance Argon) as a makeup gas with a flow rate of $2.5 \mathrm{~mL} / \mathrm{min}$. The column flow rate was $25 \mathrm{~mL} / \mathrm{min}$. Hydrogen and Air were used for flame gases. The Shimadzu GC-2014 contains four 1/8" packed, stainless steel columns: 1.0 m Hayesep N or T 80/100 mesh, 4.0 m Hayesep D 80/100 mesh, 1.5 m Hayesep N 80/100 mesh, 1.5 m Hayesep N 80/100 mesh, 0.7 m Shimalite Q 100/180 mesh. The temperature of the columns was $80^{\circ} \mathrm{C}$. The temperature of the FID and ECD were $250^{\circ} \mathrm{C}$ and $325^{\circ} \mathrm{C}$ respectively.

\section{Impacts of closure time and averaging period with Picarro and LGR data}

For the Picarro, there is an improvement in the minimum detectable slope for each gas with increased chamber closure time, improving as $1 / \mathrm{T}^{1.5}(\mathrm{~T}=$ seconds $)$. Some of this improvement was due to the increased data contained in the measurement period (leading to an improvement with $1 / \mathrm{T}^{0.5}$ ), and the remainder was due to the larger time span of the fit, improving the determination of the slope (leading to a $1 / \mathrm{T}$ improvement). For the LGR the minimum detectable slope improves with increased chamber closure time, as $1 / \mathrm{T}^{0.75}$. This is due to an increasing influence of the brown noise component for times greater than 100 seconds for the analyzer. The minimum 
detectable slope for $\mathrm{N}_{2} \mathrm{O}$ for the LGR analyzer is one to two orders of magnitude lower than for the Picarro (Table 1). The LGR also had a higher precision for $\mathrm{N}_{2} \mathrm{O}$ because the lines used by mid-IR (LGR) are about $10^{5}$ times stronger than the lines used in near-IR (Picarro). However, the Allan variance for the Picarro extends to an hour for $\mathrm{N}_{2} \mathrm{O}$ (rather than 100 seconds for the LGR) (Figure 1) and is evidence of the reduced sensitivity of the Picarro to environmental factors. 
Table 1. Methane and carbon dioxide fluxes calculated from Picarro and Shimadzu GC-2014 data from mesocosm A-1 and A-2. Fluxes with p-value $>0.05$ and/or with slopes below the detection limit are reported as "not determined" (ND) in the table.

Normalized root mean square error (NRMSE) is also shown.

A. $\mathrm{CH}_{4}$

\begin{tabular}{|c|c|c|c|c|c|c|c|c|c|c|c|}
\hline \multirow[b]{2}{*}{ Mesocosm } & \multirow{2}{*}{$\begin{array}{l}\text { Meas. } \\
\#\end{array}$} & \multicolumn{5}{|c|}{ Picarro } & \multicolumn{5}{|l|}{ GC } \\
\hline & & $\begin{array}{l}\text { p- } \\
\text { value }\end{array}$ & NRMSE & $\mathrm{R}^{2}$ & $\begin{array}{l}\text { Slope } \\
(\mathrm{ppb} / \mathrm{s})\end{array}$ & $\begin{array}{l}\text { Flux } \\
\left(\mu \mathrm{mol} \mathrm{m} \mathrm{m}^{-2} \mathrm{~h}^{-1}\right)\end{array}$ & $\begin{array}{l}\text { Flux } \\
\left(\mu \mathrm{mol} \mathrm{m} \mathrm{m}^{-2} \mathrm{~h}^{-1}\right)\end{array}$ & $\begin{array}{l}\text { Slope } \\
(\mathrm{ppb} / \mathrm{s})\end{array}$ & $\mathrm{R}^{2}$ & NRMSE & p-value \\
\hline \multirow{3}{*}{ A-1 } & 1 & $<0.05$ & 0.18 & 0.63 & $4.98 \times 10^{-3}$ & 1.0 & ND & 0.06 & 0.00 & 0.18 & 0.93 \\
\hline & 2 & 0.58 & 0.31 & -0.04 & $9.28 \times 10^{-4}$ & ND & ND & 0.08 & 0.01 & 1.60 & 0.85 \\
\hline & 3 & $<0.05$ & 0.20 & 0.38 & $3.64 \times 10^{-3}$ & ND & ND & 0.14 & 0.01 & 1.54 & 0.79 \\
\hline \multirow{3}{*}{ A-2 } & 1 & $<0.05$ & 0.04 & 0.98 & 22.28 & 4604 & 4414 & 21.47 & 0.93 & 0.50 & $<0.05$ \\
\hline & 2 & $<0.05$ & 0.01 & 1.00 & 6.63 & 1371 & ND & 4.58 & 0.81 & 0.93 & $<0.05$ \\
\hline & 3 & $<0.05$ & 0.01 & 1.00 & 4.91 & 1016 & ND & 4.21 & 0.75 & 0.38 & $<0.05$ \\
\hline
\end{tabular}

B. $\mathrm{CO}_{2}$

\begin{tabular}{|c|c|c|c|c|c|c|c|c|c|c|c|}
\hline \multirow[b]{2}{*}{ Mesocosm } & \multirow{2}{*}{$\begin{array}{l}\text { Meas. } \\
\#\end{array}$} & \multicolumn{5}{|l|}{ Picarro } & \multicolumn{5}{|l|}{ GC } \\
\hline & & $\begin{array}{l}\mathrm{p}- \\
\text { value }\end{array}$ & NRMSE & $\mathrm{R}^{2}$ & $\begin{array}{l}\text { Slope } \\
(\mathrm{ppb} / \mathrm{s})\end{array}$ & $\begin{array}{l}\text { Flux } \\
\left(\mu \mathrm{mol} \mathrm{m} \mathrm{s}^{-2} \mathrm{~s}^{-1}\right)\end{array}$ & $\begin{array}{l}\text { Flux } \\
\left(\mu \mathrm{mol} \mathrm{m} \mathrm{s}^{-2} \mathrm{~s}^{-1}\right)\end{array}$ & $\begin{array}{l}\text { Slope } \\
(\mathrm{ppb} / \mathrm{s})\end{array}$ & $\mathrm{R}^{2}$ & NRMSE & p-value \\
\hline \multirow{3}{*}{ A-1 } & 1 & $<0.05$ & 0.03 & 0.99 & 31.90 & 1.8 & ND & 75.64 & 0.00 & 0.17 & 0.89 \\
\hline & 2 & $<0.05$ & 0.03 & 0.99 & 26.44 & ND & ND & 141.37 & 0.11 & 0.31 & 0.46 \\
\hline & 3 & $<0.05$ & 0.03 & 0.99 & 23.50 & ND & ND & 214.29 & 0.20 & 0.47 & 0.30 \\
\hline \multirow{3}{*}{ A-2 } & 1 & $<0.05$ & 0.02 & 1.00 & 550.02 & 31.6 & ND & 639.03 & 0.53 & 2.38 & 0.05 \\
\hline & 2 & $<0.05$ & 0.01 & 1.00 & 339.33 & 19.5 & ND & -149.71 & 0.10 & 0.44 & 0.52 \\
\hline & 3 & $<0.05$ & 0.01 & 1.00 & 284.95 & 16.4 & ND & 261.69 & 0.22 & 0.69 & 0.28 \\
\hline
\end{tabular}




\section{$\underline{\text { Acknowledgments }}$}

This study was funded by the USDA National Institute of Food and Agriculture (Hatch project \# 229286, grant to Moseman-Valtierra) and a Woods Hole Sea Grant award to Moseman-Valtierra and Tang. We thank Caleb Martin, PhD. for providing the $\mathrm{R}$ scripts used for data analysis. We also thank Isabella China and Melanie Garate for assistance with field work. 


\section{$\underline{\text { References }}$}

Allan, D. W. 1966. Statistics of atomic frequency standards. Proc. IEEE 54: 221-230.

Allen, D., R. Dalal, H. Rennenberg, R. L. Meyer, S. Reeves, and S. Schmidt. 2007. Spatial and temporal variation of nitrous oxide and methane flux between subtropical mangrove sediments and the atmosphere. Soil Biol. Biochem. 39: 622-631. doi:10.1016/j.soilbio.2006.09.013

Bange, H. 2006. New Directions: The importance of oceanic nitrous oxide emissions. Atmos. Environ. 40: 198-199. doi:10.1016/j.atmosenv.2005.09.030

Bartlett, K., D. Bartlett, R. Harriss, and D. Sebacher. 1987. Methane emissions along a salt marsh salinity gradient. Biogeochemistry 4: 183-202. doi:10.1007/BF02187365

Bartlett, K., R. Harriss, and D. Sebacher. 1985. Methane flux from coastal salt marshes. J. Geophys. Res. 90: 5710-5720.

Chmura, G. L., S. C. Anisfeld, D. R. Cahoon, and J. C. Lynch. 2003. Global carbon sequestration in tidal, saline wetland soils. Global Biogeochem. Cycles 17: 1111.

Christiansen, J., J. Korhonen, R. Juszczak, M. Giebels, and M. Pihlatie. 2011. Assesing the effects of chamber placement, manual sampling, and headspace mixing on CH4 fluxes in a laboratory experiment. Plant Soil 343: 171-185.

Christiansen, J. R., J. Outhwaite, and S. M. Smukler. 2015. Comparison of CO2, CH4 and $\mathrm{N} 2 \mathrm{O}$ soil-atmosphere exchange measured in static chambers with cavity ring-down spectroscopy and gas chromatography. Agric. For. Meteorol. 211212: 48-57. doi:10.1016/j.agrformet.2015.06.004 
Crosson, E. R. 2008. A cavity ring-down analyzer for measuring atmospheric levels of methane, carbon dioxide, and water vapor. Appl. Phys. B: Lasers Opt. 92: 403408.

Davidson, E. A., K. Savage, L. V. Verchot, and R. Navarro. 2002. Minimizing artifacts and biases in chamber-based measurements of soil respiration. Agric. For. Meteorol. 113: 21-37. doi:10.1016/S0168-1923(02)00100-4

Fleck, D., Y. He, C. Alexander, G. Jacobson, and K. Cunningham. 2013. Simultaneous soil flux measurements of five gases - $\mathrm{N} 2 \mathrm{O}, \mathrm{CH} 4, \mathrm{CO} 2, \mathrm{NH} 3$, and $\mathrm{H} 2 \mathrm{O}$ - with the Picarro G2508. Picarro Appl. Note AN034.

Forster, P., V. Ramaswamy, P. Artaxo, T. Berntsen, R. Betts, D. Fahey, J. Haywood, J. Lean, D. Lowe, G. Myhre, J. Nganga, R. Prinn, G. Raga, M. Schulz, and R. Van Dorland. 2007. Changes in Atmospheric Constituents and in Radiative Forcing., In S. Solomon, D. Qin, M. Mannin, Z. Chen, M. Marquis, K.B. Averyt, M. Tignor, and H.L. Miller [eds.], Climate Change 2007: The Physical Science Basis. Contribution of Working Group I to the Fourth Assessment Report of the Intergovernmental Panel on Climate Change. Cambridge University Press.

Gelfand, I., M. Cui, J. Tang, and G. P. Robertson. 2015. Short-term drought response of $\mathrm{N} 2 \mathrm{O}$ and $\mathrm{CO} 2$ emissions from mesic agricultural soils in the US Midwest. Agric. Ecosyst. Environ. 212: 127-133. doi:10.1016/j.agee.2015.07.005

Hensen, A., U. Skiba, and D. Famulari. 2013. Low cost and state of the art methods to measure nitrous oxide emissions. Environ. Res. Lett. 8: 025022. doi:10.1088/1748-9326/8/2/025022 
Hirota, M., Y. Senga, Y. Seike, S. Nohara, and H. Kunii. 2007. Fluxes of carbon dioxide, methane and nitrous oxide in two contrastive fringing zones of coastal lagoon, Lake Nakaumi, Japan. Chemosphere 68: 597-603. doi:10.1016/j.chemosphere.2007.01.002

LeTreut, H., R. Somerville, U. Cubasch, Y. Ding, C. Mauritzen, A. Mokssit, T. Peterson, and M. Prather. 2007. 2007: Historical overview of climate change. In S. Solomon, D. Qin, M. Manning, Z. Chen, M. Marquis, K.B. Averyt, M. Tignor and H.L. Miller [eds.], Climate Change 2007: The physical science basis. Contribution of working group 1 to the fourth assessment report of the intergovernmental panel on climate change. Cambridge University Press.

Liikanen, A., H. Silvennoinen, A. Karvo, P. Rantakokko, and P. Martikainen. 2009. Methane and nitrous oxide fluxes in two coastal wetlands in the northeastern Gulf of Bothnia, Baltic Sea. Boreal Environ. Res. 14: 351-368.

Liu, L., and T. L. Greaver. 2009. A review of nitrogen enrichment effects on three biogenic GHGs: the $\mathrm{CO} 2$ sink may be largely offset by stimulated $\mathrm{N} 2 \mathrm{O}$ and $\mathrm{CH} 4$ emission. Ecol. Lett. 12: 1103-1117. doi:10.1111/j.1461-0248.2009.01351.x

Martin, R. M., and S. Moseman-Valtierra. 2015. Greenhouse Gas Fluxes Vary Between Phragmites Australis and Native Vegetation Zones in Coastal Wetlands Along a Salinity Gradient. Wetlands. doi:10.1007/s13157-015-0690-y

MATLAB (2012), The MathWorks, Inc., Natick, Massachusetts, United States.

McClelland, J. W., and I. Valiela. 1998. Linking nitrogen in estuarine producers to landderived sources. Limnol. Oceanogr. 43: 577-585. 
Mcleod, E., G. L. Chmura, S. Bouillon, and others. 2011. A blueprint for blue carbon: toward an improved understanding of the role of vegetated coastal habitats in sequestering $\mathrm{CO}_{2}$. Front. Ecol. Environ. 9: 552-560.

Mitsch, W. J., and J. G. Gosselink. 2000. The value of wetlands: importance of scale and landscape setting. Ecol. Econ. 35: 25-33.

Mortazavi, B., B. J. Wilson, F. Dong, M. Gupta, and D. Baer. 2013. Validation and application of cavity-enhanced, near-infrared tunable diode laser absorption spectrometry for measurements of methane carbon isotopes at ambient concentrations. Environ. Sci. Technol. 47: 11676-11684.

Moseman-Valtierra, S., R. Gonzalez, K. Kroeger, and others. 2011. Short-term nitrogen additions can shift a coastal wetland from a sink to a source of N2O. Atmos. Environ. 45: 4390-4397. doi:10.1016/j.atmosenv.2011.05.046

Parkin, T. B., R. T. Venterea, and S. K. Hargreaves. 2012. Calculating the detection limits of chamber-based soil greenhouse gas flux measurements. J. Environ. Qual. 41: 705.

Poffenbarger, H. J., B. A. Needelman, and J. P. Megonigal. 2011. Salinity influence on methane emissions from tidal marshes. Wetlands 31: 831-842.

Rapson, T. D., and H. Dacres. 2014. Analytical techniques for measuring nitrous oxide. TrAC, Trends Anal. Chem. 54: 65-74.

R Core Team (2013). R A language and environment for statistical computing. Foundation for Statistical Computing. Vienna, Austria. URL http://ww.Rproject.org/ 
Robinson, A., D. Nedwell, R. Harrison, and B. Ogilvie. 1998. Hypernutrified estuaries as sources of $\mathrm{N} 2 \mathrm{O}$ emission to the atmosphere: the estuary of the River Colne, Essex, Uk. Mar. Ecol.: Prog. Ser. 164: 59-71.

Solomon, S., D. Qin, M. Manning, R. B. Alley, T. Berntsen, N. L. Bindoff, Z. Chen, A. Chidthaisong, J. M. Gregory, and G. C. Hegerl. 2007. Technical summary. In S. Solomon, D. Quin, M. Manning, Z. Chen, M. Marquis, K.B. Averyt, M. Tignor and H.L. Miller [eds.], Climate Change 2007: The physical science basis. Contribution of working group 1 to the fourth assessment report of the intergovernmental panel on climate change. Cambridge University Press.

Tong, C., W.-Q. Wang, C.-S. Zeng, and R. Marrs. 2010. Methane $\left(\mathrm{CH}_{4}\right)$ emission from a tidal marsh in the Min River estuary, southeast China. J. Environ. Sci. Health, Part A Toxic/Hazard. Subst. Environ. Eng. 45: 506-516. 


\section{CHAPTER 2}

\section{$\mathrm{N}_{2} \mathrm{O}, \mathrm{CO}_{2}$, AND $\mathrm{CH}_{4}$ FLUXES FROM THE LARGEST IFAS BIOLOGICAL NITROGEN REMOVAL WASTEWATER TREATEMENT SYSTEM IN THE U.S.}

Submitted to Water Research, February 2017

Authors: Elizabeth Q. Brannon*a, James C. McCaughey ${ }^{\mathrm{b}}$, Serena M. MosemanValtierra $^{\mathrm{a}}$, Barry E. Wenskowicz ${ }^{\mathrm{b}}$

${ }^{\text {a} D e p a r t m e n t ~ o f ~ B i o l o g i c a l ~ S c i e n c e s, ~ U n i v e r s i t y ~ o f ~ R h o d e ~ I s l a n d, ~ K i n g s t o n, ~ R I ~ 02881, ~}$ USA

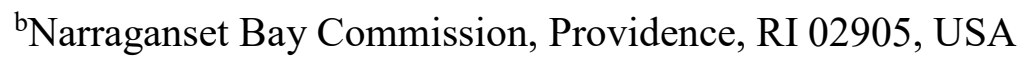

*Corresponding author phone: (978) 400 - 1187; email: ebrannon@my.uri.edu

Keywords: Integrated Fixed Film Activated Sludge (IFAS); Greenhouse gases; Nitrification; Denitrification; Cavity Ring Down Spectroscopy 


\begin{abstract}
Biological nutrient removal (BNR) processes at wastewater treatment plants are recognized as potential sources of greenhouse gases (GHGs) including nitrous oxide $\left(\mathrm{N}_{2} \mathrm{O}\right)$, methane $\left(\mathrm{CH}_{4}\right)$, and carbon dioxide $\left(\mathrm{CO}_{2}\right)$. However, no studies have quantified fluxes of these GHGs from the integrated fixed film activated sludge
\end{abstract} (IFAS) BNR process that includes plastic media to enhance microbial growth. In this study $\mathrm{N}_{2} \mathrm{O}, \mathrm{CH}_{4}$, and $\mathrm{CO}_{2}$ fluxes were simultaneously measured from four zones (two anoxic and two aerated) of the largest IFAS BNR system in the U.S. bimonthly for one year. Wastewater samples were also analyzed for concentrations of dissolved gases $\left(\mathrm{N}_{2} \mathrm{O}, \mathrm{CH}_{4}\right.$, and $\left.\mathrm{CO}_{2}\right)$, ammonium, nitrate, and nitrite. The highest fluxes of all three GHGs were from the principle (first) aerated zone. In terms of $\mathrm{CO}_{2}$ equivalence, the majority of GHG fluxes were from $\mathrm{CO}_{2}$, followed by $\mathrm{N}_{2} \mathrm{O}$ and minimal from $\mathrm{CH}_{4}$. Nitrous oxide fluxes ranged from $-7.6 \times 10^{-4}$ to $2.6 \mu \mathrm{mol} \mathrm{N}_{2} \mathrm{O} \mathrm{m}^{-2} \mathrm{~s}^{-1}$ accounting for 0.01 to $0.34 \%$ of influent nitrogen released as $\mathrm{N}_{2} \mathrm{O}$. Methane fluxes ranged from 0.01 to $10.8 \mu \mathrm{mol} \mathrm{CH}_{4} \mathrm{~m}^{-2} \mathrm{~s}^{-1}$ and represented 0.02 to $0.13 \%$ of influent chemical oxygen demand (COD) ( $\mathrm{kg} \mathrm{CH}_{4} / \mathrm{kg}$ influent COD). Carbon dioxide fluxes ranged from 2 to $2493 \mu \mathrm{mol} \mathrm{CO} 2 \mathrm{~m}^{-2} \mathrm{~s}^{-1}$ representing $0.2-1.1 \mathrm{~kg} \mathrm{CO}_{2} / \mathrm{kg}$ influent COD. Carbon dioxide fluxes were significantly related to $\mathrm{N}_{2} \mathrm{O}$ fluxes in the first anoxic zone and to $\mathrm{CH}_{4}$ fluxes in both aerated zones. Nitrous oxide fluxes had a strong inverse relationship with ammonium and a weak positive relationship with nitrate. The emissions of all three gases from the BNR system represent $12 \%$ of the total GHG emissions that the WWTP estimates are associated with the facility. Future studies are needed to further discern the mechanisms responsible for the GHG fluxes. 


\section{Introduction}

Wastewater treatment plants (WWTPs) have the potential to be significant sources of greenhouse gas (GHG) emissions on a national scale (US EPA, 2013). Although the U.S. Environmental Protection Agency estimated in 2011 that anthropogenic $\mathrm{N}_{2} \mathrm{O}$ and $\mathrm{CH}_{4}$ emissions from WWTPs accounted for $1.5 \%$ and $2.8 \%$ respectively of U.S. GHG emissions, these may be underestimates due to the large temporal and spatial variability reported in recent studies of GHG emissions from a range of wastewater treatment processes (Bao et al., 2015; Czepiel et al., 1993; Ren et al., 2015; Tomaszek and Czarnota, 2015; US EPA, 2013; Yan et al., 2014).

One major advance in wastewater treatment that may affect GHG emissions is the use of biological nutrient removal (BNR) to remove nitrogen (N) (Zhu et al., 2008). This type of BNR is the practice of removing reactive $\mathrm{N}$ from wastewater using naturally occurring nitrifying and denitrifying bacteria under aerated, anoxic, and anaerobic conditions. Removing the $\mathrm{N}$ helps avoid conditions that can lead to eutrophication in receiving waterbodies (Howarth et al., 2000; Zhu et al., 2008). Biological nutrient removal has recently been recognized as a potentially large source of $\mathrm{N}_{2} \mathrm{O}$ emissions from WWTPs because of the high concentrations of dissolved inorganic $\mathrm{N}$ undergoing rapid transformations and abundant microbial communities in wastewater (Grote, 2010; Tomaszek and Czarnota, 2015). During the BNR processes, two major sources by which $\mathrm{N}_{2} \mathrm{O}$ can be produced are microbial nitrification (predominantly in aerated zones) and denitrification (mainly in anoxic zones) (Tomaszek and Czarnota, 2015). A variety of organisms that produce $\mathrm{CO}_{2}$ through respiration or produce $\mathrm{CH}_{4}$ have been documented in BNR tanks (Bao et al., 2015; 
Gray et al., 2002; Lens et al., 1995). However, the relative magnitude of production and emission of these GHGs is not well studied and likely to depend on conditions and methods employed to facilitate $\mathrm{N}$ removal.

BNR technology has advanced quickly and there are now over two dozen different BNR system designs used worldwide (Grote, 2010). The two main categories of BNR are suspended growth (ex. activated sludge and aerated lagoons) and attached growth (ex. moving bed reactor and trickling filters) (Eddy et al., 2013). More recently, hybrid processes such as integrated fixed film activated sludge (IFAS) that combine both the suspended and attached growth designs have been developed (Eddy et al., 2013). Currently, there are 30 WWTPs utilizing the IFAS BNR method in the U.S (Carollo, 2012). Integrated fixed film activated sludge BNR systems utilize a plastic media designed to increase surface area for microbial growth without requiring additional tank volume and are commonly used to upgrade existing tanks to include BNR in order to meet new N discharge limits (Eddy et al., 2013).

Although several studies have measured $\mathrm{N}_{2} \mathrm{O}, \mathrm{CH}_{4}$, or $\mathrm{CO}_{2}$ emissions from various BNR technologies, the reported emissions vary by at least 2 orders of magnitude (Aboobakar et al., 2014; Bao et al., 2015; Tomaszek and Czarnota, 2015). Aerated zones of BNR systems thus far seem to have higher emissions than anoxic zones of all three GHGs due at least in part to the air stripping effect produced by the mechanical aeration (Ahn et al., 2010; Bao et al., 2015; Ren et al., 2015). Only two studies have examined seasonal variation in $\mathrm{N}_{2} \mathrm{O}$ emissions from $\mathrm{BNR}$ and report conflicting results (Sommer et al., 1998; Sümer et al., 1995). One study found that $\mathrm{N}_{2} \mathrm{O}$ emissions during the spring and summer were twice as high as those during the 
winter (Sommer et al., 1998) while the other did not find any seasonal variation (Sümer et al., 1995). For $\mathrm{CH}_{4}$ and $\mathrm{CO}_{2}$, some studies report a correlation between gas fluxes and wastewater temperature (Czepiel et al., 1993; Yan et al., 2014) but others do not (Wang et al., 2011; Yan et al., 2014).

Only four studies have examined all three GHGs simultaneously from BNR systems in the field and laboratory, none of which were IFAS. These studies found that $\mathrm{CO}_{2}$ and $\mathrm{N}_{2} \mathrm{O}$ fluxes were larger than $\mathrm{CH}_{4}$ fluxes and that influent $\mathrm{C} / \mathrm{N}$ ratio may impact the magnitude of all three GHG fluxes (Bao et al., 2016; Kong et al., 2016; Ren et al., 2015; Yan et al., 2014). Water consumption, $\mathrm{N}$ intake, and wastewater generation and processing rates are influenced by several environmental conditions, such as weather and climate, that vary over time and also are likely to vary between each individual WWTP; these factors therefore influence variation in GHG fluxes (Brotto et al., 2015). The implementation of new methods such as IFAS BNR may further increase the heterogeneity of GHG emissions within and between BNR systems.

This is the first known study to examine $\mathrm{N}_{2} \mathrm{O}, \mathrm{CH}_{4}$, and $\mathrm{CO}_{2}$ fluxes simultaneously from an IFAS BNR system in the U.S. Specifically, this study examines (1) temporal (bi-monthly across annual cycle) and spatial variability in GHG emissions from 4 major zones (Pre-Anoxic, Aerated IFAS, Post Anoxic, and ReAeration) of one IFAS BNR tank at the Field's Point WWTP in Providence, RI and (2) potential relationships between GHG fluxes and a suite of water and tank parameters to understand potential environmental controls of GHG fluxes. In addition we use the gas fluxes and concentrations of dissolved gases to discern in which zones 
the emitted gases are produced. Finally, we use the simultaneous measurements of all three major GHGs to estimate the total GHG emissions (and relative importance of each gas) from the IFAS BNR system, and evaluate the potential importance of this major component to the overall GHG budget of the WWTP.

\section{Materials and Methods}

\subsection{Field Site}

This study was conducted at the Narragansett Bay Commission's Field's Point WWTP in Providence, RI. This municipal WWTP treats combined sewage and serves a population of approximately 226,000 . The facility has a pre-treatment program to prevent non-biogenic pollutants from entering the wastewater influent. The facility provides primary treatment (grit chambers and primary clarifiers) and chlorination/dechlorination disinfection for flows up to 77 MGD and an additional 123 MGD of treatment to wet weather flows for a total treatment capacity of 200 MGD. Secondary treatment (fine screening and activated sludge that includes BNR) is provided for flows up to 77 MGD.

The Field's Point facility uses the largest IFAS BNR process in the U.S. as part of its secondary treatment. Existing aeration tanks were upgraded to a total of 10 IFAS BNR tanks in 2013 in order to meet a seasonal $5.0 \mathrm{mg} / \mathrm{L}$ total $\mathrm{N}$ limit from May $1^{\text {st }}$ through October $31^{\text {st }}($ RI DEM, 2005). Each IFAS BNR tank consists of four zones: Pre-anoxic, Aerated IFAS, Post-Anoxic, and Re-Aeration (Figure 1). Each of the 10 IFAS BNR tanks contains identical zones, dimensions, and retention times. The Aerated IFAS zone contains molded high-density polyethylene disc media (25 
$\mathrm{mm}$ diameter; $10 \mathrm{~mm}$ length) at a fill rate of approximately $50 \%$, providing an effective surface area of $500 \mathrm{~m}^{2} / \mathrm{m}^{3}$ for biofilm to grow.

\subsection{Sampling Campaign}

In order to examine temporal and spatial variability of GHG emissions across an annual cycle (Objective 1), GHG fluxes were measured approximately twice a month for one year (June 2014 - June 2015) in one of the IFAS BNR tanks (Figure 1). All measurements were collected between the hours of 8:00 am and 1:00 pm during weekdays. Three gas flux measurements were distributed approximately equally across each zone, except for the Aerated IFAS zone where all three measurements were collected in relatively the same location due to logistical constraints (Figure 1). There was approximately 3 - 30 minutes (on one occasion up to one hour) between each measurement within a zone.

In order to examine potential relationships between GHG fluxes and several water and tank parameters (Objective 2), water samples were collected within 3 hours (either before or after) of the GHG flux measurements and immediately stored on ice. Water samples were collected from the same locations as the GHG flux measurements, except for the Aerated IFAS zone where the size of the zone prevented this (Figure 1). Water samples were analyzed for dissolved gas concentration and multiple other water and tank conditions (see sections 2.4 and 2.5).

Due to logistical constraints, gas measurements and water samples were not collected during August and September and water samples were not collected on one day in October (10/28/14). Gas fluxes and water samples were collected only on 
single dates (rather than bimonthly) in December, January, February, and April. In January, February, March, and April only two measurements/samples (rather than 3) were collected from each zone.

\subsection{Greenhouse Gas Fluxes}

To quantify $\mathrm{N}_{2} \mathrm{O}, \mathrm{CH}_{4}$, and $\mathrm{CO}_{2}$ fluxes from the $\mathrm{BNR}$ tank, a real time $\mathrm{GHG}$ analyzer and pump (Picarro G2508, Santa Clara, CA) were connected to a transparent (polypropylene) floating chamber (height: $0.3 \mathrm{~m}$, width: $0.3 \mathrm{~m}$, length: $0.5 \mathrm{~m}$ ) via nylon tubing (inner diameter: $0.5 \mathrm{~cm}$, total length: $(61.0-91.4 \mathrm{~m})$. Pressure inside the chamber maintained equilibrium with atmospheric pressure via a coiled stainless steel tube (inner diameter of $0.71 \mathrm{~mm}$ ) attached to a port at the top of the chamber. The Picarro G2508 uses cavity ring down spectroscopy to measure $\mathrm{N}_{2} \mathrm{O}, \mathrm{CH}_{4}$, and $\mathrm{CO}_{2}$ simultaneously, real time, approximately every two seconds. Gas measurements were made for approximately 4-10 minutes at each location.

In the two non-aerated zones (Pre-Anoxic and Post Anoxic) and the ReAeration zone (air flow rates are designed to be minimal, about 100 standard cubic feet per minute $(\mathrm{scfm}))$, gas fluxes $\left(\mathrm{F}, \mu \mathrm{mol} \mathrm{m} \mathrm{m}^{-2} \mathrm{~s}^{-1}\right)$ were calculated following methods used by Mello et al., (2013) for non-aerated stages. The change in GHG concentration over time was determined using a linear regression. Approximately the first 2 to 3.5 minutes of data were not included in the flux calculations (4-10 minutes remaining) in order to account for gases passing through the length of the tubing between the analyzer and chamber. The statistical significance of each gas flux was determined as outlined in Brannon et al. (2016) using a combination of the p-value for 
the linear regression and analytical detection limits of the analyzer. Fluxes from the Pre-Anoxic, Post Anoxic, and Re-Aeration zones that were not significant (4\%, 6\%, and $3 \%$ of $\mathrm{N}_{2} \mathrm{O}, \mathrm{CH}_{4}$ and $\mathrm{CO}_{2}$ emissions respectively) were excluded from statistical analysis. In addition, one anomalous negative $\mathrm{N}_{2} \mathrm{O}$ flux from the Re-Aeration zone was excluded from statistical analysis.

Gas fluxes $\left(\mathrm{F}, \mu \mathrm{mol} \mathrm{m} \mathrm{m}^{-2} \mathrm{~s}^{-1}\right)$ from the Aerated IFAS zone were calculated based on a different method used by Mello et al. (2013) for aerated stages, using the flow rate of the off gas from the wastewater $\left(\mathrm{Q}, \mathrm{m}^{3} \mathrm{~s}^{-1}\right)$, the equilibrium concentration of

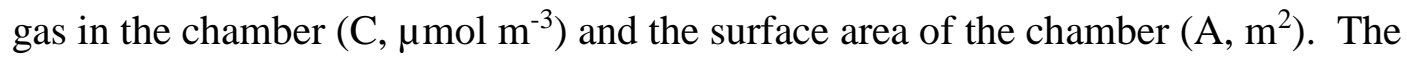
flow rate of the off gas $(\mathrm{Q})$ was estimated based on the known total air flow to both the Aerated IFAS and Re-Aeration zones, which was monitored by the WWTP operators, and the design parameter for the proportion of air flow to each zone. The equilibrium concentration was determined using a Gompertz 4P curve, a non-linear sigmoid that permits a non-zero lower asymptote, in JMP for each chamber deployment $(J M P, 1989)$. The Gompertz 4P curve was selected based on observations of best fit to the data relative to other potential nonlinear curves. If the equilibrium concentration was greater than the detection limit of the analyzer plus the minimum precision of the analyzer (Picarro Inc., 2015), then the flux was considered significant and was included in statistical analysis. All flux calculations were performed in JMP, R (R Core Team, 2013) and Excel. 


\subsection{Dissolved Greenhous Gases}

A $35 \mathrm{~mL}$ subsample of the water samples collected as outlined in Section 2.2 was transferred to a $60 \mathrm{~mL}$ syringe and equilibrated with helium within 4.5 hours of collection (Guisasola et al., 2009). The samples were analyzed on Shimadzu GC-2014 gas chromatograph within five days of collection or placed in pre-evacuated glass vials with rubber septa (Labco Limited) for long term storage (typically less than a month, but on three occasions up to 3 months). Three specialty gas standards (Airgas, Billerica MA; $\mathrm{N}_{2} \mathrm{O}: 0.5$ - 372 ppm; $\mathrm{CH}_{4}: 2.4-433$ ppm; $\mathrm{CO}_{2}: 302-20,510$ ppm) were used to calibrate the Shimadzu GC-2014 daily. Dissolved gas concentrations were calculated as outlined in Weiss and Price (1980) for $\mathrm{N}_{2} \mathrm{O}$, Lammers and Suess (1994) for $\mathrm{CH}_{4}$, and Weiss (1974) for $\mathrm{CO}_{2}$.

\subsection{Water and Tank Parameters}

In order to examine potential relationships between water and tank process parameters and GHG fluxes, a subsample (approximately $15 \mathrm{~mL}$ ) of the water sample collected as outlined in Section 2.2 was filtered $(45 \mu \mathrm{m})$ within 4 hours and frozen until analyzed for ammonium concentration using the phenolhypochlorite method (Solorzano et al. 1969) and nitrite using Hach Spectrophotometric Methods 102066. Another subsample was filtered, acidified, and analyzed for nitrate using Hach Spectrophotometric Methods 102066. Due to logistical constraints, water samples from 7/21/14 were not analyzed for ammonium, nitrite, and nitrate. In addition the following data was provided by the Narragansett Bay Commission: wastewater temperature (HACH Model 57900-00, Loveland, CO), influent flow rate, dissolved 
oxygen (DO) (HACH Model 57900-00, Loveland, CO) in the Aerated IFAS zone, internal mixed liquor return flow, return activated sludge flow, and sludge volume index (SVI).

\subsection{Statistics}

To examine differences in GHG fluxes between zones (Pre-Anoxic, Aerated IFAS, Post Anoxic, and Re-Aeration) and over seasons (summer 2014, fall, winter, and summer 2015) during the yearlong measurement period, a two-factor ANOVA (zone $\mathrm{x}$ season) was performed for each gas. The time of day of the measurement was not included as a factor in this analysis because differences in fluxes between dates were not significantly related to the time the measurements were collected (checked with linear regressions, data not shown). Assumptions of homoscedasticity and normality were checked using residual plots and data was log transformed when necessary. In all cases, a post hoc Tukey test was performed to determine which zones and seasons were significantly different. The same statistical approach was used for dissolved gas concentrations.

Potential inter-relationships between GHG fluxes were examined using linear regressions; one regression for each zone and gas combination was performed. To determine potential mechanisms of $\mathrm{N}_{2} \mathrm{O}$ fluxes, relationships between $\mathrm{N}_{2} \mathrm{O}$ fluxes and dissolved $\mathrm{N}$ species (ammonium, nitrate, and nitrite) were examined using a principal components analysis (PCA). The PCA included data from all four zones (comprised of 3 replicates per zone on each date over an annual cycle). Ammonium, nitrate, and nitrite data that were below the detection limit were censored using the ranks of the u- 
scores prior to being included in the PCA (Helsel, 2011). Separate regressions were completed to test relationships of each GHG flux with DO in the Aerated IFAS zone. A multiple regression was performed for each gas flux for each zone with the following predictors: water temperature, water flow rate, and SVI. Only significant regressions are reported. All statistical analyses were performed in R (R Core Team, 2013).

\section{Results}

\subsection{Characteristics and Performance of IFAS BNR System}

The characteristics and performance data of Tank 1 of the IFAS BNR system at Field's Point during this study are summarized in Table 1. There was about a $6^{\circ} \mathrm{C}$ difference in water temperature between the warmest and coldest day during the study. Air flow and DO in the Aerated IFAS zone were lowest in the fall. The average percent $\mathrm{N}$ removal was $74 \%$ and was lowest in the winter. There was a decrease in ammonium concentrations from the BNR system influent to the Pre-Anoxic zone. Nitrate and nitrite concentrations were generally low relative to ammonium. The highest nitrate concentrations (averaging $2.04 \pm 1.49$ ) were in the Aerated IFAS zone, while nitrite concentrations were often below the detection limit, but were also generally highest in the Aerated IFAS zone.

\subsection{Spatial and Temporal Variability of Greenhouse Gas Fluxes}

During the yearlong study, $\mathrm{N}_{2} \mathrm{O}$ fluxes ranged from $-7.6 \times 10^{-4}$ to $2.6 \mu \mathrm{mol} \mathrm{m} \mathrm{m}^{-2}$

$\mathrm{s}^{-1}$ (Figure 2A). For $\mathrm{N}_{2} \mathrm{O}$ fluxes, the zones, seasons, and the interaction between zones 
and seasons were significant (Table 2, Figure 2A). Nitrous oxide fluxes from the Aerated IFAS zone were highest, followed by those from the Re-Aeration zone (Table 2, Figure 2A). On average $\mathrm{N}_{2} \mathrm{O}$ fluxes from the Aerated IFAS and Re-Aeration zones represented $75 \%$ and $21 \%$ respectively of the total $\mathrm{N}_{2} \mathrm{O}$ fluxes from all four zones. Nitrous oxide fluxes from the two anoxic zones (Pre and Post Anoxic) were significantly different from each other and represented a small proportion of the $\mathrm{N}_{2} \mathrm{O}$ fluxes, on average a combined $4 \%$ of the total $\mathrm{N}_{2} \mathrm{O}$ fluxes from all four zones (Table 2, Figure 2A). Nitrous oxide fluxes in the summer of 2014 were significantly lower than those in the fall and winter (Table 2, Figure 2A). Exceptionally large $\mathrm{N}_{2} \mathrm{O}$ fluxes were measured on two dates, 7/21/2014 (summer 2014) when fluxes from the Aerated IFAS zone were approximately 3.5 times larger than the yearly average from that zone and 1/14/15 (winter), the only date when fluxes from the Re-Aeration zone were larger than those from the Aerated IFAS zone (Figure 2A). These dates illustrated the complex nature of the temporal variability and interaction between season and zone, as they were distinct from other dates within their respective seasons.

During the course of this study, $\mathrm{CH}_{4}$ fluxes ranged from 0.01 to $10.8 \mu \mathrm{mol} \mathrm{m}{ }^{-2}$ $\mathrm{s}^{-1}$ (Figure 2B). As with $\mathrm{N}_{2} \mathrm{O}$, there was a significant difference in $\mathrm{CH}_{4}$ fluxes between zones, seasons, and the interaction of zones and seasons (Table 2, Figure 2B). The Aerated IFAS zone had significantly higher $\mathrm{CH}_{4}$ fluxes than all other zones (Table 2, Figure 2B). On average $74 \%$ of the total $\mathrm{CH}_{4}$ fluxes from the BNR system were from the Aerated IFAS zone. Methane fluxes in the fall were significantly larger than those from other seasons (Table 2, Figure 2B). The significant interaction in $\mathrm{CH}_{4}$ fluxes between season and zone (Table 2, Figure 2B) is illustrated in the fall and one 
date in the winter (3/3/15) when $\mathrm{CH}_{4}$ fluxes from the Post Anoxic zone surpassed those from the Pre-Anoxic and Re-Aeration zones and even the Aerated IFAS zone on 3/3/15 (Figure 2B).

Carbon dioxide fluxes ranged over three orders of magnitude from 2 to 2493 $\mu \mathrm{mol} \mathrm{m} \mathrm{s}^{-2}$ (Figure 2C). Similar to both $\mathrm{N}_{2} \mathrm{O}$ and $\mathrm{CH}_{4}$, there were significant differences in $\mathrm{CO}_{2}$ fluxes between the four zones, with the largest fluxes from the Aerated IFAS zone (Table 2, Figure 2C). Similar to $\mathrm{N}_{2} \mathrm{O}$, the second largest $\mathrm{CO}_{2}$ fluxes were from the Re-Aeration zone with minimal fluxes from the two anoxic zones (Table 2, Figure 2C). There were also significant differences in $\mathrm{CO}_{2}$ fluxes between seasons and the interaction of zone and season (Table 2, Figure 2C). The lowest $\mathrm{CO}_{2}$ fluxes were in the winter (Table 2, Figure 2C).

In general, although the three GHGs exhibited different temporal trends, the highest fluxes of all three GHGs were from the Aerated IFAS zone (Figure 2 and Table 2). There was a significant positive linear relationship between $\mathrm{CH}_{4}$ and $\mathrm{CO}_{2}$ in the Aerated IFAS $\left(p<0.001, r^{2}=0.40\right.$, Figure $\left.3 A\right)$ and Re-Aeration zones $(p<0.001$, $r^{2}=0.22$, data not shown). There was also a significant positive linear relationship between $\mathrm{N}_{2} \mathrm{O}$ and $\mathrm{CO}_{2}$ fluxes in the Pre-Anoxic zone $\left(\mathrm{p}<0.001, \mathrm{r}^{2}=0.47\right.$, Figure $\left.3 \mathrm{~B}\right)$.

\subsection{Dissolved Greenhouse Gas Concentrations and Production}

In order to better understand whether GHG fluxes were produced in the same zone they were emitted from or if they were produced upstream, dissolved gas concentrations were measured across all four zones and the influent and effluent of the BNR system. The dissolved $\mathrm{N}_{2} \mathrm{O}, \mathrm{CO}_{2}$, and $\mathrm{CH}_{4}$ concentrations displayed distinct 
temporal and spatial patterns from the fluxes of the same GHGs (Figures 2 and 4).

Dissolved $\mathrm{N}_{2} \mathrm{O}$ concentrations were relatively low and ranged from 0.01 to $3.22 \mu \mathrm{M}$, except for one date $(1 / 14 / 15)$ when concentrations were the highest (up to $9.2 \mu \mathrm{M}$ ) in all zones except the Inflow (Figure 4A). Unlike $\mathrm{N}_{2} \mathrm{O}$ fluxes, there were not significant differences in dissolved $\mathrm{N}_{2} \mathrm{O}$ concentrations between zones or the interaction between zones and seasons (Table $\mathrm{S} 1$ ). However, dissolved $\mathrm{N}_{2} \mathrm{O}$ concentrations did significantly differ across seasons with the highest concentrations measured in winter, but this was partly driven by the single winter date (1/14/15) with exceptionally high values (Figure 4A, Table S1).

In general, dissolved $\mathrm{CH}_{4}$ concentrations decreased as the water flowed through the BNR treatment process except on a few dates $(6 / 30 / 14,7 / 21 / 14,11 / 20 / 14$, 5/7/15) when concentrations in the BNR tank were higher than in the influent (Figure 4B). Although dissolved $\mathrm{CH}_{4}$ concentrations exhibited significant differences between zones, seasons, and the interaction of zones and seasons, the patterns were distinct from those of $\mathrm{CH}_{4}$ fluxes (Figure 4B, Table $\mathrm{S} 1$ ). In contrast to $\mathrm{CH}_{4}$ fluxes, which were highest in the Aerated IFAS zone, dissolved $\mathrm{CH}_{4}$ concentrations were highest in the Pre-Anoxic zone (Figure 4B, Table S1). Further, unlike $\mathrm{CH}_{4}$ fluxes which were highest in the fall, dissolved $\mathrm{CH}_{4}$ concentrations in the summer of 2015 were higher than the other seasons (Figure 4B, Table S1).

Dissolved $\mathrm{CO}_{2}$ concentrations ranged from 14.4 to $1346.3 \mu \mathrm{M}$ (Figure 4C). There were significant differences in dissolved $\mathrm{CO}_{2}$ concentrations between zones and seasons, but not the interaction of zones and seasons (Table S1). However, different trends were observed in the dissolved $\mathrm{CO}_{2}$ concentrations than the $\mathrm{CO}_{2}$ fluxes. While 
$\mathrm{CO}_{2}$ fluxes were largest from the Aerated IFAS zone, dissolved $\mathrm{CO}_{2}$ concentrations were high in all zones except the Pre-Anoxic and Inflow (Table S1). Further, while $\mathrm{CO}_{2}$ fluxes were lowest in the winter, dissolved $\mathrm{CO}_{2}$ concentrations were significantly higher in the winter and summer 2014 than the fall and summer 2015 (Figure 4C and Table S1).

Given the strong mismatch between gas emissions and dissolved concentrations, we used both types of data along with flow rate in a set of mass balance equations to estimate the production of each gas in the water column for each zone. These production values were calculated as outlined in Yan et al. (2014) and assumed solids were inert (Diagram S1). In general, the Aerated IFAS zone had the highest production estimates of all three gases (Table S2). This was also the zone that had the highest emissions of all three gases (Table 2). One exception was the January date (1/14/15) when the highest $\mathrm{N}_{2} \mathrm{O}$ fluxes from the Re-Aeration zone were observed. On this date, high $\mathrm{N}_{2} \mathrm{O}$ production was estimated in the Aerated IFAS, Post-Anoxic and Re-Aeration zones.

\subsection{Relationships between Gas Fluxes and Water and Tank Parameters.}

A PCA was used to examine relationships between $\mathrm{N}_{2} \mathrm{O}$ fluxes and dissolved $\mathrm{N}$ concentrations across all zones and dates (Figure 5). The first component explained $48 \%$ of the variance and the second component explained an additional $24 \%$ of the variance for a total of $72 \%$ explained by the first two principal components (Figure 5). Nitrate loaded on the first axis while ammonium, nitrite, and $\mathrm{N}_{2} \mathrm{O}$ flux loaded equally

on both axis (Figure 5). The opposite orientation of $\mathrm{N}_{2} \mathrm{O}$ and ammonium suggests that 
$\mathrm{N}_{2} \mathrm{O}$ fluxes had a strong inverse relationship with ammonium concentrations (Figure 5). The small angle between $\mathrm{N}_{2} \mathrm{O}$ and nitrate suggests that $\mathrm{N}_{2} \mathrm{O}$ flux and nitrate had a moderate positive relationship (Figure 5). The nearly $90^{\circ}$ orientation between $\mathrm{N}_{2} \mathrm{O}$ and nitrite suggests that there was weak linkage between the two (Figure 5).

There was not a significant relationship between DO concentration and any of the gas fluxes from the Aerated IFAS zone (data not shown). In the Post Anoxic zone there was a significant relationship between water temperature and $\mathrm{CO}_{2}$ fluxes $(\mathrm{p}=$ 0.04). There was a significant relationship between temperature and $\mathrm{CH}_{4}$ flux in the Aerated IFAS zone $(\mathrm{p}=0.04)$.

\section{Discussion}

The new IFAS BNR system at Field's Point successfully removed total N during the course of this study (Table 1A). The lower percentage of $\mathrm{N}$ removal observed in the winter was likely because the $\mathrm{N}$ discharge limit is only in effect from May through October. At the end of the discharge limit season the air flow rate is often decreased by plant operators to lower expenses, which explains the low DO in the Aerated IFAS zone in the fall (Table 1). The decrease in microbial activity during colder months is also another key factor in the lower $\mathrm{N}$ removal in observed in the winter. The decrease in ammonium concentrations between the BNR system influent and the Pre-Anoxic zone was unexpected because the low DO concentration in this zone should limit nitrification (conversion of ammonium to nitrate) (Table 1). This decrease in ammonium is due to the fact that the Pre-Anoxic zone also receives internal mixed liquor recycle water from the Aerated IFAS zone. This water will be 
low in ammonium, therefore diluting the ammonium concentration in the Pre-Anoxic zone. Higher nitrate and nitrite concentrations in the Aerated IFAS zone were expected because the DO concentration in this zone is designed to favor nitrification (Table 1).

\subsection{Overview of GHG Emissions}

This study found measurable fluxes of all three GHGs from both aerated and anoxic zones of the IFAS BNR system. Comparisons to other studies indicate that direct GHG fluxes from IFAS BNR may be lower than from other methods of BNR. Nitrous oxide fluxes in this study accounted for 0.01 to $0.34 \%$ of influent $N$. This falls at the lower end of the range $(0.001-8.2 \%)$ reported by previous studies on $\mathrm{N}_{2} \mathrm{O}$ emissions from various types of BNR processes (Tomaszek and Czarnota, 2015). The percent of influent chemical oxygen demand (COD) released as $\mathrm{CH}_{4}$ ranged from 0.02 to $0.13 \% \mathrm{~kg} \mathrm{CH}_{4} / \mathrm{kg}$ influent COD. This was also at the low end of the range of reported $\mathrm{CH}_{4}$ emissions $(0.07-1.13 \%)$ from other BNR processes (Aboobakar et al., 2014). Carbon dioxide fluxes represented $0.2-1.1 \mathrm{~kg} \mathrm{CO}_{2} / \mathrm{kg}$ influent $\mathrm{COD}$, which is similar to the reported range from other BNR systems of $0.58-0.97 \mathrm{~kg} \mathrm{CO}_{2} / \mathrm{kg} \mathrm{COD}$ (Bao et al., 2015).

\subsection{Aerated IFAS zone as a hotspot for GHG emissions}

Despite low overall emissions, the Aerated IFAS zone of the BNR system emitted the largest fluxes of all three GHGs compared to other zones, 75\%, 74\%, 82\% of total $\mathrm{N}_{2} \mathrm{O}, \mathrm{CH}_{4}$, and $\mathrm{CO}_{2}$ fluxes from the BNR tank respectively. Higher $\mathrm{N}_{2} \mathrm{O}, \mathrm{CH}_{4}$, 
and $\mathrm{CO}_{2}$ fluxes from aerated zones vs. anoxic zones was expected as it has been reported by previous studies conducted in other BNR processes (Ahn et al., 2010; Bao et al., 2015; Law et al., 2012; Mello et al., 2013; Ren et al., 2015; Wang et al., 2011). In aerated zones, mechanical air stripping is thought to be the main process contributing to GHG emissions (Mello et al., 2013). However, oxygenated conditions may also lead to greater production rates of GHGs. For example, increased $\mathrm{N}_{2} \mathrm{O}$ fluxes from aerated zones may be due to increased nitrification, incomplete denitrification, or altered environmental properties, such as temperature, that indirectly affect $\mathrm{N}_{2} \mathrm{O}$ production and consumption (Aboobakar et al., 2013).

Our study did not definitively discern whether these GHGs were produced in the aerated zone or previous zones, however, our estimates of production rates for this study suggested that there was high production of all three GHGs in the Aerated IFAS zone (Table S2). Although these production estimates assume solids are inert and dissolved concentrations in the effluent of BNR are similar to those in the final clarifiers, they should provide a good indication of general trends in production in consumption. While $\mathrm{N}_{2} \mathrm{O}$ and $\mathrm{CO}_{2}$ production in the Aerated IFAS zone is expected, $\mathrm{CH}_{4}$ production in aerobic zones such as the Aerated IFAS zone may not typically be expected as methanogenesis occurs under strict anaerobic conditions (Aboobakar et al., 2014). In this study, it is likely that anaerobic micro-sites occurred in biofilms on the inner portions of the floc and/or plastic media present in the Aerated IFAS zone leading to the high $\mathrm{CH}_{4}$ production in this zone. Other studies have documented strictly anaerobic bacteria and archaea (including methane producers) in oxic BNR reactors (Lens et al., 1995). 


\subsection{Temporal variability of GHG emissions}

All three GHGs demonstrated temporal variability that was not a simple function of seasonality. $\mathrm{N}_{2} \mathrm{O}$ fluxes exhibited the largest range within a single zone (4 orders of magnitude) over the course of the year. Temporal differences in $\mathrm{N}_{2} \mathrm{O}$ fluxes were largely driven by two dates, one date in July when fluxes from the Aerated IFAS zone were large and one date in January when fluxes from the Re-Aeration zone were large (Figure 2A). Unfortunately, water samples were not collected on the July date making it difficult to determine the cause of the increased fluxes. The January measurement was the date with the highest dissolved $\mathrm{N}_{2} \mathrm{O}$ concentrations overall and a consistent increase was observed in these values from the inflow to the re-aeration zone on this single date (Figure 2A and $3 \mathrm{~A}$ ). It is possible that the colder wastewater temperatures in January (Table 1) increased the solubility of $\mathrm{N}_{2} \mathrm{O}$, such that it was not completely stripped in the first aeration zone (Aerated IFAS) but rather remained dissolved until the second aeration zone (Re-Aeration zone). This day had the highest $\mathrm{N}_{2} \mathrm{O}$ production in the Aerated IFAS, Post Anoxic, and Re-Aeration zones (data not shown). This was also the date with the highest inflow nitrate concentration, which suggests that denitrification may have been a source of $\mathrm{N}_{2} \mathrm{O}$ production.

For $\mathrm{CH}_{4}$ fluxes, the apparent seasonal difference was dominated by increased fluxes from the Post Anoxic zone in the fall (Figure 2B). Dissolved $\mathrm{CH}_{4}$ concentrations in the fall showed a unique pattern of increase from the Aerated IFAS to Post Anoxic zones (Figure 4B). This was complimented by an increase in $\mathrm{CH}_{4}$ production in the Post Anoxic zone in the fall. This increase in $\mathrm{CH}_{4}$ production and emission may be related to a thick floating sludge that developed on the Post Anoxic 
zone in the fall potentially limiting the concentration of DO in the surface water of the zone. In addition, lower DO concentrations in the Aerated IFAS zone (immediately before the Post Anoxic) in the fall (relative to other seasons) may have resulted in influent to the Post Anoxic zone with lower DO concentrations. Both of these explanations could contribute to lower DO concentrations in the Post Anoxic zone and result in an improved environment for $\mathrm{CH}_{4}$ production.

Out of the three gases, $\mathrm{CO}_{2}$ exhibited the lowest temporal variability (Figure 2C). The lower $\mathrm{CO}_{2}$ fluxes in winter may have been a result of reduced microbial activity, although there was not a consistent significant relationship between water temperature and $\mathrm{CO}_{2}$ emissions. Another study of the $\mathrm{N}$ removal tanks at a nearby WWTP in New Hampshire also found that $\mathrm{CO}_{2}$ did not have a significant correlation with temperature (Czepiel et al., 1993). Lower air flow rates in the IFAS zone in the winter may be another explanation for the lower $\mathrm{CO}_{2}$ fluxes in the winter. $\mathrm{CO}_{2}$ production in the winter was not lower than other seasons. It is possible that the $\mathrm{CO}_{2}$ was still produced in the winter but remained in the dissolved form, supported by the higher dissolved $\mathrm{CO}_{2}$ concentrations and lower fluxes observed in the winter.

\subsection{Relationships between GHG Fluxes and Water and Tank Parameters}

The PCA indicated that $\mathrm{N}_{2} \mathrm{O}$ fluxes were related to both ammonium and nitrate. Since data from all zones were included in the PCA, it is possible that denitrification is an important contributing factor in anoxic zones whereas nitrification is important in aerated zones. 
The lack of significant consistent relationships between any of the GHGs and DO, water temperature, SVI, and water flow rate was surprising. However, GHGs are known to result from complicated combinations of many biological and mechanical processes. The inter-relationship of the gases to each other, in contrast, suggest there may be another unmonitored environmental variable that affects them all. For example, the positive relationship between $\mathrm{CO}_{2}$ and $\mathrm{CH}_{4}$ fluxes in the Aerated IFAS zone suggests that these gases may have similar release mechanisms in this zone, likely striping due to mechanical aeration. More extensive data sets and alternative modeling techniques may improve the ability to predict which critical environmental factors govern GHG emissions from WWTPs.

\subsection{Overall Greenhouse Gas Emissions}

Simultaneously examination of the fluxes of all three GHGs $\left(\mathrm{N}_{2} \mathrm{O}, \mathrm{CH}_{4}\right.$, and $\mathrm{CO}_{2}$ ) enables us to evaluate the emissions in terms of $\mathrm{CO}_{2}$ equivalence (using global warming potentials of 265 for $\mathrm{N}_{2} \mathrm{O}$ and 28 for $\mathrm{CH}_{4}$ ). Doing so reveals that, the majority of the fluxes from $\mathrm{BNR}$ were $\mathrm{CO}_{2}(86 \%)$, followed by $\mathrm{N}_{2} \mathrm{O}(11 \%)$, and $\mathrm{CH}_{4}$

(3\%). When comparing GHG fluxes from BNR to other sources of GHGs at the Field's Point WWTP in terms of $\mathrm{CO}_{2}$ equivalence, BNR is responsible for approximately $12 \%$ of the total GHG emissions (Table 3).

While it was not the intent of this study to distinguish the source of influent carbon as biogenic or anthropogenic, one recent study using stable radiocarbon isotope signatures to determine the origin of $\mathrm{CO}_{2}$ has shown that up to $6 \%$ of influent total organic carbon may be released as $\mathrm{CO}_{2}$ emissions of fossil origin (Law et al. 2013). 
As the largest emissions in this study were from $\mathrm{CO}_{2}$, future studies that investigate the source of influent carbon to the WWTP will be important.

The IPCC emission factor is the current accepted method for estimating $\mathrm{N}_{2} \mathrm{O}$ emissions from WWTPs. However, the large variation in GHG emissions from different BNR methods makes it difficult to apply a single emission factor. The IPCC reports an $\mathrm{N}_{2} \mathrm{O}$ emission factor of $7 \mathrm{~g} \mathrm{~N}_{2} \mathrm{O}$ person $^{-1} \mathrm{yr}^{-1}$ for BNR processes (Ahn et al., 2010; Doorn et al., 2006). The average for our study was $9 \mathrm{~g} \mathrm{~N}_{2} \mathrm{O}$ person ${ }^{-1} \mathrm{y}^{-1}$ but ranged from 1 to $32 \mathrm{~g} \mathrm{~N}_{2} \mathrm{O}$ person ${ }^{-1} \mathrm{y}^{-1}$. Another study that measured $\mathrm{N}_{2} \mathrm{O}$ fluxes from 12 BNR systems throughout the U.S. reported $\mathrm{N}_{2} \mathrm{O}$ per capita emission factors ranging from 0.28 to $92 \mathrm{~g} \mathrm{~N}_{2} \mathrm{O}$ person ${ }^{-1} \mathrm{y}^{-1}$, up to an order of magnitude higher than the one suggested by the IPCC (Ahn et al., 2010). While the average $\mathrm{N}_{2} \mathrm{O}$ emission factor of this study was similar in magnitude to that reported by the IPCC, it is clear that the factor can vary widely even within the same WWTP. Therefore, further studies are needed to determine what environmental factors may be important in constraining this variation so that $\mathrm{N}_{2} \mathrm{O}$ emissions from WWTPs can be properly estimated.

\section{Conclusions}

This was the first study to examine $\mathrm{N}_{2} \mathrm{O}, \mathrm{CH}_{4}$, and $\mathrm{CO}_{2}$ emissions simultaneously from an IFAS BNR system in the U.S. Although large temporal and spatial variability of all three GHG fluxes was observed, the $\mathrm{N}_{2} \mathrm{O}$ and $\mathrm{CH}_{4}$ fluxes were small compared to those reported for other types of BNR methods and relative to the influent $\mathrm{N}$ and COD. Further, efforts to reduce emissions should focus on the Aerated IFAS zone where the highest fluxes and estimated production was observed. As the 
majority of the fluxes were from $\mathrm{CO}_{2}$, future studies will need to discern the portion of $\mathrm{CO}_{2}$ emissions that are biogenic or anthropogenic.

- Fluxes of all three $\mathrm{GHGs}\left(\mathrm{N}_{2} \mathrm{O}, \mathrm{CH}_{4}\right.$, and $\left.\mathrm{CO}_{2}\right)$ varied by 3 orders of magnitude over the course of the one year study

- On average in terms of $\mathrm{CO}_{2}$ equivalence, the majority of the fluxes were from $\mathrm{CO}_{2}$ (4312 tonne $\left.\mathrm{CO}_{2} \mathrm{y}^{-1}\right)$ rather than $\mathrm{N}_{2} \mathrm{O}\left(522\right.$ tonne $\left.\mathrm{CO}_{2} \mathrm{y}^{-1}\right)$ and $\mathrm{CH}_{4}\left(159\right.$ tonne $\mathrm{CO}_{2}$ $\left.\mathrm{y}^{-1}\right)$

- Only 0.01 to $0.34 \%$ of influent $\mathrm{N}$ is released as $\mathrm{N}_{2} \mathrm{O}$ and 0.02 to $0.13 \%$ of influent COD is released as $\mathrm{CH}_{4}\left(\mathrm{~kg} \mathrm{CH}_{4} / \mathrm{kg}\right.$ influent COD)

- There were significant positive linear relationships between $\mathrm{CH}_{4}$ and $\mathrm{CO}_{2}$ fluxes in the Aerated IFAS and Re-Aeration zones and $\mathrm{N}_{2} \mathrm{O}$ and $\mathrm{CO}_{2}$ fluxes in the Pre-Anoxic zone

- The largest emissions and estimated production were from the Aerated IFAS zone

- BNR is responsible for approximately $12 \%$ of the total GHG fluxes for the Field's Point WWTP 
Table 1. Average and standard deviation of characteristics and operating conditions of Tank 1 of the IFAS BNR system during flux measurement dates. (A) Characteristics and operating conditions for which there is only one measurement location within the IFAS BNR tank. For all variables (except Total Nitrogen (TN) removed), data was collected every 10 sec. and the average for the morning hours during which flux measurements were made is shown. WW = wastewater DO=Dissolved Oxygen SVI=Sludge Volume Index (B) Data that was collected from same locations as flux measurements ( $\mathrm{n}=3$ for each zone). For variables that included data below the detection limit, the non-parametric Kaplan-Meier method was used to determine the mean and standard deviation.

(A)

\begin{tabular}{|c|c|c|c|c|}
\hline $\begin{array}{l}\text { Characteristic/ } \\
\text { Operating } \\
\text { Condition } \\
\text { with Unit }\end{array}$ & Summer 2014 & Fall & Winter & Summer 2015 \\
\hline WW Flow Rate (MGD) & $36.3 \pm 3.1$ & $38.3 \pm 7.4$ & $41.0 \pm 8.4$ & $44.7 \pm 12.3$ \\
\hline WW Temperature $\left({ }^{\circ} \mathrm{C}\right)$ & $19.6 \pm 0.5$ & $16.8 \pm 2.6$ & $13.5 \pm 2.5$ & $17.1 \pm 1.9$ \\
\hline Air Flow Rate (scfm) & $1739.9 \pm 120.4$ & $1435.1 \pm 198.4$ & $1519.1 \pm 121.7$ & $1629.1 \pm 143.7$ \\
\hline DO in IFAS Zone $(\mathrm{mg} / \mathrm{L})$ & $4.2 \pm 0.2$ & $3.7 \pm 0.9$ & $4.8 \pm 0.5$ & $5.5 \pm 0.2$ \\
\hline $\mathrm{SVI}(\mathrm{ml} / \mathrm{g})$ & $126.7 \pm 28.9$ & $173.5 \pm 28.3$ & $157 \pm 42.1$ & $172.3 \pm 39.8$ \\
\hline TN Removed (\%) & 85 & 78 & 59 & 79 \\
\hline
\end{tabular}

(B)

\begin{tabular}{lllllll}
\hline $\begin{array}{l}\text { Characteristic } \\
(\mathrm{mg} / \mathrm{L})\end{array}$ & Influent & Pre-Anoxic & IFAS & Post Anoxic & Re-Aeration & Outflow \\
\hline $\mathrm{NH}_{4}{ }^{+}$ & $17.41 \pm 8.22$ & $7.05 \pm 4.87$ & $3.72 \pm 3.54$ & $3.04 \pm 4.09$ & $2.61 \pm 4.12$ & $2.12 \pm 3.39$ \\
$\mathrm{NO}_{3}{ }^{-}$ & $0.55 \pm 0.66$ & $0.99 \pm 1.18$ & $2.04 \pm 1.49$ & $1.40 \pm 1.51$ & $1.34 \pm 1.26$ & $1.38 \pm 1.41$ \\
$\mathrm{NO}_{2}{ }^{-}$ & $0.08 \pm 0.01$ & $0.11 \pm 0.04$ & $0.12 \pm 0.04$ & $0.11 \pm 0.08$ & $0.10 \pm 0.04$ & $0.10 \pm 0.05$ \\
\hline
\end{tabular}


Table 2. Results of two way ANOVA and post hoc Tukey tests for each gas. Zones are abbreviated as Pre-Anoxic (AN1), IFAS (AR1), Post Anoxic (AN2), Re-Aeration (AR2). Seasons are abbreviated as Summer 2014 (S14), Fall (F), Winter (W), and Summer 2015 (S15). Letters indicate significant differences from Tukey HSD. Letters early in the alphabet indicate higher fluxes than letters later in the alphabet.

\begin{tabular}{|c|c|c|c|}
\hline & Zone & Season & Zone*Season \\
\hline $\mathrm{N}_{2} \mathrm{O}$ & $\begin{array}{l}\mathrm{F}(3,159)=155.9, \mathrm{p}<0.01 * \\
\text { Tukey HSD: } \\
\text { AN1 } \\
\text { AR1 } \\
\text { AN2 } \\
\text { AR2 }\end{array}$ & $\begin{array}{l}\mathrm{F}(3,159)=8.1, \mathrm{p}<0.01^{*} \\
\text { Tukey HSD: } \\
{\mathrm{S} 14^{\mathrm{c}}}^{\mathrm{c}} \\
\mathrm{F}^{\mathrm{a}, \mathrm{b}} \\
\mathrm{S} 15^{\mathrm{b}, \mathrm{c}}\end{array}$ & $\mathrm{F}(9,159)=2.1, \mathrm{p}=0.03^{*}$ \\
\hline $\mathrm{CH}_{4}$ & $\begin{array}{l}\mathrm{F}(3,158)=103.5, \mathrm{p}<0.01^{*} \\
\text { Tukey HSD: } \\
\text { AN1 } \\
\text { AR1 } \\
\text { AN2 } \\
\text { AR2 }\end{array}$ & $\begin{array}{l}\mathrm{F}(3,158)=8.1, \mathrm{p}<0.01^{*} \\
\text { Tukey HSD: } \\
\text { S14 } \\
\mathrm{F}^{\mathrm{a}} \\
\mathrm{W}^{\mathrm{b}} \\
\mathrm{S} 15^{\mathrm{b}}\end{array}$ & $\mathrm{F}(9,158)=5.5, \mathrm{p}<0.01 *$ \\
\hline $\mathrm{CO}_{2}$ & $\begin{array}{l}\mathrm{F}(3,162)=741.1, \mathrm{p}<0.01^{*} \\
\text { Tukey HSD: } \\
\text { AN1 } \\
\text { AR1 } \\
\text { AN2 } \\
\text { AR2 }\end{array}$ & $\begin{array}{l}\mathrm{F}(3,162)=4.3, \mathrm{p}<0.01 * \\
\text { Tukey HSD: } \\
\mathrm{S} 14^{\mathrm{a}} \\
\mathrm{F}^{\mathrm{a}, \mathrm{b}} \\
\mathrm{W}^{\mathrm{b}} \\
\mathrm{S} 15^{\mathrm{a}, \mathrm{b}}\end{array}$ & $\mathrm{F}(9,162)=2.6, \mathrm{p}<0.01 *$ \\
\hline
\end{tabular}


Table 3. Breakdown of total greenhouse gas (GHG) emissions for Field's Point wastewater treatment plant.

\begin{tabular}{lc}
\hline Source & $\begin{array}{c}\text { \% of WWTPs total } \\
\text { GHG emissions }\end{array}$ \\
\hline Electricity (fossil fuel-derived) (US EPA, 2014) & 6.8 \\
Electricity (renewable wind turbine) (US EPA, 2014) & 5.4 \\
Natural Gas Burned (US EPA, 2014) & 1.1 \\
$\begin{array}{l}\text { Estimated liquid fuel purchased (US EPA, 2014) } \\
\text { Sludge incinerated offsite (based on carbon balance, recovered } \\
\text { energy not accounted) }\end{array}$ & 0.4 \\
$\begin{array}{l}\text { Sludge landfilled (Sylvis, 2009) } \\
\text { Supplemental Carbon }\end{array}$ & 47.8 \\
$\begin{array}{l}\text { Direct Emissions from IFAS BNR measured in this study } \\
\text { (including } \mathrm{CO}_{2}, \mathrm{CH}_{4} \text {, and } \mathrm{N}_{2} \mathrm{O} \text { ) }\end{array}$ & 26.1 \\
\hline
\end{tabular}




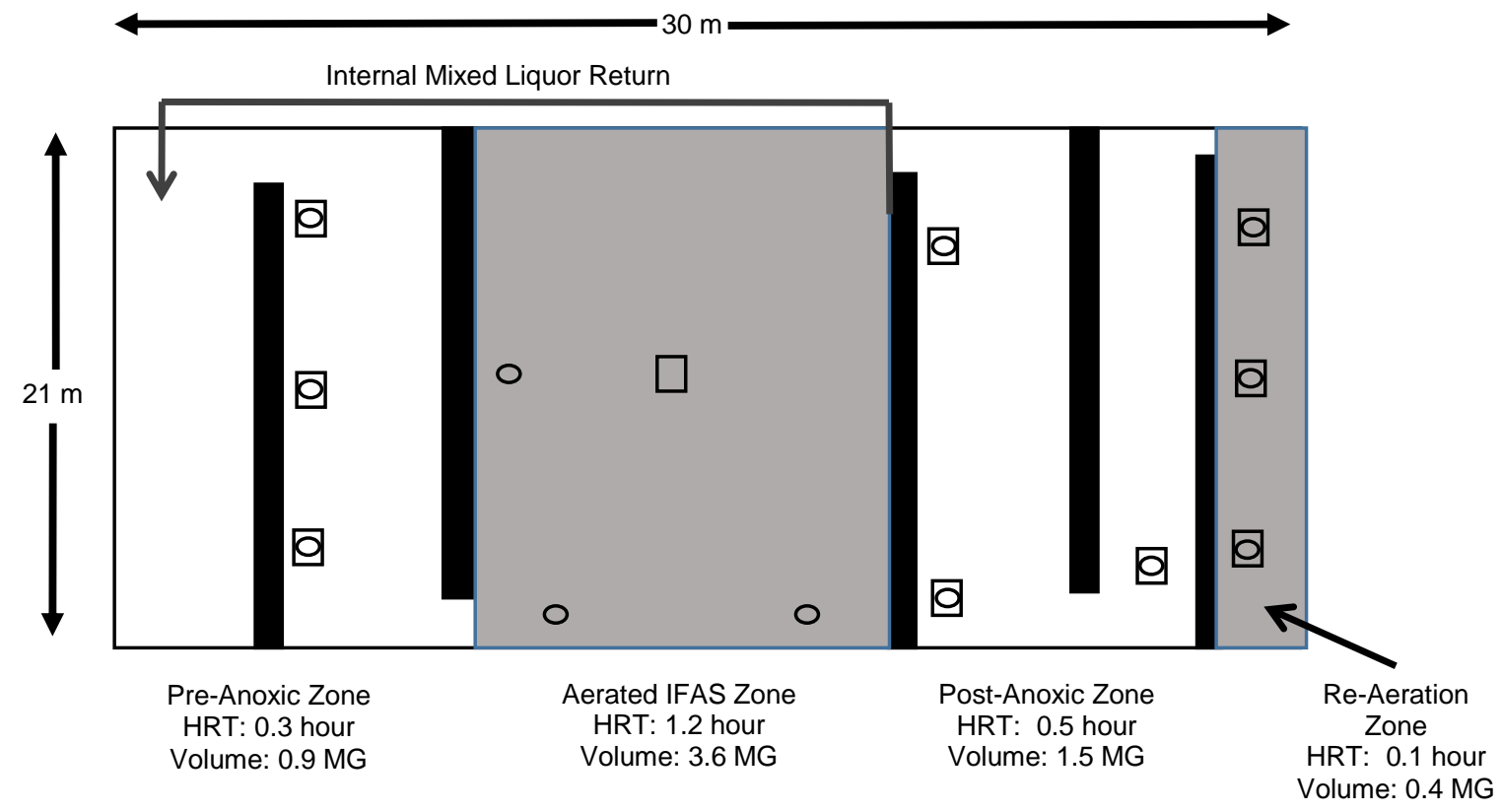

Figure 1. Aerial view of one of the ten Integrated Fixed Film Activated Sludge (IFAS) tanks at the Field's Point WWTP. The volume of each zone is reported in million gallons (MG) and the hydrologic retention time (HRT) is reported in hours. Rectangles represent locations of flux measurements and circles represent locations of water samples. Only one rectangle is shown in the Aerated IFAS Zone because all three flux measurements were collected from the same location. Black bars represent barriers and water flow is from left to right. 
A

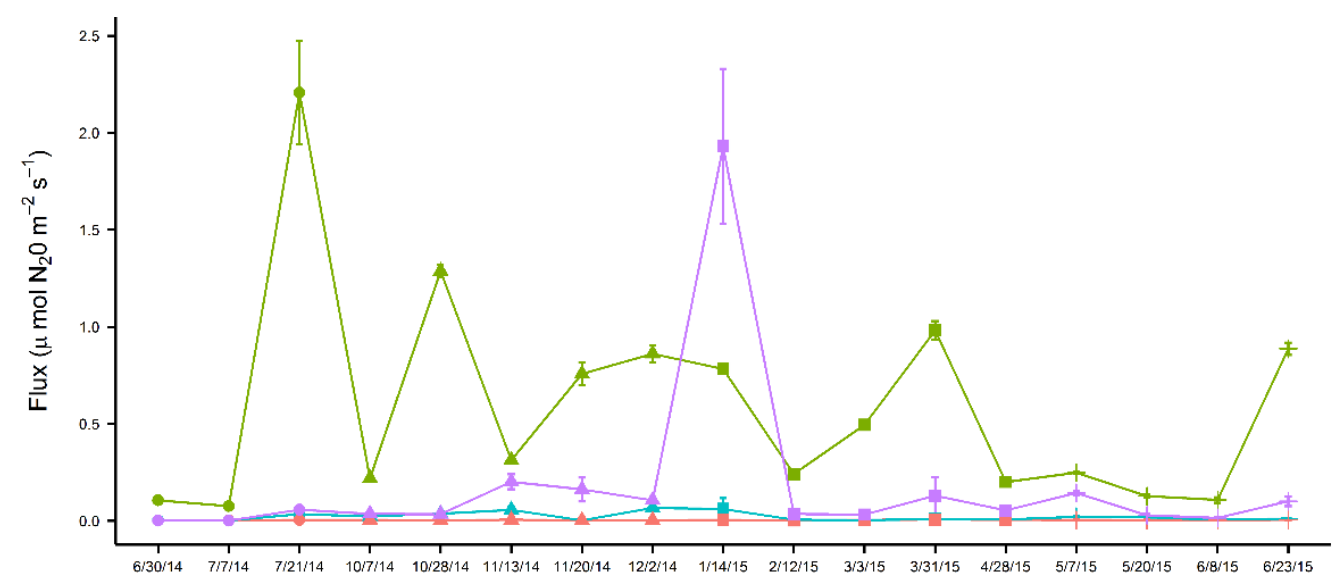

B

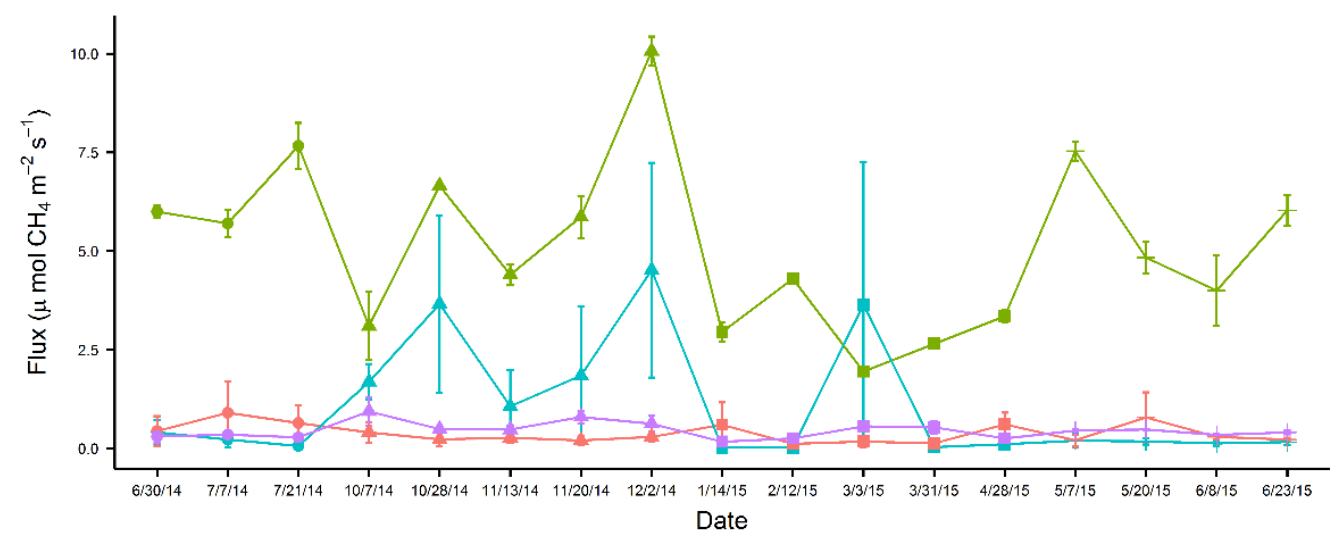

C

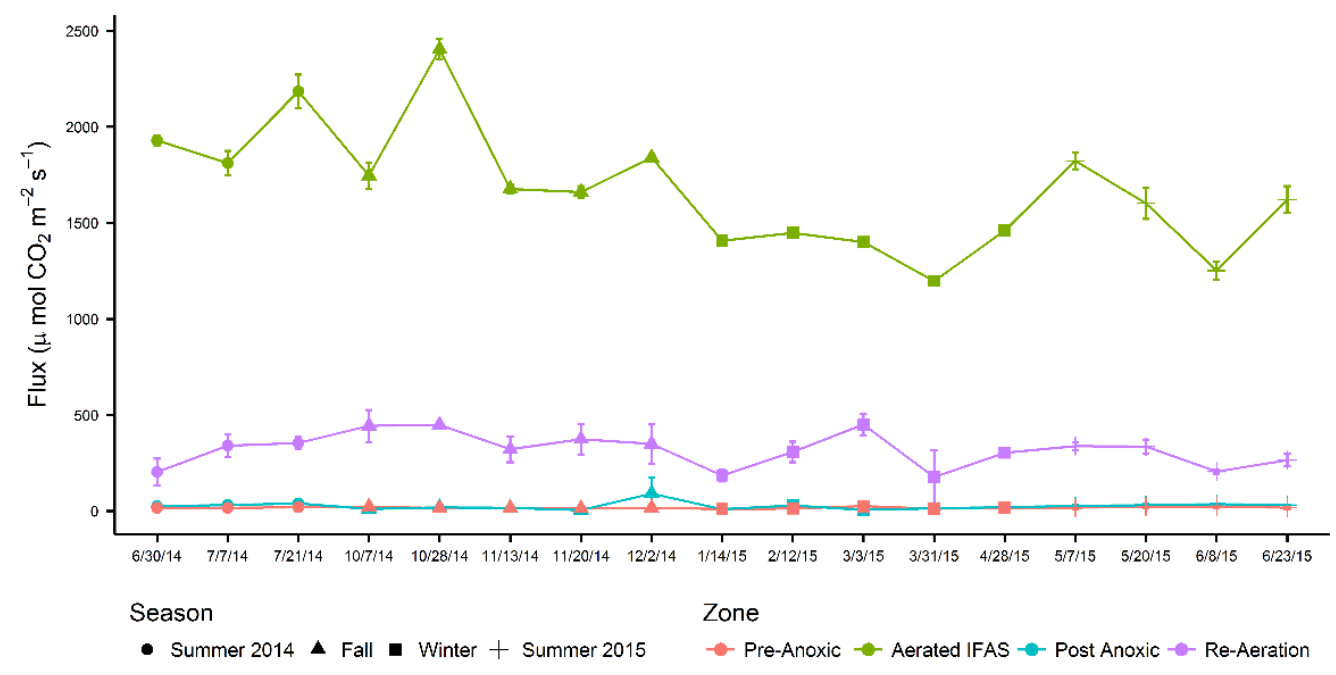

Figure 2. Average and standard error of $(A) \mathrm{N}_{2} \mathrm{O}$, (B) $\mathrm{CH}_{4}$, and $(\mathrm{C}) \mathrm{CO}_{2}$ fluxes for each zone on each date. Zones are represented by different colors and seasons are represented by different shapes. 
(A) Aerated IFAS

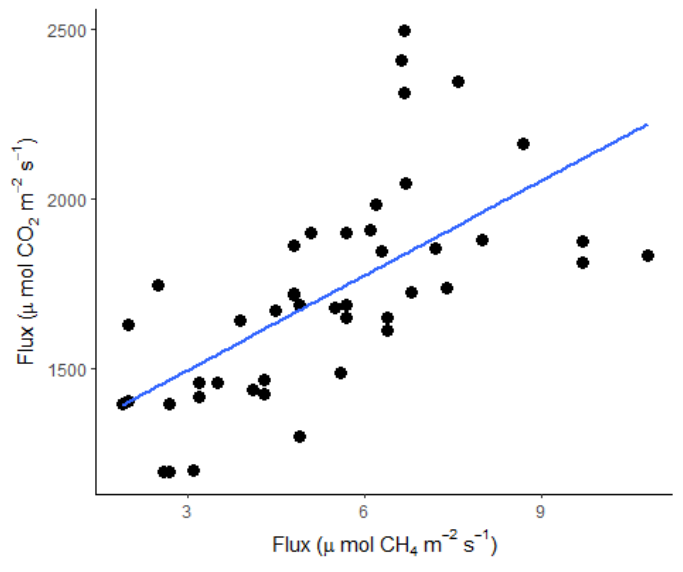

(B) Pre-Anoxic

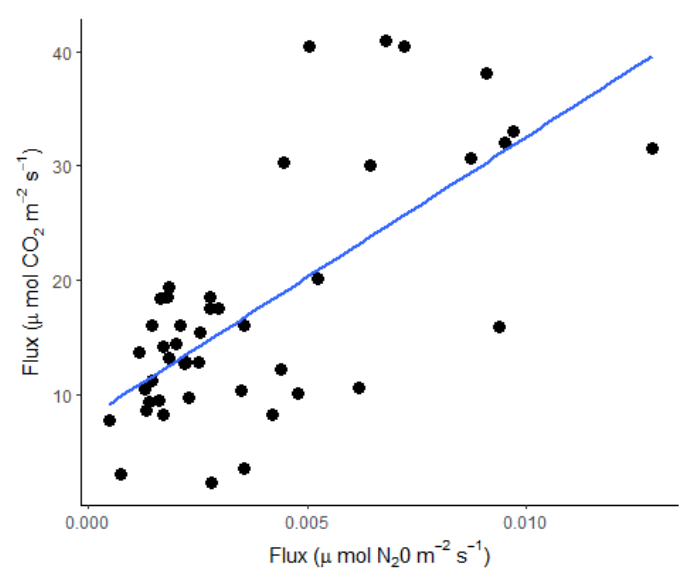

Figure 3. Significant regressions between gas fluxes. (A) $\mathrm{CH}_{4}$ and $\mathrm{CO}_{2}$ in Aerated IFAS and (B) $\mathrm{N}_{2} \mathrm{O}$ and $\mathrm{CO}_{2}$ in Pre-Anoxic. 
A

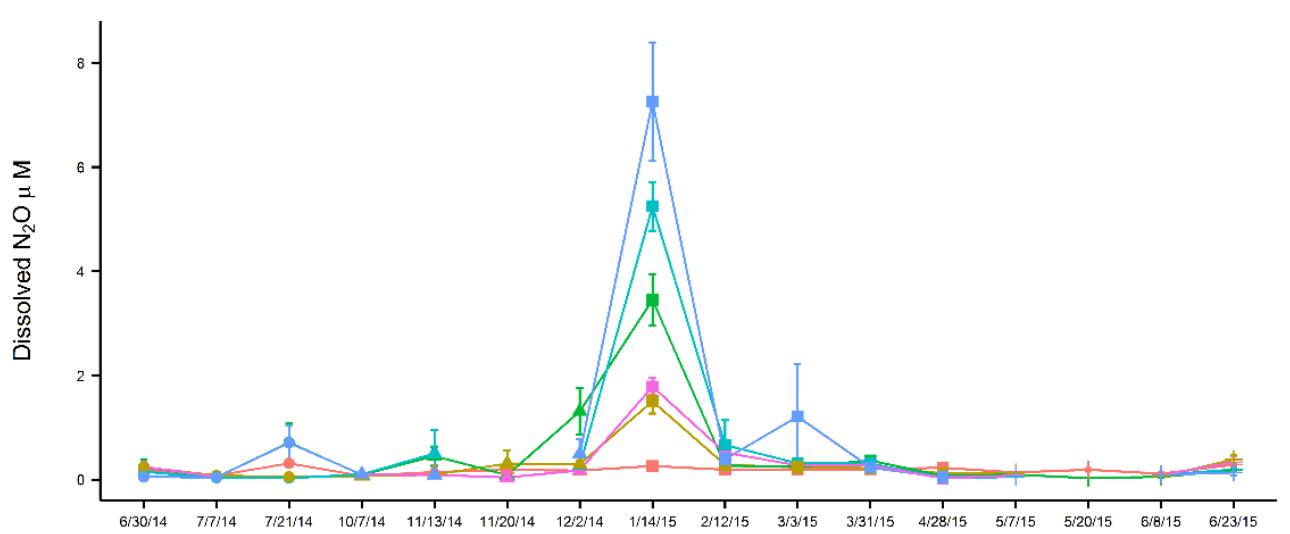

B

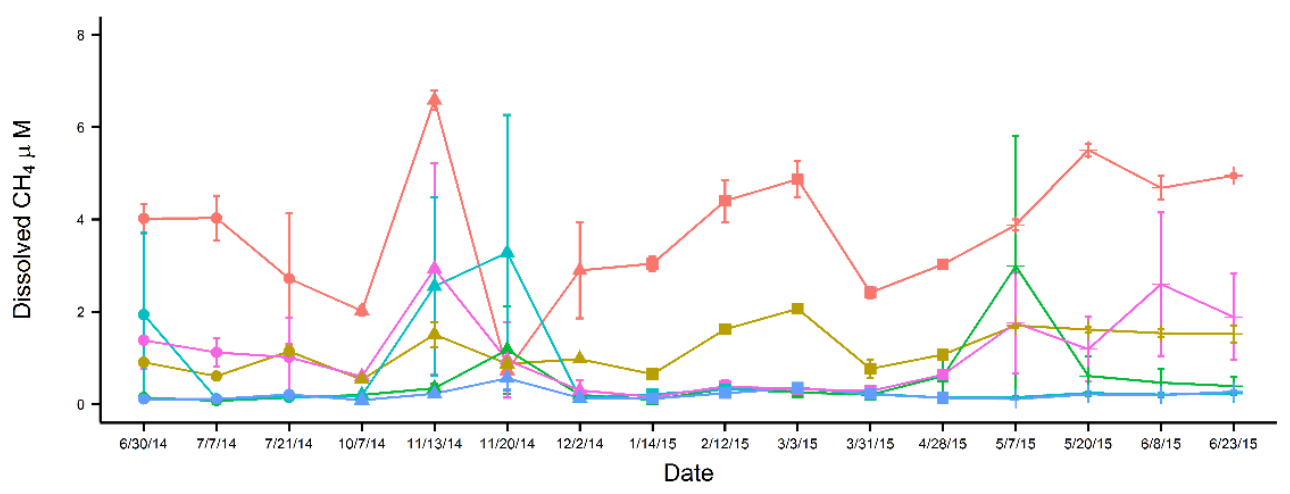

C

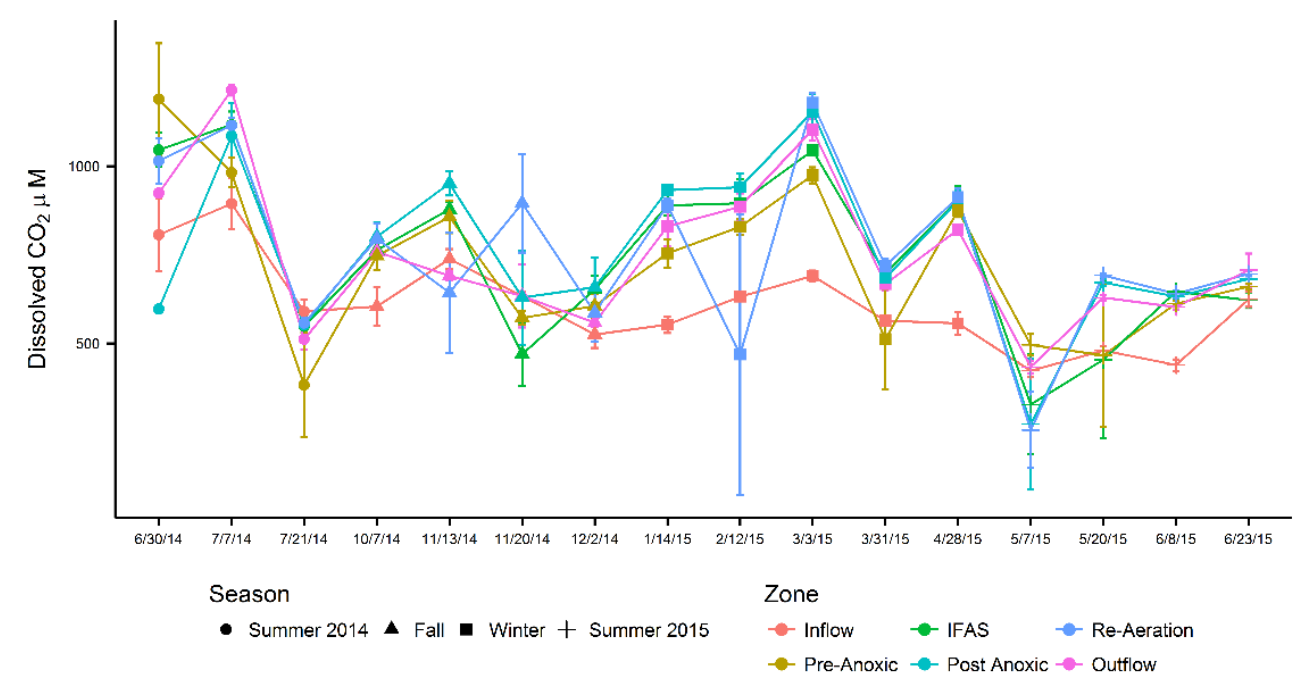

Figure 4. Average and standard error of (A) $\mathrm{N}_{2} \mathrm{O}$, (B) $\mathrm{CH}_{4}$, and (C) $\mathrm{CO}_{2}$ dissolved concentrations for each zone on each date. Zones are represented by different colors and seasons are represented by different shapes. 


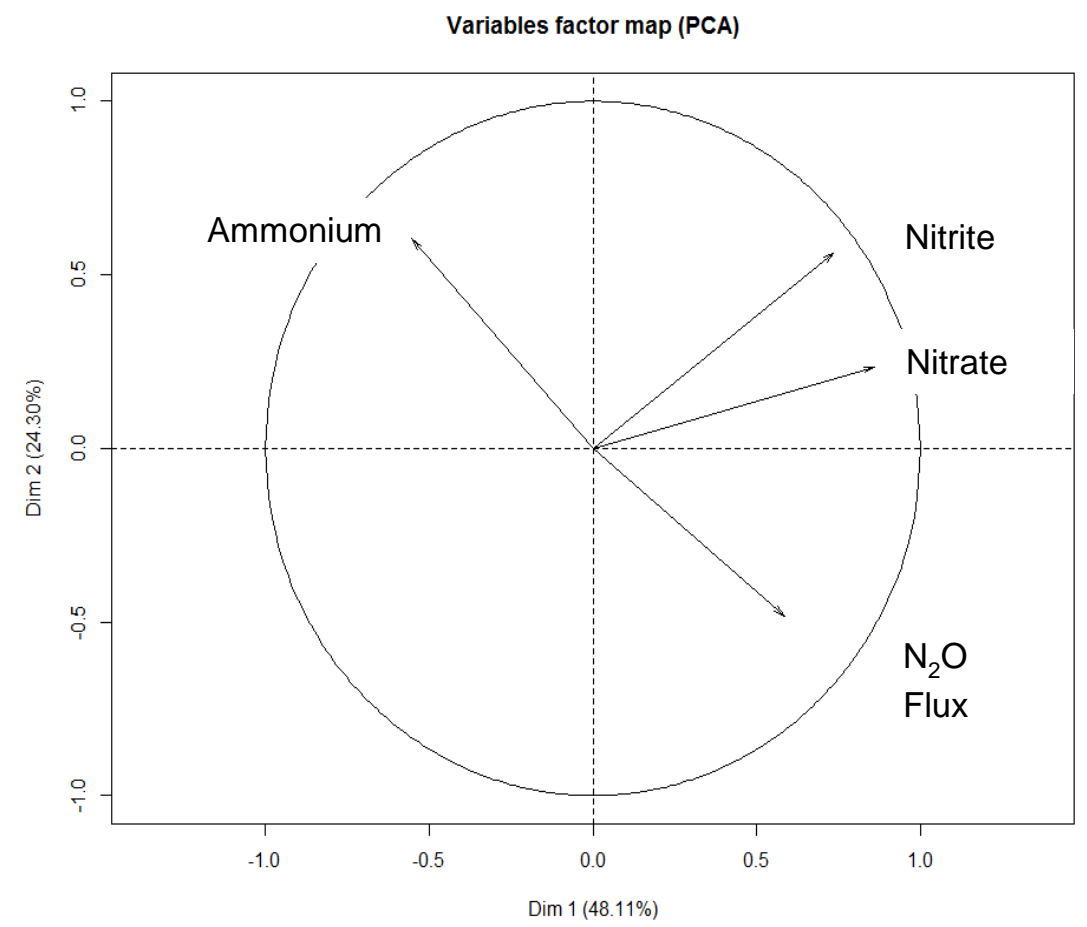

Figure 5. PCA for $\mathrm{N}_{2} \mathrm{O}$ flux including data from all zones on all dates. 


\section{Supplemental Information}

Table S1. Results of two way ANOVA and post hoc Tukey tests for concentration of each dissolved gas. Zones are abbreviated as Pre-Anoxic (AN1), IFAS (AR1), Post Anoxic (AN2), Re-Aeration (AR2). Seasons are abbreviated as Summer 2014 (S14), Fall (F), Winter (W), and Summer 2015 (S15). Letters indicate significant differences from Tukey HSD. Letters early in the alphabet indicate higher fluxes than letters later in the alphabet.

\begin{tabular}{|c|c|c|c|}
\hline & Zone & Season & Zone*Season \\
\hline $\mathrm{N}_{2} \mathrm{O}$ & $\mathrm{F}(5,211)=0.29, \mathrm{p}=0.92$ & $\begin{array}{l}\mathrm{F}(3,211)=11.00, \mathrm{p}<0.01^{*} \\
\text { Tukey HSD: } \\
\text { S14 } \\
\mathrm{F}^{\mathrm{b}} \\
\mathrm{W}^{\mathrm{a}} \\
\mathrm{S} 15^{\mathrm{b}}\end{array}$ & $\mathrm{F}(15,211)=0.76, \mathrm{p}=0.72$ \\
\hline $\mathrm{CH}_{4}$ & $\begin{array}{l}\mathrm{F}(5,241)=81.66, \mathrm{p}<0.01 * \\
\text { Tukey HSD: } \\
\text { I }^{\mathrm{A}} \\
\mathrm{AN} 1^{\mathrm{B}} \\
\mathrm{AR} 1^{\mathrm{C}} \\
\mathrm{AN} 2^{\mathrm{C}} \\
\mathrm{AR} 2^{\mathrm{C}} \\
\mathrm{O}^{\mathrm{B}}\end{array}$ & $\begin{array}{l}\mathrm{F}(3,241)=4.64, \mathrm{p}<0.01 * \\
\text { Tukey HSD: } \\
\text { S14 } \\
\mathrm{F}^{\mathrm{b}} \\
\mathrm{W}^{\mathrm{b}} \\
\mathrm{S} 15^{\mathrm{a}}\end{array}$ & $\mathrm{F}(15,241)=2.20, \mathrm{p}<0.01 *$ \\
\hline $\mathrm{CO}_{2}$ & $\begin{array}{l}\mathrm{F}(5,251)=4.19, \mathrm{p}<0.01^{*} \\
\text { Tukey HSD: } \\
\mathrm{I}^{\mathrm{B}} \\
\mathrm{AN} 1^{\mathrm{AB}} \\
\mathrm{AR}^{\mathrm{A}} \\
\mathrm{AN} 2^{\mathrm{A}} \\
\mathrm{AR}^{\mathrm{A}} \\
\mathrm{O}^{\mathrm{A}}\end{array}$ & $\begin{array}{l}\mathrm{F}(3,251)=30.79, \mathrm{p}<0.01^{*} \\
\text { Tukey HSD: } \\
\text { S14 } \\
\mathrm{F}^{\mathrm{b}} \\
\mathrm{W}^{\mathrm{a}} \\
\mathrm{S} 15^{\mathrm{c}}\end{array}$ & $\mathrm{F}(15,251)=1.02, \mathrm{p}=0.43$ \\
\hline
\end{tabular}


Table S2. Average production $\left(\mathrm{kg}_{\text {of }}\right.$ gas $\left.\mathrm{d}^{-1}\right)$ and standard error for the year long measurements for each gas by zone.

\begin{tabular}{lllll}
\hline $\mathrm{Gas}$ & Pre-Anoxic & IFAS & Post Anoxic & Re-Aeration \\
\hline $\mathrm{N} 2 \mathrm{O}$ & $-0.40 \pm 0.26$ & $0.90 \pm 0.42$ & $0.02 \pm 0.10$ & $0.23 \pm 0.16$ \\
$\mathrm{CH}_{4}$ & $-0.19 \pm 0.25$ & $1.27 \pm 0.57$ & $0.61 \pm 0.32$ & $-0.04 \pm 0.16$ \\
$\mathrm{CO}_{2}$ & $30.21 \pm 60.03$ & $970.99 \pm 68.73$ & $26.48 \pm 22.95$ & $185.62 \pm 31.90$ \\
\hline
\end{tabular}




\section{Diagram S1: Production calculation}

Abbreviations:

$\mathrm{G}=$ Generation $\left(\mathrm{kg} \mathrm{d}^{-1}\right)$

$\mathrm{E}=$ Flux $\left(\mathrm{kg} \mathrm{d}^{-1}\right)$

$\mathrm{C}=$ Dissolved concentration $\left(\mathrm{kg} \mathrm{m}^{-3}\right)$

$\mathrm{Q}=$ Water flow $\left(\mathrm{m}^{3} \mathrm{~d}^{-1}\right)$

$\mathrm{I}=$ Inflow

AN1 $=$ Pre-Anoxic

$\mathrm{AR} 1=\mathrm{IFAS}$

AN2 $=$ Post Anoxic

$\mathrm{AR} 1=\mathrm{Re}$-Aeration

RAS $=$ Returned activated sludge (Dissolved gas concentration was not measured in

RAS so concentration in

outflow from BNR was used. RAS flow was minor compared to I and IMLR

flow so affect should be minor.)

IMLR = Internal mixed liquor return

Equations:

$\mathrm{G}_{\mathrm{AN} 1}=\mathrm{E}_{\mathrm{AN} 1}+\mathrm{C}_{\mathrm{AN} 1}\left(\mathrm{Q}_{\mathrm{I}}+\mathrm{Q}_{\mathrm{RAS}}+\mathrm{Q}_{\mathrm{IMLR}}\right)-\mathrm{C}_{\mathrm{I}}\left(\mathrm{Q}_{\mathrm{I}}\right)-\mathrm{C}_{\mathrm{RAS}}\left(\mathrm{Q}_{\mathrm{RAS}}\right)-\mathrm{C}_{\mathrm{AR} 1}\left(\mathrm{Q}_{\mathrm{IMLR}}\right)$

$\mathrm{G}_{\mathrm{AR} 1}=\mathrm{E}_{\mathrm{AR} 1}+\mathrm{C}_{\mathrm{AR} 1}\left(\mathrm{Q}_{\mathrm{I}}+\mathrm{Q}_{\mathrm{RAS}}+\mathrm{Q}_{\mathrm{IMLR}}\right)-\mathrm{C}_{\mathrm{AN} 1}\left(\mathrm{Q}_{\mathrm{I}}+\mathrm{Q}_{\mathrm{RAS}}+\mathrm{Q}_{\mathrm{IMLR}}\right)$

$\mathrm{G}_{\mathrm{AN} 2}=\mathrm{E}_{\mathrm{AN} 2}+\mathrm{C}_{\mathrm{AN} 2}\left(\mathrm{Q}_{\mathrm{I}}+\mathrm{Q}_{\mathrm{RAS}}\right)-\mathrm{C}_{\mathrm{AR} 1}\left(\mathrm{Q}_{\mathrm{I}}+\mathrm{Q}_{\mathrm{RAS}}\right)$

$\mathrm{G}_{\mathrm{AR} 2}=\mathrm{E}_{\mathrm{AR} 2}+\mathrm{C}_{\mathrm{AR} 2}\left(\mathrm{Q}_{\mathrm{I}}+\mathrm{Q}_{\mathrm{RAS}}\right)-\mathrm{C}_{\mathrm{AN} 2}\left(\mathrm{Q}_{\mathrm{I}}+\mathrm{QRAS}_{\mathrm{R}}\right)$

Assumptions:

Solids are inert

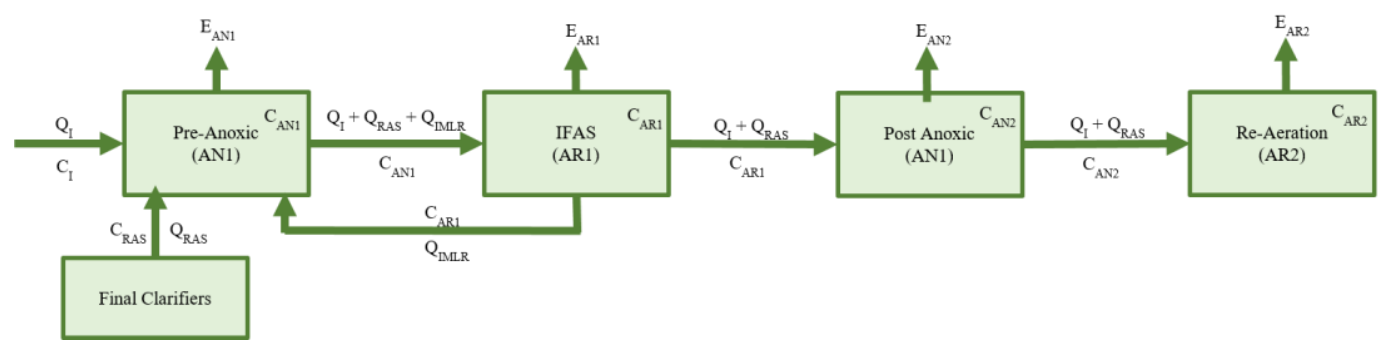




\section{Acknowledgments}

This work was supported by the Narragansett Bay Commission; the USDA National Institute of Food and Agriculture [Hatch Project 22986, 2011]; and the Rhode Island Science and Technology Advisory Council [05098, 2016]. The authors would like to thank the following for assistance in the field: Dave Aucoin, Isabella China, Brendan Cunha, Melanie Garate, Katie Lynch, Rose Martin, and Ryan Quinn. The authors would also like to thank Caleb Martin and Rose Martin for providing the

R scripts used for flux analysis. The authors would also like to thank Gavino Puggioni for his assistance with statistical analysis. 


\section{References}

Aboobakar, A., Cartmell, E., Stephenson, T., Jones, M., Vale, P., Dotro, G., 2013. Nitrous oxide emissions and dissolved oxygen profiling in a full-scale nitrifying activated sludge treatment plant. Water Res. 47, 524-534. doi:10.1016/j.watres.2012.10.004

Aboobakar, A., Jones, M., Vale, P., Cartmell, E., Dotro, G., 2014. Methane Emissions from Aerated Zones in a Full-Scale Nitrifying Activated Sludge Treatment Plant. Water. Air. Soil Pollut. 225. doi:10.1007/s11270-013-1814-8

Ahn, J.H., Kim, S., Park, H., Katehis, D., Pagilla, K., Chandran, K., 2010. Spatial and Temporal Variability in Atmospheric Nitrous Oxide Generation and Emission from Full-Scale Biological Nitrogen Removal and Non-BNR Processes. Water Environ. Res. 82, 2362-2372. doi:10.2175/106143010X12681059116897

Bao, Z., Sun, S., Sun, D., 2016. Assessment of greenhouse gas emission from A/O and SBR wastewater treatment plants in Beijing, China. Int. Biodeterior. Biodegrad. 108, 108-114. doi:10.1016/j.ibiod.2015.11.028

Bao, Z., Sun, S., Sun, D., 2015. Characteristics of direct $\mathrm{CO}_{2}$ emissions in four fullscale wastewater treatment plants. Desalination Water Treat. 54, 1070-1079. doi:10.1080/19443994.2014.940389

Brotto, A.C., Kligerman, D.C., Andrade, S.A., Ribeiro, R.P., Oliveira, J.L.M., Chandran, K., de Mello, W.Z., 2015. Factors controlling nitrous oxide emissions from a full-scale activated sludge system in the tropics. Environ. Sci. Pollut. Res. 22, 11840-11849. doi:10.1007/s11356-015-4467-х 
Carollo, 2012. City of Palo Alto Long Range Facilities Plan for the Regional Water Quality Control Plant: Final Report.

Czepiel, P.M., Crill, P.M., Harriss, R.C., 1993. Methane emissions from municipal wastewater treatment processes. Environ. Sci. Technol. 27, 2472-2477.

Doorn, M., Towprayoon, S., Vieira, S., Irving, W., Palmer, C., Pipatti, R., Wang, C., 2006. Ch. 6 Wastewater Treatment and Discharge, in: 2006 IPCC Guidelines for National Greenhouse Gas Inventories.

Eddy, I.M.\&, Tchobanoglous, G., Stensel, H.D., Tsuchihashi, R., Burton, F., 2013. Wastewater Engineering: Treatment and Resource Recovery, 5 edition. ed. McGraw-Hill Education, New York, NY.

Gray, N.D., Miskin, I.P., Kornilova, O., Curtis, T.P., Head, I.M., 2002. Occurrence and activity of Archaea in aerated activated sludge wastewater treatment plants. Environ. Microbiol. 4, 158-168.

Grote, B., 2010. Biological nutrient removal (BNR) technology in new and upgraded WWTPS, in: the35th Annual Qld Water Industry Operations Workshop Community Sports Centre, CQ University, Rockhampton.

Guisasola, A., Sharma, K.R., Keller, J., Yuan, Z., 2009. Development of a model for assessing methane formation in rising main sewers. Water Res. 43, 2874-2884. doi:10.1016/j.watres.2009.03.040

Helsel, D., 2011. Statistics for Censored Environmental Data Using Minitab and R, 2nd Edition, Second. ed. John Wiley \& Sons. 
Howarth, R., Anderson, D., Cloern, J., Elfring, C., Hopkinson, C., Lapointe, B., Malone, T., Marcus, N., McGlathery, K., Sharpley, A., Walker, D., 2000. Nutrient Pollution of Coastal Rivers, Bays, and Seas. Issues Ecol. 7, 1-16.

JMP, 1989. . SAS Institute Inc., Cary, NC.

Kong, Q., Wang, Z., Niu, P., Miao, M., 2016. Greenhouse gas emission and microbial community dynamics during simultaneous nitrification and denitrification process. Bioresour. Technol. 210, 94-100. doi:10.1016/j.biortech.2016.02.051

Lammers, S., Suess, E., 1994. An improved head-space analysis method for methane in seawater. Mar. Chem. 47, 115-125.

Law, Y., Ye, L., Pan, Y., Yuan, Z., 2012. Nitrous oxide emissions from wastewater treatment processes. Philos. Trans. R. Soc. B Biol. Sci. 367, 1265-1277. doi:10.1098/rstb.2011.0317

Lens, P., Poorter, M., Cronenberg, C., Verstraete, W., 1995. Sulfate Reducing and Methane Producing Bacteria in Aerobic Wastewater Treatment Systems. Water Res. 29, 871-880.

Mello, W.Z. de, Ribeiro, R.P., Brotto, A.C., Kligerman, D.C., Piccoli, A. de S., Oliveira, J.L., 2013. Nitrous oxide emissions from an intermittent aeration activated sludge system of an urban wastewater treatment plant. Quím. Nova 36, 16-20.

Picarro Inc., 2015. Picarro G2508 CRDS Analyzer Datasheet.

R Core Team, 2013. R: A language and environment for statistical computing. Foundation for Statistical Computing, Vienna, Austria.

Ren, Y., Wang, J., Xu, L., Liu, C., Zong, R., Yu, J., Liang, S., 2015. Direct emissions of $\mathrm{N}_{2} \mathrm{O}, \mathrm{CO}_{2}$, and $\mathrm{CH}_{4}$ from $\mathrm{A} / \mathrm{A} / \mathrm{O}$ bioreactor systems: impact of influent $\mathrm{C} / \mathrm{N}$ 
ratio. Environ. Sci. Pollut. Res. 22, 8163-8173. doi:10.1007/s11356-015-44088

RI DEM, 2005. Plan for Managing Nutrient Loadings to Rhode Island Waters.

Sommer, J., Ciplak, G., Linn, A., Sumer, E., Benckiser, G., Ottow, J., 1998. Quantification of emitted and retained $\mathrm{N}_{2} \mathrm{O}$ in a municipal waste water treatment plant with activated sludge and nitrifying-denitrifying units. Agribiol. Res. 51, $59-73$.

Sümer, E., Weiske, A., Benckiser, G., Ottow, J.C.G., 1995. Influence of environmental conditions on the amount of $\mathrm{N}_{2} \mathrm{O}$ released from activated sludge in a domestic waste water treatment plant. Experientia 51, 419-422.

Sylvis, 2009. The Biosolids Emisions Assesment Model (BEAM): A Method for Determining Greenhouse Gas Emissions from Canadian Biosolids Management Practices. Final Report.

Tomaszek, J., Czarnota, J., 2015. A review of current knowledge on $\mathrm{N}_{2} \mathrm{O}$ emissions from WWTPs, in: Tomaszek, Koszelnik (Eds.), Progress in Environmental Engineering. Taylor \& Francis Group, London.

US EPA, 2014. Emission Factors for Greenhouse Gas Inventories.

US EPA, 2013. Inventory of US Greenhouse Gas Emissions and Sinks: 1990 - 2011. EPA 430-R-13-001.

Wang, J., Zhang, J., Xie, H., Qi, P., Ren, Y., Hu, Z., 2011. Methane emissions from a full-scale A/A/O wastewater treatment plant. Bioresour. Technol. 102, 54795485. doi:10.1016/j.biortech.2010.10.090 
Weiss, R.F., 1974. Carbon Dioxide in Water and Seawater: The Solubility of a NonIdeal Gas. Mar. Chem. 2, 203-215.

Weiss, R.F., Price, B.A., 1980. Nitrous oxide solubility in water and seawater. Mar. Chem. 8, 347-359. doi:10.1016/0304-4203(80)90024-9

Yan, X., Li, L., Liu, J., 2014. Characteristics of greenhouse gas emission in three fullscale wastewater treatment processes. J. Environ. Sci. 26, 256-263. doi:10.1016/S1001-0742(13)60429-5

Zhu, G., Peng, Y., Li, B., Guo, J., Yang, Q., Wang, S., 2008. Biological Removal of Nitrogen from Wastewater. Rev. Environ. Contam. Toxicol. 192, 159-195. 


\section{CHAPTER 3}

\section{COMPARISON OF $\mathrm{N}_{2} \mathrm{O}$ EMISSIONS AND GENE ABUNDANCES BETWEEN NITROGEN REMOVAL SYSTEMS}

Submitted to Journal of Environmental Quality, March 2017

Authors: Elizabeth Quinn Brannon ${ }^{* 1}$; Serena M. Moseman-Valtierra ${ }^{1}$; Brittany V.

Lancellotti²; Sara K. Wigginton²; Jose A. Amador ${ }^{2}$; James C. McCaughey ${ }^{3}$; George W. Loomis ${ }^{4}$

\section{Affiliations:}

${ }^{1}$ Department of Biological Sciences, University of Rhode Island, Kingston, RI 02881, USA

${ }^{2}$ Laboratory of Soil Ecology and Microbiology, University of Rhode Island, Kingston, RI 02881, USA

${ }^{3}$ Narraganset Bay Commission, Providence, RI 02905, USA

${ }^{4}$ New England Onsite Wastewater Training Center, University of Rhode Island, Kingston, RI 02881

*Corresponding author email: ebrannon@my.uri.edu 


\begin{abstract}
Abbreviations
BNR, Biological Nitrogen Removal; WWTP, Wastewater Treatment Plant; OWTS, Onsite Wastewater Treatment System; amoA, ammonia monoxygenase; nosZ, nitrous oxide reductase
\end{abstract}

\title{
Keywords:
}

Integrated Fixed Film Activated Sludge (IFAS); Advanced Onsite Wastewater Treatment Systems (OWTS); amoA; nosZ

\section{Core Ideas:}

- First direct comparison of $\mathrm{N}_{2} \mathrm{O}$ emissions from $\mathrm{N}$ removal at a WWTP and advanced OWTS

- $\mathrm{N}_{2} \mathrm{O}$ emissions (mole/area) from OWTS were generally lower relative to BNR at WWTP

- $\mathrm{N}_{2} \mathrm{O}$ emissions normalized per capita and area were similar between WWTP and OWTS

- $\mathrm{N}_{2} \mathrm{O}$ emissions generally represented $<1 \%$ of $\mathrm{N}$ removed

- $\mathrm{N}_{2} \mathrm{O}$ emissions were not related to amoA or nos $Z$ gene abundance 


\section{Abstract}

Biological nitrogen removal (BNR) systems are increasingly used in the U.S. in both centralized wastewater treatment plants (WWTPs) and decentralized advanced onsite wastewater treatment systems (OWTS) to reduce $\mathrm{N}$ discharged in wastewater effluent. However, the potential for BNR systems to be sources of nitrous oxide $\left(\mathrm{N}_{2} \mathrm{O}\right)$, a potent greenhouse gas, needs to be evaluated to assess their environmental impact. We quantified and compared $\mathrm{N}_{2} \mathrm{O}$ emissions from BNR systems at a WWTP (Field's Point, Providence, RI) and three types of advanced OWTS (Orenco Advantex AX 20, SeptiTech Series D, and FAST) in 9 RI residences ( $n=3$ per type) using cavity ring-down spectroscopy. We also used quantitative PCR to determine the abundance of genes from nitrifying (amoA) and denitrifying (nosZ) microorganisms that may be producing $\mathrm{N}_{2} \mathrm{O}$ in these systems. Nitrous oxide fluxes ranged from $-4 \times 10^{-3}$ to $3 \times 10^{-}$ ${ }^{1} \mu \mathrm{mol} \mathrm{N} \mathrm{O} \mathrm{m}^{-2} \mathrm{~s}^{-1}$ and in general followed the order: centralized WWTP > Advantex $>$ SeptiTech > FAST. In contrast, when $\mathrm{N}_{2} \mathrm{O}$ emissions were normalized by population served and area of treatment tanks all systems had overlapping ranges. In general, the emissions of $\mathrm{N}_{2} \mathrm{O}$ accounted for a small fraction $(<1 \%)$ of $\mathrm{N}$ removed. There was no significant relationship between the abundance of nos $Z$ or amoA genes and $\mathrm{N}_{2} \mathrm{O}$ emissions. This preliminary analysis highlights the need to evaluate $\mathrm{N}_{2} \mathrm{O}$ emissions from wastewater systems as a wider range of technologies are adopted. In addition, a better understanding of the mechanisms of $\mathrm{N}_{2} \mathrm{O}$ emissions will allow us to better manage systems to minimize emissions. 


\section{Introduction}

Humans substantially modify global nitrogen $(\mathrm{N})$ cycles by industrially fixing $\mathrm{N}$ for fertilizer and ultimately releasing reactive $\mathrm{N}$ back to the environment through various mechanisms, including wastewater treatment. The continued growth of human population will lead to further increases in excess reactive $\mathrm{N}$, increasing the need for $\mathrm{N}$ remediation (Galloway et al., 2003). In recent years, remediation has focused on upgrading centralized wastewater treatment plants (WWTPs) to include biological nitrogen removal (BNR). Since one in five homes in the U.S. are serviced by conventional onsite wastewater treatment systems (OWTS) (United States Environmental Protection Agency (US EPA), 2013) they can also be large sources of N (Zhu et al., 2008; US EPA, 2015). The use of OWTS can be advantageous relative to centralized WWTPs, as they recharge groundwater supplies, require less infrastructure and have lower energy costs (US EPA, 2013). In order to ameliorate N inputs to the environment, conventional OWTS are also being upgraded to advanced OWTS that include BNR.

Although BNR systems at WWTPs and OWTS vary in design, all employ nitrifying (conversion of ammonium to nitrate) and denitrifying (conversion of nitrate to nitrogen gas) bacteria in oxic and anoxic environments, respectively (Howarth et al., 2000). The systems are designed to remove $\mathrm{N}$ mainly in the form of $\mathrm{N}_{2}$ gas, the final product of denitrification. However, in addition to $\mathrm{N}_{2}$, the BNR process may produce substantial quantities of nitrous oxide $\left(\mathrm{N}_{2} \mathrm{O}\right)$, a greenhouse gas 265 times more potent than $\mathrm{CO}_{2}$ that can also deplete ozone in the stratosphere (Core Writing Team et al., 2014; Tomaszek and Czarnota, 2015). Nitrous oxide is produced by 
microbial $\mathrm{N}$ transformations including nitrification and denitrification. Nitrification can produce $\mathrm{N}_{2} \mathrm{O}$ as a by-product and denitrification can be both a source and sink of $\mathrm{N}_{2} \mathrm{O}$ (Wrage et al., 2001). Therefore, the abundance and biological activity of nitrifying and/or denitrifying bacteria is likely a key factor influencing the rates of these $\mathrm{N}$ transformations associated with $\mathrm{N}_{2} \mathrm{O}$ emissions.

Previous studies have documented the magnitude of $\mathrm{N}_{2} \mathrm{O}$ emissions relative to $\mathrm{N}$ removal rates from various types of BNR systems at centralized WWTPs, with emission factors (\% of $\mathrm{N}$ load released as $\mathrm{N}_{2} \mathrm{O}$ ) varying by over four orders of magnitude, 0.001 to $25.3 \%$ (Tomaszek and Czarnota, 2015). In contrast, only one study published values for $\mathrm{N}_{2} \mathrm{O}$ emissions from advanced OWTS designed to remove N (Todt and Dorsch 2015). Biological nitrogen removal at both WWTPs and OWTS will become increasingly important as the human population and wastewater production, continues to increase. Therefore, the magnitude of $\mathrm{N}_{2} \mathrm{O}$ emissions from BNR of both WWTPs and OWTS should be determined in order to evaluate the effectiveness of these systems in $\mathrm{N}$ remediation and their potential impacts on greenhouse gas emissions. In addition, insights regarding the microbial sources of $\mathrm{N}_{2} \mathrm{O}$ emissions will help to discern the potential mechanisms by which they may be mitigated through technological and operational changes to wastewater treatment systems, while striving to maximize $\mathrm{N}$ removal.

We quantified and compared $\mathrm{N}_{2} \mathrm{O}$ emissions from BNR at a centralized WWTP and three types of advanced OWTS (Advantex, SeptiTech, and FAST) in terms of instantaneous emissions, normalized per capita emissions, and emission factors ( $\%$ of $\mathrm{N}$ released as $\mathrm{N}_{2} \mathrm{O}$ ). We also quantified and compared amoA 
(nitrification) and nos $Z$ (denitrification) gene abundances and ratios from the same treatment systems to examine potential relationships between abundances of nitrifying and/or denitrifying bacteria and $\mathrm{N}_{2} \mathrm{O}$ emissions. A positive relationship between amoA abundance and $\mathrm{N}_{2} \mathrm{O}$ emissions would indicate that nitrification was likely responsible for the $\mathrm{N}_{2} \mathrm{O}$ emissions. A negative relationship between $\mathrm{N}_{2} \mathrm{O}$ emissions and $\operatorname{nos} Z$ would indicate that complete denitrification was a sink for $\mathrm{N}_{2} \mathrm{O}$ emissions. Understanding the mechanism (nitrification or denitrification) responsible for the $\mathrm{N}_{2} \mathrm{O}$ emissions may allow for operational changes to reduce $\mathrm{N}_{2} \mathrm{O}$ emissions while maintaining $\mathrm{N}$ removal.

\section{Methods}

\section{Study Sites and Measurement Locations}

The wastewater systems we examined were within the Greater Narragansett Bay watershed in Rhode Island, USA. Field's Point is a full-scale centralized WWTP serving 226,000 people in Providence, RI (Narragansett Bay Commission, 2017). The plant provides primary and secondary treatment for flows up to 77 million gallons per day (MGD) for combined sewer from domestic and industrial sources. Secondary treatment includes an Integrated Fixed Film Activated Sludge (IFAS) system for BNR. The IFAS system consists of 10 identical tanks, each with the following four main zones: (i) pre-anoxic, (ii) aerated IFAS, (iii) post-anoxic, and (iv) re-aeration. The aerated IFAS zone provides additional surface area for biofilm growth with the

inclusion of perforated high-density polyethylene cylinder media (25-mm dia., 10-mm 
length). Two $\mathrm{N}_{2} \mathrm{O}$ emission measurements and water samples were collected in each of the four zones of one IFAS tank. Water samples were collected from just below the water surface within 3 hours of the emission measurements.

We examined three of the most commonly used advanced OWTS technologies for BNR in RI: Orenco Advantex AX20 (textile media filter), BioMicrobics MicroFAST (fixed activated sludge treatment unit), and SeptiTech D Series (trickling filter). All OWTS were located in Jamestown, RI, with measurements made in three systems per technology (9 systems total). All systems have an anoxic compartment for denitrification (SP1) and an oxic compartment for nitrification (SP2). We made one $\mathrm{N}_{2} \mathrm{O}$ emission measurement and collected one water sample from each compartment (SP1 and SP2) in each system per sampling event. The access riser lid to the systems was removed to allow trapped gases to vent for approximately 10 minutes before the emission measurement was made. Water samples were collected from the middle of the water column immediately after emission measurements were made.

Nitrous oxide emission measurements and wastewater samples were collected from each system once in June and once in October, resulting in a total of 16 measurements for the WWTP and 36 for the OWTS. Logistical constraints prevented sampling from all sites on the same day. Thus, sampling of all systems took place within two weeks of each other during each round of measurements.

\section{Nitrous Oxide Emission Measurements}

At each study site $\mathrm{N}_{2} \mathrm{O}$ emission measurements were made using a closed chamber connected to a real-time cavity ring down spectroscopy analyzer (Picarro G2508, 
Santa Clara, CA) capable of measuring $\mathrm{N}_{2} \mathrm{O}$ approximately every two seconds (detailed in Brannon et al., 2016). At the centralized WWTP we used a transparent (polypropylene) rectangular floating chamber (height: $0.3 \mathrm{~m}$, width: $0.3 \mathrm{~m}$, length: 0.5 m). At the OWTS sites, an open-bottom PVC cylindrical chamber (i.d.: $0.13 \mathrm{~m}$, length: $0.40 \mathrm{~m}$ ) was placed on the water so that the bottom was submerged $7.5 \mathrm{~cm}$ below the surface. The chamber was kept level and at a constant depth using a stabilizing bar that rested across the top of the access port. The chamber was deployed for between 3 and 10 minutes at all sites.

Gas emissions from all zones at the centralized WWTP, except the aerated IFAS zone, and both compartments of all OWTS sites were calculated as outlined in Mello et al. (2013) for non-aerated stages. Due to the high aeration rates used in the IFAS zone at the centralized WWTP ( 1457 standard cubic feet per minute (scfm)), emissions from this zone were calculated using a method for aerated stages which accounts for the effects of air flow (Mello et al., 2013).

The statistical significance of each gas emission was determined following Brannon et al. (2016), with the exception that, if the p-value of the linear regression of concentration over time was not statistically significant, then the flux was reported as zero. There were four measurements, two each from two different Advantex systems, that we were not able to calculate the emission value for because the concentration of another gas $\left(\mathrm{CH}_{4}\right)$ measured by the analyzer exceeded the upper range of the analyzer and interfered with analysis of the target species $\left(\mathrm{N}_{2} \mathrm{O}\right)$.

For comparison across systems, $\mathrm{N}_{2} \mathrm{O}$ emissions were normalized by population and area of the treatment tank $\left(\mathrm{mg} \mathrm{N} \mathrm{N}_{2} \mathrm{O}\right.$ capita $\left.{ }^{-1} \mathrm{~d}^{-1}\right)$ according to supplementary 
equations 1 (WWTP) and 2 (OWTS). Also, $\mathrm{N}_{2} \mathrm{O}$ emission factors (mass/mass) were computed by normalizing the flux to the quantity of $\mathrm{N}$ removed, according to supplementary equations 3 (WWTP) and 4 (OWTS). For the IFAS BNR system at the centralized WWTP one normalized emission value and one emission factor (mass/mass) was calculated for each date that included the total emissions for the IFAS system (all four zones of all 10 tanks). For the OWTS one normalized emission value and one emission fraction (mass/mass) was calculated for each house on each date $(n=6$ per technology).

\section{DNA Extraction}

Genomic DNA was extracted from water samples from the WWTP and OWTS. For the centralized WWTP samples, approximately $50 \mathrm{~mL}$ of sample was centrifuged at 3,000 $\mathrm{xg}$ for 15 minutes and the solids were used for DNA extraction using a PowerSoil DNA Isolation Kit (MoBio Laboratories, Inc., Carlsbad, CA). For the OWTS approximately $100 \mathrm{~mL}$ of sample was vacuum filtered onto sterile 0.22 $\mu \mathrm{m}$-pore size nitrocellulose membrane filters (Millipore Corporation, Darmstadt, Germany). Non-sterile filters were used for 12 samples, but blanks were included to check for contamination. The filter was used for DNA extraction using a PowerWater DNA Isolation Kit (MoBio Laboratories, Inc., Carlsbad, CA). The quality and concentration $(\mathrm{ng} / \mu \mathrm{L})$ of all extracted DNA was determined with a NanoDrop 8000 UV-Vis spectrophotometer (Thermo Fisher Scientific, Wilmington, DE) and stored at $-20^{\circ} \mathrm{C}$ or below until qPCR analysis. 


\section{Quantitative PCR ( $q P C R)$}

The concentrations of ammonia monooxygenase genes (amoA) and nitrous oxide reductase genes (nosZ) were quantified by real-time polymerase chain reaction (qPCR) using the primer sets developed by Geets et al. (2007) and Junier et al. (2009) (Supplementary Table S1). Individual standard curves were prepared for each gene from a sample that presented one clear band of the correct size after PCRamplification and was purified with a QIAquick PCR Purification Kit (Qiagen, Germantown, MD). The concentration $(\mathrm{ng} / \mu \mathrm{L})$ of purified products that served as standards was determined using an Invitrogen Qubit 2.0 fluorometer (Thermo Fisher Scientific, Carlsbad, CA) and converted to copies $/ \mu$ L. Ten-fold serial dilutions of the purified product were prepared from $10^{7}$ to $10^{1}$ copy numbers $/ \mu \mathrm{L}$.

The real-time PCR quantification was carried out on a Lightcycler 480 (Roche Diagnostics, Indianapolis, IN) with SYBR Green I Master (Roche Diagnostics, Indianapolis, IN). All standards and samples were analyzed in triplicate and at least one triplicate negative control containing no template DNA was analyzed in each qPCR run to detect contamination. For both genes a total reaction volume of $20 \mu \mathrm{L}$ was used, which contained $5 \mu \mathrm{L}$ DNA template (for amoA WWTP samples were diluted one order of magnitude), $0.5 \mu \mathrm{L}$ of each primer, $10 \mu \mathrm{L}$ of the SYBR Green I Master, and $4 \mu \mathrm{L}$ of water. The thermocycler settings for $n o s Z$ were as follows: $94^{\circ} \mathrm{C}$ for $10 \mathrm{~min}, 45$ cycles at $94^{\circ} \mathrm{C}$ for $10 \mathrm{sec}, 61^{\circ} \mathrm{C}$ for $15 \mathrm{sec}$, and $72^{\circ} \mathrm{C}$ for $20 \mathrm{sec}$. The thermocycler settings for $a m o A$ were as follows: $94^{\circ} \mathrm{C}$ for $10 \mathrm{~min}, 45$ cycles at $94^{\circ} \mathrm{C}$ for $10 \mathrm{sec}, 54^{\circ} \mathrm{C}$ for $10 \mathrm{sec}$, and $72^{\circ} \mathrm{C}$ for $14 \mathrm{sec}$. Amplification efficiencies for both genes ranged from 78 to $100 \%$. A melt curve was analyzed for every run and the 
qPCR product for one of each triplicate was examined on a $1 \%(w / v)$ ethidium bromide-stained agarose gel to confirm the amplification of a single product for both genes. In addition to concentration (copies $/ \mu \mathrm{L}$ ), the abundance of each gene (copies/ng nucleic acid) was calculated using the qPCR results and the total concentration of DNA.

\section{Wastewater Properties}

For WWTP samples, a subset of the water sample used for qPCR analysis was filtered $(0.45-\mu \mathrm{m}$-pore-size $)$ and the filtrate used to determine the concentration of $\mathrm{NH}_{4}$ using the phenolhypochlorite method (Solorzano, 1969) and nitrate using the dimethylphenol method (Hach Company, 2015). The surface pH (Seven Go Duo Pro, Metler Toledo, Columbus, OH) and DO (LDO Probe, HACH Model 57900-00, Loveland, $\mathrm{CO}$ ) were measured within 2 hours of the emission measurements. The water temperature was continuously measured in the IFAS zone only with a LDO probe (HACH Model 57900-00, Loveland, CO). The average water temperature during the time of the flux measurements is reported in Table S2.

For the OWTS samples, a Hanna Instruments HI9828 Multiparameter Meter (Woonsocket, RI) was used to determine wastewater $\mathrm{pH}, \mathrm{DO}$, and temperature in the

field in each compartment. A subset of the sample used for qPCR analysis was used to determine the concentration of ammonium, nitrate, and $\mathrm{BOD}_{5}$ as described in Lancellotti (2016). 


\section{Statistical Analysis}

We used linear regressions to examine relationships between $\mathrm{N}_{2} \mathrm{O}$ emissions and gene abundances and amoA/nos $\mathrm{Z}$ ratios; between $\mathrm{N}_{2} \mathrm{O}$ emissions and the wastewater properties; and gene abundances and amoA/nos $Z$ ratios and the wastewater properties. Two separate regressions were performed: one for nitrification zones (aerated IFAS and re-aerations zones for the WWTP and SP2 for the OWTS) and one for denitrification zones (pre-anoxic and post-anoxic zones for the WWTP and SP1 for the OWTS). Gene concentrations below the detection limit of 10 copies/ $\mu \mathrm{L}$ were assigned a value of zero. Wastewater properties below the detection limit were assigned a value of zero. All data were checked for normality and transformed when necessary. All statistical analyses were performed using JMP (Version 13, SAS Institute, Inc., Cary, NC, 1989 - 2007)

\section{Results and Discussion}

\section{Nitrous Oxide Emissions}

The largest $\mathrm{N}_{2} \mathrm{O}$ emissions at the WWTP were from the aerated IFAS zone and the post-anoxic zone, while emissions from the pre-anoxic and re-aeration zones were relatively low (Figure 1A). The emissions of $\mathrm{N}_{2} \mathrm{O}$ from the WWTP represented between 0.02 and $0.04 \%$ of $\mathrm{N}$ removed, which is in the lower end of the range $(0.001$ $-25.3 \%$ ) reported by studies from other types of BNR systems at WWTPs (Tomaszek and Czarnota, 2015).

Our study is the first to measure $\mathrm{N}_{2} \mathrm{O}$ emissions from advanced OWTS designed for $\mathrm{N}$ removal. The Advantex systems had the highest $\mathrm{N}_{2} \mathrm{O}$ emissions of the 
three OWTS (Figure 1A), and emissions were similar between SP1 (denitrification) and SP2 (nitrification) for all OWTS systems (Figure 1A). Similar to the WWTP, the $\mathrm{N}_{2} \mathrm{O}$ emissions from the SeptiTech and FAST OWTS represented a relatively small percent of the $\mathrm{N}$ removed $(0.0-4.4 \%)$. In contrast, the $\mathrm{N}_{2} \mathrm{O}$ emissions from the Advantex systems represented a much higher percent of the $\mathrm{N}$ removed $(0.05-21.00$ $\%)$. This suggests that conditions within the Advantex treatment train favor $\mathrm{N}_{2} \mathrm{O}$, rather than $\mathrm{N}_{2}$, production. For example, the Advantex systems had the lowest $\mathrm{pH}$ (6.4) (Supplementary Table S2). Previous studies have demonstrated that nosZ is sensitive to low $\mathrm{pH}(<6.5)$ resulting in reduced conversion of $\mathrm{N}_{2} \mathrm{O}$ to $\mathrm{N}_{2}$ (Law et al., 2012).

The emissions of $\mathrm{N}_{2} \mathrm{O}$ from the aerated IFAS and post-anoxic zones at the WWTP were higher than those from all three OWTS (Figure 1A). In contrast, emissions from the pre-anoxic and re-aeration zones at the WWTP were similar in magnitude to those from all three OWTS (Figure 1A). It is not surprising that the highest $\mathrm{N}_{2} \mathrm{O}$ emissions in this study are from the aerated IFAS zone of the WWTP, since it uses high air flow rates (on average $1638 \mathrm{scfm}$ ) compared to the OWTS (FAST: 17 - 25 scfm, SeptiTech: venture air intake, and Advantex: passive air diffusion). Higher air flow rates at the WWTP may cause higher $\mathrm{N}_{2} \mathrm{O}$ emissions due to mechanical stripping of dissolved $\mathrm{N}_{2} \mathrm{O}$. There was not a significant relationship between $\mathrm{N}_{2} \mathrm{O}$ and any of the wastewater properties in either the nitrification or denitrification components of these systems (data not shown).

Although $\mathrm{N}_{2} \mathrm{O}$ emissions were observed from all systems, a negative $\mathrm{N}_{2} \mathrm{O}$ flux (indicating uptake or consumption) was observed on 2 occasions ( 2 measurements in 
the WWTP re-aeration zone) out of 34 measurements total. While negative $\mathrm{N}_{2} \mathrm{O}$ fluxes have not been reported for BNR systems, they have been observed in soil (Chapuis-Lardy et al., 2007). It is generally assumed that heterotrophic denitrification is responsible for $\mathrm{N}_{2} \mathrm{O}$ consumption (Chapuis-Lardy et al., 2007) and that in those cases, the $\mathrm{N}_{2} \mathrm{O}$ is being reduced fully to $\mathrm{N}_{2}$. Since $\mathrm{NO}_{3}{ }^{-}$is a preferred electron acceptor over $\mathrm{N}_{2} \mathrm{O}$ and $n o s Z$ is sensitive to oxygen, it is likely that $\mathrm{N}_{2} \mathrm{O}$ uptake is confined to N-limited systems with low DO (Chapuis-Lardy et al., 2007). However, the two $\mathrm{N}_{2} \mathrm{O}$ uptake events in this study did not coincide with excessively low $\mathrm{NO}_{3}{ }^{-}$or DO levels in the wastewater. Therefore, circumstances resulting in $\mathrm{N}_{2} \mathrm{O}$ uptake are unclear.

We used the total surface area and estimates of the number of individuals served by each system to calculate normalized $\mathrm{N}_{2} \mathrm{O}$ emission values, which ranged from 0 to $624 \mathrm{mg} \mathrm{N}_{2} \mathrm{O}$ capita $^{-1} \mathrm{~d}^{-1}$ (Figure 2). The average for the WWTP was $6.0 \mathrm{mg}$ $\mathrm{N}_{2} \mathrm{O}$ capita ${ }^{-1} \mathrm{~d}^{-1}$, at the lower end of the range (0.8 to $383.6 \mathrm{mg} \mathrm{N}_{2} \mathrm{O}$ capita $\left.^{-1} \mathrm{~d}^{-1}\right)$ reported for other types of BNR systems at WWTPs (Ahn et al., 2010). The average $\mathrm{N}_{2} \mathrm{O}$ emission from OWTS in this study $\left(60 \mathrm{mg} \mathrm{N}_{2} \mathrm{O}\right.$ capita $\left.{ }^{-1} \mathrm{~d}^{-1}\right)$ is the first to our knowledge to be reported for any advanced OWTS and is higher than that determined from one conventional OWTS (without BNR) ( $5 \mathrm{mg} \mathrm{N}_{2} \mathrm{O}$ capita ${ }^{-1} \mathrm{~d}^{-1}$ ) (Diaz-Valbuena et al., 2011). Another study measured $\mathrm{N}_{2} \mathrm{O}$ emissions from the roof vent $(0.013 \mathrm{t}$ $\mathrm{CO}_{2}$ e capita $\left.{ }^{-1} \mathrm{yr}^{-1}\right)$, sand filter $\left(6.5 \times 10^{-4} \mathrm{t} \mathrm{CO}_{2} \mathrm{e}\right.$ capita $\left.{ }^{-1} \mathrm{yr}^{-1}\right)$, and leach field $\left(2.4 \times 10^{-}\right.$ ${ }^{3} \mathrm{t} \mathrm{CO}_{2} \mathrm{e}$ capita $^{-1} \mathrm{yr}^{-1}$ ) of several OWTS in New York (Truhlar et al., 2016). The $\mathrm{N}_{2} \mathrm{O}$ emissions measured in this study (Advantex: $0.08 \mathrm{t} \mathrm{CO}_{2} \mathrm{e}$ capita ${ }^{-1} \mathrm{yr}^{-1}$, SeptiTech $7.7 \mathrm{x}$ $10^{-3} \mathrm{t} \mathrm{CO}_{2} \mathrm{e}$ capita ${ }^{-1} \mathrm{yr}^{-1}$, and FAST $1.6 \times 10^{-3}$ ) were generally larger than those 
reported by Truhlar et al. (2016). Our results suggest that advanced OWTS designed for $\mathrm{N}$ removal may have higher $\mathrm{N}_{2} \mathrm{O}$ emissions than conventional advanced OWTS lacking $\mathrm{N}$ removal. The benefits of $\mathrm{N}$ removal at both WWTPs and OWTS may therefore come at the cost of increasing $\mathrm{N}_{2} \mathrm{O}$ in the atmosphere, which would transfer the $\mathrm{N}$ problem from one environment (wastewater) to another (the atmosphere). As more advanced OWTS are installed and/or WWTPs are upgraded to include BNR, they may become a significant source of $\mathrm{N}_{2} \mathrm{O}$.

\section{Nucleic Acid Concentration}

The concentration of nucleic acids (a proxy for the size of the microbial community) in all zones at the WWTP was five times higher than those of the three OWTS (Figure 3). This is interesting because it does not appear that the WWTP receives larger carbon inputs compared to OWTS. Although the BOD of the influent to the OWTS in this study was not measured, it typically ranges from 145 to $386 \mathrm{mg} / \mathrm{L}$ (Soil Science Society of America, 2014), which is similar to the average BOD of the WWTP influent in this study (200 mg/L) (Supplementary Table S2). The nucleic acid concentration was generally higher in SP1 (denitrification compartment) compared to SP2 (nitrification compartment) in all three of the OWTS (Figure 3). This is not surprising because SP1 of OWTS receive septic tank effluent with high BOD (Supplementary Table S2). 
Nitrifier (amoA) and denitrifier (nosZ) specific abundance

In general, amoA specific abundance was higher at the WWTP than any of the three OWTS technologies, except SP1 of FAST and SP2 of Advantex (Figure 1B). At the WWTP, the lowest amoA abundance was in the pre-anoxic zone, while the abundance in the other three zones (aerated IFAS, post-anoxic, and re-aeration) was similar in magnitude (Figure 1B). Out of the three OWTS, the highest amoA abundance was in FAST systems (Figure 1B). In addition, there was a trend of higher amoA abundance in the SP2 than SP1 in Advantex and SeptiTech systems but not FAST systems (Figure 1B). There was a significant positive relationship between amoA abundance and DO in denitrification zones/compartments $\left(\mathrm{p}<0.01, \mathrm{r}^{2}=0.88\right)$. The specific abundance of $a m o A$ in this study, 0 to $10^{2}$ copies/ng DNA, was within the range reported from other BNR systems $\left(10^{1}\right.$ to $10^{5}$ copies/ng DNA) including an integrated anoxic/oxic reactor (Wang et al., 2014) and conventional activated sludge (Song et al., 2014).

The specific abundance of nos $Z$ did not follow the same trends within and between system types as amoA abundance (Figure 1). The specific abundance of nosZ was generally higher in all three OWTS than in all four zones of the WWTP (Figure 1C). At the WWTP, there was higher nos $Z$ abundance in the aerated zones (aerated IFAS and re-aeration) compared to the anoxic zones (Figure 1C). This was surprising, since we expected that the higher DO concentrations of the aerated zones would result in lower nos $Z$ abundance, as it is part of an anaerobic pathway. However, it is possible that the high DO levels were maintaining a supply of oxidized $\mathrm{N}\left(\right.$ as $\mathrm{NO}_{3}{ }^{-}$) that supported the growth of denitrifiers (many of which contain nosZ). Another study 
of BNR systems at WWTPs found a similar trend of higher nos $Z$ abundance in aerobic zones compared to anoxic zones (Wang et al., 2014). Further, in our study there was a significant, albeit weak, positive relationship between nos $Z$ abundance and nitrate in the nitrification zones/compartments $\left(\mathrm{p}<0.01, \mathrm{r}^{2}=0.31\right)$. Some microorganisms can reduce nitrate even in the presence of relatively high DO concentrations (Robertson and Kuenen, 1984; Zhang et al., 2016). Although we do not know if the microorganisms in this study were actively reducing $\mathrm{N}_{2} \mathrm{O}$, we do know that they had the genetic capacity to do so and were relatively abundant in the aerated zones.

The abundance of nos $Z$ was similar among the three OWTS (Figure 1C), which suggests it did not play a strong role in accounting for notable differences in $\mathrm{N}_{2} \mathrm{O}$ emissions from the systems (Figure 1). As expected, there was a trend of higher nosZ abundance in SP1 than SP2 for FAST and SeptiTech systems (Figure 1C). The specific abundance of nos $Z$ ranged from 0 to $10^{3}$ copies/ng DNA, and was larger and more variable than that of $a m o A$, but was lower than reported from other types of BNR systems at WWTPs $\left(10^{4}-10^{5}\right.$ copies/ng DNA) (Song et al., 2014; Wang et al., 2014).

The ratio of amoA to nos $Z$ was higher in all zones of the WWTP than all three OWTS technologies (Figure 4). In some instances the amoA/nos $Z$ ratio at the WWTP was above one, indicating that there was a higher abundance of amoA than nosZ (Figure 4). In contrast, the amoA/nosZ ratio for OWTS was only above one once (Figure 4). The higher amoA/nosZ ratio at the WWTP seems to be related to the high $\mathrm{N}_{2} \mathrm{O}$ emissions observed there. However, there was not a significant relationship between $\mathrm{N}_{2} \mathrm{O}$ emissions and amoA/nos $\mathrm{Z}$ ratio among either the nitrification or 
denitrification zones/compartments of all systems (data not shown). The strongest relationship of amoA/nosZ was with $\mathrm{BOD}$ in nitrification zones/compartments $(\mathrm{p}=$ $\left.0.01, r^{2}=0.43\right)$.

\section{Relationships between gene abundance and $\mathrm{N}_{2} \mathrm{O}$ Emissions}

In our study, there was no significant relationship between $\mathrm{N}_{2} \mathrm{O}$ emissions and amoA or nos $Z$ abundance or wastewater properties for nitrification or denitrification zones/compartments (data not shown). This indicates that neither nitrification ( $a m o A)$ nor denitrification (nosZ) are solely responsible for the $\mathrm{N}_{2} \mathrm{O}$ emissions. The lack of statistically significant relationships was not particularly surprising. First, gene abundance indicates population size of specific microbial groups but not gene expression. For example, other studies have found that although abundance of DNA (amoA and nosZ) did not differ between BNR trains at a WWTP, mRNA gene expression did (Song et al., 2014). Further, they found a strong negative relationship between nos $\mathrm{Z}$ expression and $\mathrm{N}_{2} \mathrm{O}$ emissions (Song et al., 2014). Secondly, we collected water samples from a single depth. The abundance and activity of nitrifiers and denitrifiers likely varies with depth as a function of DO concentration. In addition, the production mechanism of $\mathrm{N}_{2} \mathrm{O}$ emissions may be more complicated than simple production by autotrophic nitrification or heterotrophic denitrification. For instance, nitrifier denitrification, the reduction of $\mathrm{NO}_{2}{ }^{-}$to $\mathrm{N}_{2} \mathrm{O}$ and $\mathrm{N}_{2}$ by nitrifiers, is another potential source of $\mathrm{N}_{2} \mathrm{O}$ (Wrage et al., 2001). Although there were no linear significant relationships between $\mathrm{N}_{2} \mathrm{O}$ emissions and amoA and nos $\mathrm{Z}$ abundance, there were interesting trends. Generally, the centralized WWTP had larger microbial 
populations (indicated by nucleic acid concentrations), lower nosZ abundance and therefore higher amoA/nosZ ratios compared to OWTS. This indicates that the higher $\mathrm{N}_{2} \mathrm{O}$ emissions at the WWTP (compared to OWTS) may be due to a larger nitrifying population $\left(\mathrm{N}_{2} \mathrm{O}\right.$ source $)$ and smaller complete denitrifying population $\left(\mathrm{N}_{2} \mathrm{O}\right.$ sink).

\section{Conclusion}

This preliminary evaluation of $\mathrm{N}_{2} \mathrm{O}$ emissions from three advanced OWTS technologies indicates that they are generally lower (on a mole/area basis) relative to an IFAS BNR system at a centralized WWTP. However, when the $\mathrm{N}_{2} \mathrm{O}$ emissions were normalized per population served and area of treatment tanks, they were similar between the WWTP and OWTS. Among the three technologies of advanced OWTS that were evaluated, the one with the highest $\mathrm{N}_{2} \mathrm{O}$ emissions was the Advantex system. Overall, the BNR systems examined in this study do not produce large $\mathrm{N}_{2} \mathrm{O}$ emissions relative to the amount of $\mathrm{N}$ removed, mostly $<1 \%$. The WWTP had higher amoA abundance and lower nos $\mathrm{Z}$ abundance compared to the OWTS. However, $\mathrm{N}_{2} \mathrm{O}$ emissions were not directly related to amoA nor nos $Z$ abundance or to the wastewater properties we evaluated.

Further evaluation of $\mathrm{N}_{2} \mathrm{O}$ emissions from emerging BNR technologies and their microbial sources should be conducted, particularly as they become increasingly numerous as wastewater treatment demands increase. 

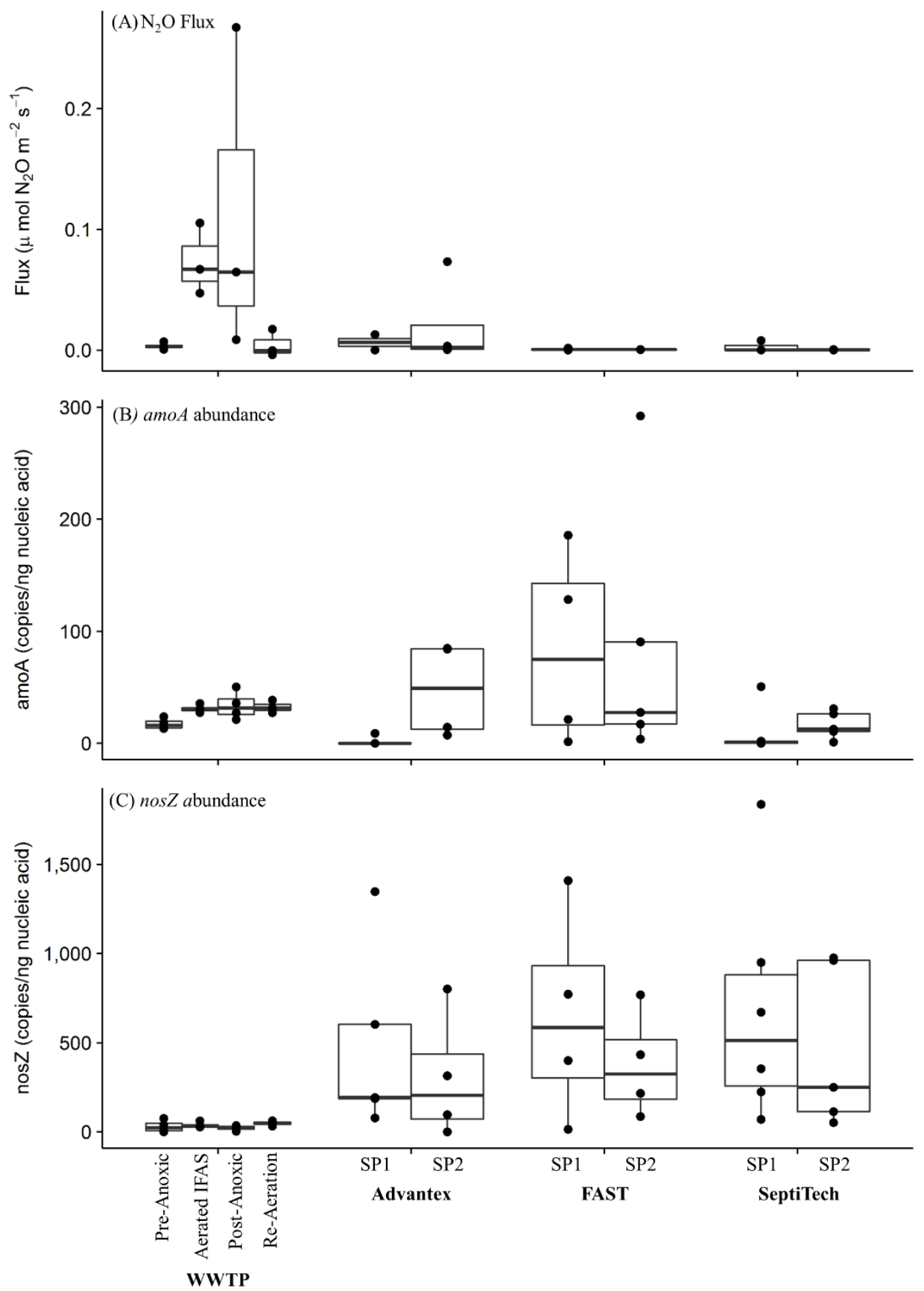

Figure 1. Nitrous oxide $\left(\mathrm{N}_{2} \mathrm{O}\right)$ fluxes (A), amoA abundance (B), and nos $Z$ abundance (C) from pre-anoxic, aerated IFAS, post-anoxic, and re-aeration zones in the wastewater treatment plant (WWTP) and denitrification (SP1) and nitrification (SP2) compartments in Advantex, FAST, and SeptiTech (onsite wastewater treatment systems). Solid line in middle of box represents the median, edge of box represents $1^{\text {st }}$ and $3^{\text {rd }}$ quartile, and whiskers extend $1.5 \mathrm{x}$ the inter quartile range beyond the edge of the box. 


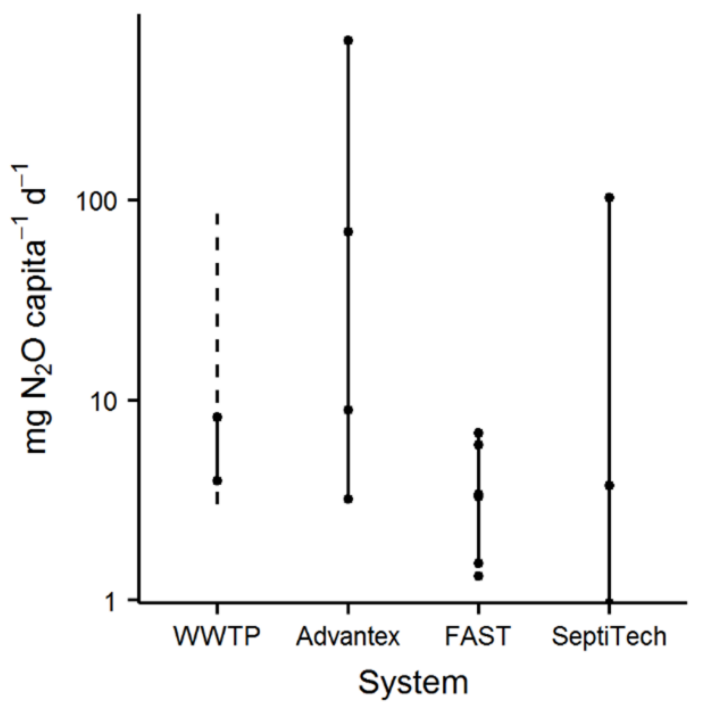

Figure 2. Range of $\mathrm{N}_{2} \mathrm{O}$ emissions $\left(\mathrm{mg} \mathrm{N}_{2} \mathrm{O}\right.$ capita $\left.{ }^{-1} \mathrm{~d}^{-1}\right)$ for each system as a whole (including all zones/compartments). Dashed line represents previously reported fluxes for WWTP examined in this study. For the WWTP there is a data point for each day of measurements $(n=2)$. For the OWTS, there is a data point for each house on each date that had significant emissions, Advantex $(n=4)$, SeptiTech $(n=4)$, and FAST $(n=6)$. 


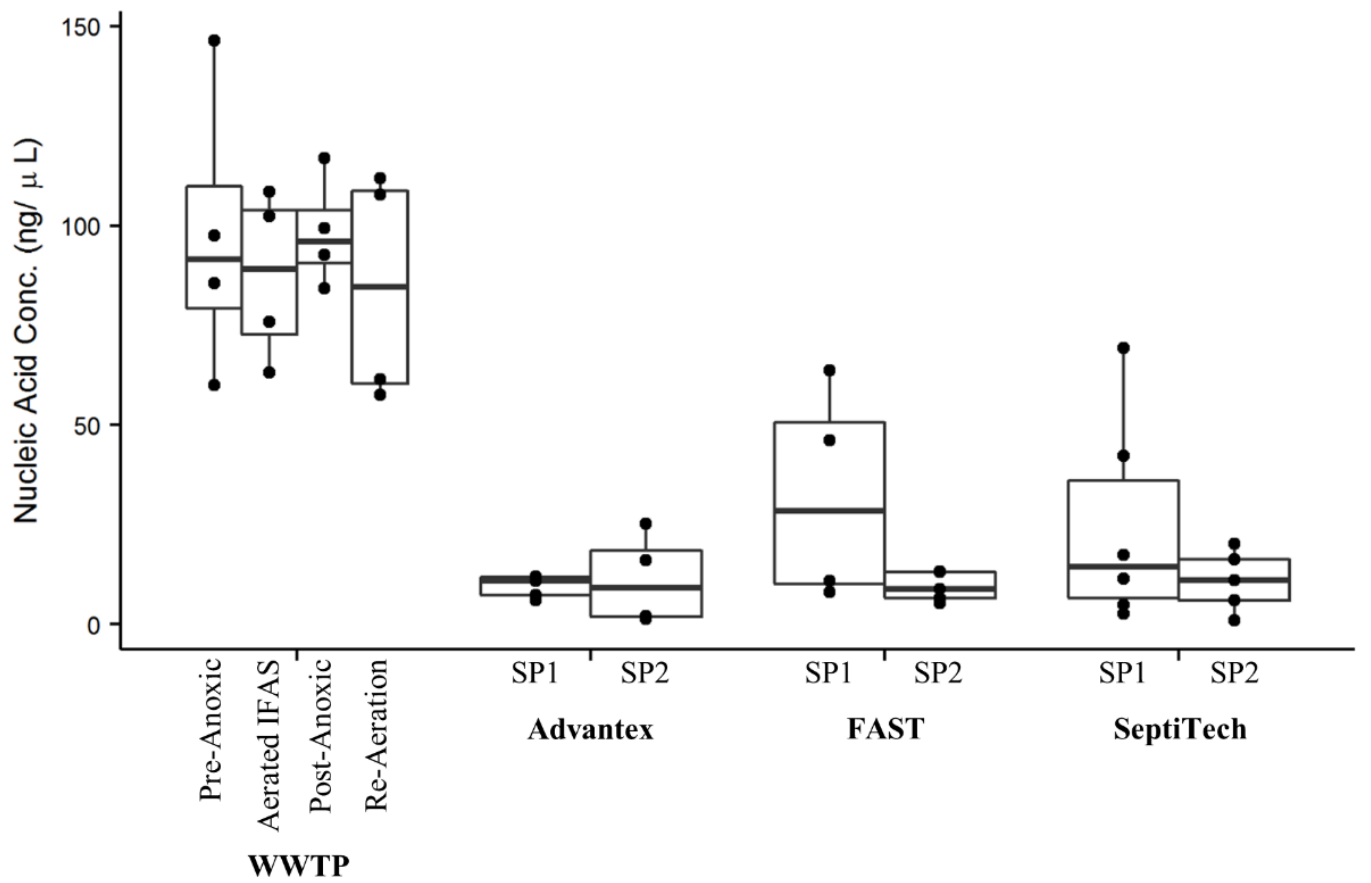

Figure 3. Nucleic acid concentration from pre-anoxic, aerated IFAS, post-anoxic, and re-aeration zones in the wastewater treatment plant (WWTP) and denitrification (SP1) and nitrification (SP2) compartments in Advantex, FAST, and SeptiTech (onsite wastewater treatment systems). Solid line in middle of box represents the median, edge of box represents $1^{\text {st }}$ and $3^{\text {rd }}$ quartile, and whiskers extend $1.5 \mathrm{x}$ the inter quartile range beyond the edge of the box. 


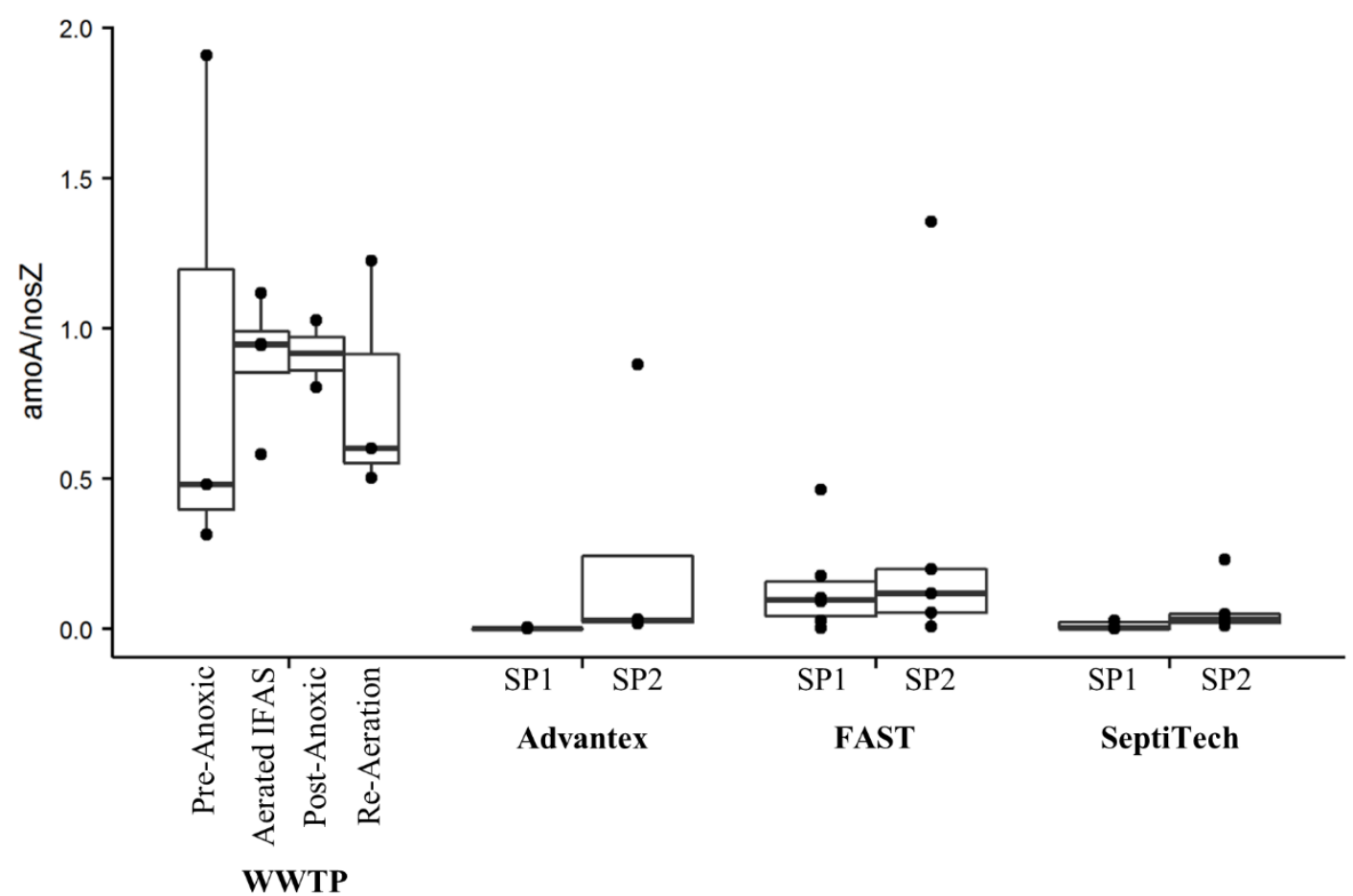

Figure 4. amoA/nosz ratio from pre-anoxic, aerated IFAS, post-anoxic, and re-aeration zones in the wastewater treatment plant (WWTP) and denitrification (SP1) and nitrification (SP2) compartments in Advantex, FAST, and SeptiTech (onsite wastewater treatment systems). Graph excludes one outlier (value $=16$ ) from post anoxic zone of WWTP. Solid line in middle of box represents the median, edge of box represents $1^{\text {st }}$ and $3^{\text {rd }}$ quartile, and whiskers extend $1.5 \mathrm{x}$ the inter quartile range beyond the edge of the box. 


\section{Supplementary}

\section{Equations:}

(1) Normalized WWTP Emission $\left(\mathrm{mg} \mathrm{N}_{2} \mathrm{O}_{\left.\text {capita }^{-1} \mathrm{~d}^{-1}\right)}=\frac{\sum_{i}^{n} \text { Flux }_{i}^{*} \text { Area }_{i}}{\text { Capita }_{\text {WWTP }}}\right.$ Where

Flux $_{\mathrm{i}}=$ Average of two $\mathrm{N}_{2} \mathrm{O}$ emissions calculated from the $i$ th zone $\left(\mathrm{mg} \mathrm{N}_{2} \mathrm{O} \mathrm{m} \mathrm{m}^{-2} \mathrm{~d}^{-1}\right)$

Area $=$ Area of zone scaled up for all 10 tanks $\left(\mathrm{m}^{2}\right)$

CapitawwTP $=$ Population served by WWTP: 226,000

(2) Normalized WWTP Emission $\left(\mathrm{mg} \mathrm{N}_{2} \mathrm{O}_{\text {capita }^{-1}} \mathrm{~d}^{-1}\right)=\frac{\text { Flux*Area }}{\text { Capita }_{\text {OWTS }}}$

Where

Flux $=$ Average of $\mathrm{N}_{2} \mathrm{O}$ emissions calculated from two compartments $\left(\mathrm{mg} \mathrm{N}_{2} \mathrm{O}\right.$ $\mathrm{m}^{-2} \mathrm{~d}^{-1}$ ) of each house on each date. Some locations only had a significant emission measurement from one compartment.

Area $=$ Total combined area of two compartments for each system $\left(\mathrm{m}^{2}\right)$

$\mathrm{FAST}=5$

Septi $=10$

Advantex $=7.4$

CapitaowTs $=$ Average population served by each technology type:

$\mathrm{FAST}=3$

SeptiTech $=3$ 
Advantex $=3.3$

(3) WWTP Emission Factor $\left(\%\right.$ of $\mathrm{N}$ removed released as $\left.\mathrm{N}_{2} \mathrm{O}\right)=$

$$
\frac{\sum_{i}^{n} \text { Flux }_{i}^{*} \text { Area }_{i}}{N R_{W W T P}} * 100
$$

Where

Flux $_{\mathrm{i}}=$ Average of two $\mathrm{N}_{2} \mathrm{O}$ fluxes calculated from the

$$
\text { ith zone }\left(\mathrm{g} \mathrm{N}_{2} \mathrm{O}-\mathrm{N} \mathrm{m}^{-2} \mathrm{~d}^{-1}\right)
$$

Area $_{i}=$ Area of zone scaled up for all 10 tanks $\left(\mathrm{m}^{2}\right)$

$\mathrm{NR}_{W W T P}=\mathrm{N}$ removed $\left(\mathrm{g} \mathrm{N} \mathrm{d}^{-1}\right)=$

$$
\text { [Influent - Effluent] (g N/L)* Flow Rate }\left(\mathrm{L} \mathrm{d}^{-1}\right)
$$

(4) OWTS Emission Factor $\left(\%\right.$ of $\mathrm{N}$ removed released as $\left.\mathrm{N}_{2} \mathrm{O}\right)=\frac{\text { Flux } * \text { Area }}{N R_{\text {OWTS }}} * 100$ Where

Flux $=$ Average $\mathrm{N}_{2} \mathrm{O}$ fluxes from two compartments $\left(\mathrm{g} \mathrm{N}_{2} \mathrm{O}-\mathrm{N} \mathrm{m}^{-2} \mathrm{~d}^{-1}\right)$

Area $=$ Total combined area of two compartments for each system $\left(\mathrm{m}^{2}\right)$

FAST $=5 ;$ Septi $=10 ;$ Advantex $=7.4$

NRowTs $=\mathrm{N}$ removed $\left(\mathrm{g} \mathrm{N} \mathrm{d}^{-1}\right)=$

[Influent - Effluent] (g N/L)* Flow Rate $\left(\mathrm{L} \mathrm{d}^{-1}\right)$

The amount of influent and effluent $\mathrm{N}$ removed for OWTS could not directly be measured. Instead it was assumed that all systems removed 
$0.02 \mathrm{~g} \mathrm{~N} / \mathrm{L}$. This was based on the assumption that the systems receive $\sim 0.04 \mathrm{~g} \mathrm{~N} / \mathrm{L}$ and remove $\sim 50 \%$ of the N (Office of Water Resources, 2016). Flow rate was not measured in October and instead the flow rate from October 2015 was used.

\section{References}

Office of Water Resources. 2016. Rules Establishing Minimum Standards Relating to Location, Design, Construction and Maintenance of Onsite Wastewater Treatment Systems. 
Table S1. Primer sets used for qPCR analysis.

\begin{tabular}{llll}
\hline Target Gene & Primer & Nucleotide Sequence & Reference \\
\hline Ammonium monooxygenase & amoA-1F & GGG GTT TCT ACT GGT GGT & Geets et al. (2007) \\
$($ amoA $)$ & amoA-682R & GAA SGC NGA GAA GAA SGC & Junier et al. (2009) \\
& & & \\
Nitrous oxide reductase & nosZ-F & CGY TGT TCM TCG ACA GCC AG & Geets et al. (2007) \\
$($ nos $)$ & nosZ 1622R & CGS ACC TTS TTG CCS TYG CG & Geets et al. (2007) \\
\hline
\end{tabular}


Table S2. Average and standard error of wastewater properties from pre-anoxic, aerated IFAS, post-anoxic, and re-aeration zones in the wastewater treatment plant and denitrification (SP1) and nitrification (SP2) compartments in Advantex, FAST, and SeptiTech (onsite wastewater treatment systems).

\begin{tabular}{|c|c|c|c|c|c|c|c|c|}
\hline $\begin{array}{l}\text { System and } \\
\text { zone/compartment }\end{array}$ & $\begin{array}{c}\text { Water } \\
\text { Flow Rate } \\
\text { (MGD) }\end{array}$ & $\begin{array}{l}\text { Water } \\
\text { Temp. } \\
\left({ }^{\circ} \mathrm{C}\right)\end{array}$ & $\begin{array}{c}\mathrm{DO} \\
(\mathrm{mg} / \mathrm{L})\end{array}$ & $\mathrm{pH}$ & $\begin{array}{c}\text { Total } \\
\text { Inorganic N } \\
(\mathrm{mg} \mathrm{N} / \mathrm{L})\end{array}$ & $\begin{array}{l}\text { Ammonium } \\
(\mathrm{mg} \mathrm{N} / \mathrm{L})\end{array}$ & $\begin{array}{l}\text { Nitrate } \\
(\mathrm{mg} \mathrm{N} / \mathrm{L})\end{array}$ & $\mathrm{BOD}_{5}$ \\
\hline WWTP & 31.9 & & & & & & & $211 \pm 5.0$ \\
\hline Pre-Anoxic & & $--^{a}$ & $0.3 \pm 0.0^{b}$ & $6.7 \pm 0.0^{b}$ & $7.2 \pm 0.6$ & $4.8 \pm 0.6$ & $0.3 \pm 0.1$ & $-^{a}$ \\
\hline Aerated IFAS & & $20.3 \pm 0.8$ & $2.8 \pm 2.4^{\mathrm{b}}$ & $6.7 \pm 0.0^{b}$ & $3.3 \pm 0.3$ & $1.1 \pm 0.6$ & $2.0 \pm 0.6$ & $-{ }^{\mathrm{a}}$ \\
\hline Post Anoxic & & $-{ }^{\mathrm{a}}$ & $1.6 \pm 1.4^{\mathrm{b}}$ & $6.5 \pm 0.1^{b}$ & $2.1 \pm 1.6$ & $3.0 \pm 1.8$ & $0.2 \pm 0.1$ & $-{ }^{a}$ \\
\hline Re-Aeration & & $-{ }^{a}$ & $0.5 \pm 0.1^{b}$ & $6.6 \pm 0.0^{b}$ & $0.5 \pm 0.1$ & $0.0 \pm 0.0$ & $0.5 \pm 0.1$ & $--^{a}$ \\
\hline Advantex & $2.1 \times 10^{-4}$ & & & & & & & \\
\hline SP1 & & $19.9 \pm 0.2$ & $0.2 \pm 0.2$ & $6.4 \pm 0.1$ & $15.9 \pm 3.1$ & $14.6 \pm 3.0$ & $1.3 \pm 0.3$ & $94.4 \pm 76.9$ \\
\hline $\mathrm{SP} 2$ & & $18.6 \pm 0.4$ & $1.8 \pm 1.0$ & $6.4 \pm 0.1$ & $15.7 \pm 4.7$ & $9.1 \pm 4.4$ & $6.6 \pm 2.8$ & $16.9 \pm 12.2$ \\
\hline FAST & $9.4 \times 10^{-5}$ & & & & & & & \\
\hline SP1 & & $20.3 \pm 0.6$ & $5.1 \pm 1.3$ & $7.2 \pm 0.2$ & $19.7 \pm 9.2$ & $8.4 \pm 4.9$ & $15.0 \pm 8.4$ & $0.0 \pm 0.0$ \\
\hline $\mathrm{SP} 2$ & & $18.5 \pm 0.4$ & $2.3 \pm 0.9$ & $7.0 \pm 0.2$ & $11.4 \pm 2.1$ & $1.7 \pm 0.6$ & $8.4 \pm 1.8$ & $6.0 \pm 4.2$ \\
\hline SeptiTech & $1.2 \times 10^{-4}$ & & & & & & & \\
\hline SP1 & & $21.4 \pm 1.0$ & $0.1 \pm 0.1$ & $7.2 \pm 0.2$ & $15.0 \pm 5.0$ & $11.5 \pm 4.8$ & $3.5 \pm 0.7$ & $10.3 \pm 9.9$ \\
\hline $\mathrm{SP} 2$ & & $22.1 \pm 1.1$ & $4.7 \pm 1.4$ & $7.1 \pm 0.1$ & $9.2 \pm 1.9$ & $3.1 \pm 1.7$ & $6.0 \pm 1.9$ & $3.7 \pm 1.8$ \\
\hline
\end{tabular}

${ }^{\mathrm{a}}$ Not determined $\quad{ }^{\mathrm{b}}$ Data for June only 


\section{Acknowledgements}

This work was funded by the USDA National Institute of Food and Agriculture [Hatch Project 22986, 2011; and Hatch Multi-state Project NE-1545 1007770, 2015], the Rhode Island Science and Technology Advisory Council [05098, 2016], and the URI Coastal Fellows Program, which provided funding for two undergraduate assistants. The authors thank the following people for assistance in the field: Dave Aucoin, Gina Celeste, Ashley Hogan, Katelyn Szura, and Barry Wenskowicz. The authors also thank Caleb Martin, Ph.D. and Rose Martin, Ph.D. for providing the $\mathrm{R}$ scripts used for emissions analysis. We also thank the homeowners of the OWTS for allowing us to conduct research on their systems. 


\section{References}

Ahn, J.H., S. Kim, H. Park, B. Rahm, K. Pagilla, and K. Chandran. 2010. N 2 O Emissions from Activated Sludge Processes, 2008-2009: Results of a National Monitoring Survey in the United States. Environ. Sci. Technol. 44(12): 45054511.

Brannon, E.Q., S.M. Moseman-Valtierra, C.W. Rella, R.M. Martin, X. Chen, and J. Tang. 2016. Evaluation of laser-based spectrometers for greenhouse gas flux measurements in coastal marshes. Limnol. Oceanogr. Methods 14: 466-476.

Chapuis-Lardy, L., N. Wrage, A. Metay, J.-L. Chotte, and M. Bernoux. 2007. Soils, a sink for $\mathrm{N}_{2} \mathrm{O}$ ? A review. Glob. Change Biol. 13(1): 1-17.

Core Writing Team, R.K. Pachauri, and L.A. Meyer. 2014. Climate Change 2014: Synthesis Report. IPCC, Geneva, Switzerland.

Diaz-Valbuena, L.R., H.L. Leverenz, C.D. Cappa, G. Tchobanoglous, W.R. Horwath, and J.L. Darby. 2011. Methane, Carbon Dioxide, and Nitrous Oxide Emissions from Septic Tank Systems. Environ. Sci. Technol. 45(7): 2741-2747.

Galloway, J., J. Aber, J. Erisman, S. Seitzinger, R. Howarth, E. Cowling, and J. Cosby. 2003. The Nitrogen Cascade. BioScience 53(4): 341-356.

Geets, J., M. de Cooman, L. Wittebolle, K. Heylen, B. Vanparys, P. De Vos, W. Verstraete, and N. Boon. 2007. Real-time PCR assay for the simultaneous quantification of nitrifying and denitrifying bacteria in activated sludge. Appl. Microbiol. Biotechnol. 75(1): 211-221. 
Hach Company. 2015. Nitrate Dimethylphenol TNT Plus Method. Available at http://www.hach.com/asset-get.download-en.jsa?code=50576 (verified 28 February 2017).

Howarth, R., D. Anderson, J. Cloern, C. Elfring, C. Hopkinson, B. Lapointe, T. Malone, N. Marcus, K. McGlathery, A. Sharpley, and D. Walker. 2000. Nutrient Pollution of Coastal Rivers, Bays, and Seas. Issues Ecol. 7: 1-16.

JMP. 1989. SAS Institute Inc., Cary, NC.

Junier, P., O.-S. Kim, T. Junier, T.-S. Ahn, J.F. Imhoff, and K.-P. Witzel. 2009. Community analysis of betaproteobacterial ammonia-oxidizing bacteria using the amoCAB operon. Appl. Microbiol. Biotechnol. 83(1): 175-188.

Lancellotti, B.V. 2016. Performance evaluation of advanced nitrogen removal onsite wastewater treatment systems. Diss. Masters Theses Campus Access: 1-109.

Law, Y., L. Ye, Y. Pan, and Z. Yuan. 2012. Nitrous oxide emissions from wastewater treatment processes. Philos. Trans. R. Soc. B Biol. Sci. 367(1593): 1265-1277.

Mello, W.Z. de, R.P. Ribeiro, A.C. Brotto, D.C. Kligerman, A. de S. Piccoli, and J.L. Oliveira. 2013. Nitrous oxide emissions from an intermittent aeration activated sludge system of an urban wastewater treatment plant. Quím. Nova 36(1): 1620.

Narragansett Bay Commission. 2017. Narrabay - Field's Point. Available at https://www.narrabay.com/en/About\%20Us/Facilities/Fields\%20Point.aspx (verified 28 February 2017).

Robertson, L.A., and J.G. Kuenen. 1984. Aerobic denitrification: a controversy revived. Arch. Microbiol. 139(4): 351-354. 
Soil Science Society of America. 2014. Conference Proceedings: Innovation in SoilBased Onsite Wastewater Treatment. Available at https://www.soils.org/files/meetings/specialized/full-conferenceproceedings.pdf (verified 28 February 2017).

Solorzano, L. 1969. Determination of Ammonia in Natural Waters by the Phenolhypochlorite Method. Limnol. Oceanogr. 14(5): 799-801.

Song, K., T. Suenaga, A. Hamamoto, K. Satou, S. Riya, M. Hosomi, and A. Terada. 2014. Abundance, transcription levels and phylogeny of bacteria capable of nitrous oxide reduction in a municipal wastewater treatment plant. J. Biosci. Bioeng. 118(3): 289-297.

Todt, D., and P. Dörsch. 2015. Nitrous oxide emissions in a biofilm loaded with different mixtures of concentrated household wastewater. Int. J. Environ. Sci. Technol. 12(11): 3405-3416.

Tomaszek, J., and J. Czarnota. 2015. A review of current knowledge on N2O emissions from WWTPs. In Tomaszek, Koszelnik (eds.), Progress in Environmental Engineering. Taylor \& Francis Group, London.

Truhlar, A.M., B.G. Rahm, R.A. Brooks, S.A. Nadeau, E.T. Makarsky, and M.T. Walter. 2016. Greenhouse Gas Emissions from Septic Systems in New York State. J. Environ. Qual. 0(0): 0.

United States Environmental Protection Agency (US EPA). 2013. Decentralized Wastewater Management Program Highlights. Available at https://www.epa.gov/sites/production/files/201506/documents/scb_decent_ar_2013_final-508compliant.pdf. 
US EPA. 2015. National Summary of State Information. Water Quality Assessment and TMDL Information. Available at https://ofmpub.epa.gov/waters10/attains_nation_cy.control (verified 26 December 2016).

Wang, Z., X.-X. Zhang, X. Lu, B. Liu, Y. Li, C. Long, and A. Li. 2014. Abundance and Diversity of Bacterial Nitrifiers and Denitrifiers and Their Functional Genes in Tannery Wastewater Treatment Plants Revealed by High-Throughput Sequencing. PLoS ONE 9(11): e113603.

Wrage, N., G.L. Velthof, M.L. van Beusichem, and O. Oenema. 2001. Role of nitrifier denitrification in the production of nitrous oxide. Soil Biol. Biochem. 33(1213): 1723-1732.

Zhang, J., W. Jia, R. Wang, H.H. Ngo, W. Guo, H. Xie, and S. Liang. 2016. Microbial community characteristics during simultaneous nitrification-denitrification process: effect of COD/TP ratio. Environ. Sci. Pollut. Res. 23(3): 2557-2565.

Zhu, G., Y. Peng, B. Li, J. Guo, Q. Yang, and S. Wang. 2008. Biological Removal of Nitrogen from Wastewater. Rev. Environ. Contam. Toxicol. 192: 159-195. 


\title{
APPENDICES
}

\section{APPENDIX 1}

\author{
EXAMINATION OF HOURLY VARIATION IN GREENHOUSE GAS \\ EMISSIONS FROM RE-AERATION ZONE OF BIOLOGICAL NITROGEN \\ REMOVAL AT A CENTRALIZED WASTEWATER TREATMENT
}

Since the greenhouse gas emissions measured in Chapter 2 were only collected during the morning hours, additional measurements were made throughout the day in order to examine hourly variability of the emissions. These measurements were performed on five days during 2014 and 2015 and employed the same methods as those outlined in Chapter 2. Three measurements were collected every 1.5 hours from 9:30 am to $3: 30 \mathrm{pm}$ from the same location in the re-aeration zone.

In general, $\mathrm{CH}_{4}$ and $\mathrm{CO}_{2}$ fluxes did not vary with time (Figure 1). However, on three dates $\left(10 / 14 / 14,6 / 17 / 14\right.$, and 6/30/15), $\mathrm{N}_{2} \mathrm{O}$ fluxes increased throughout the day. On one date (10/14/14), $\mathrm{N}_{2} \mathrm{O}$ fluxes were 50 times greater in the afternoon than morning. The results of this additional study supplement the large variability of $\mathrm{N}_{2} \mathrm{O}$ emissions observed in Chapter 2 (over 3 orders of magnitude). This continues to highlight the need for a better understanding of the large variation observed in emissions, especially $\mathrm{N}_{2} \mathrm{O}$. 

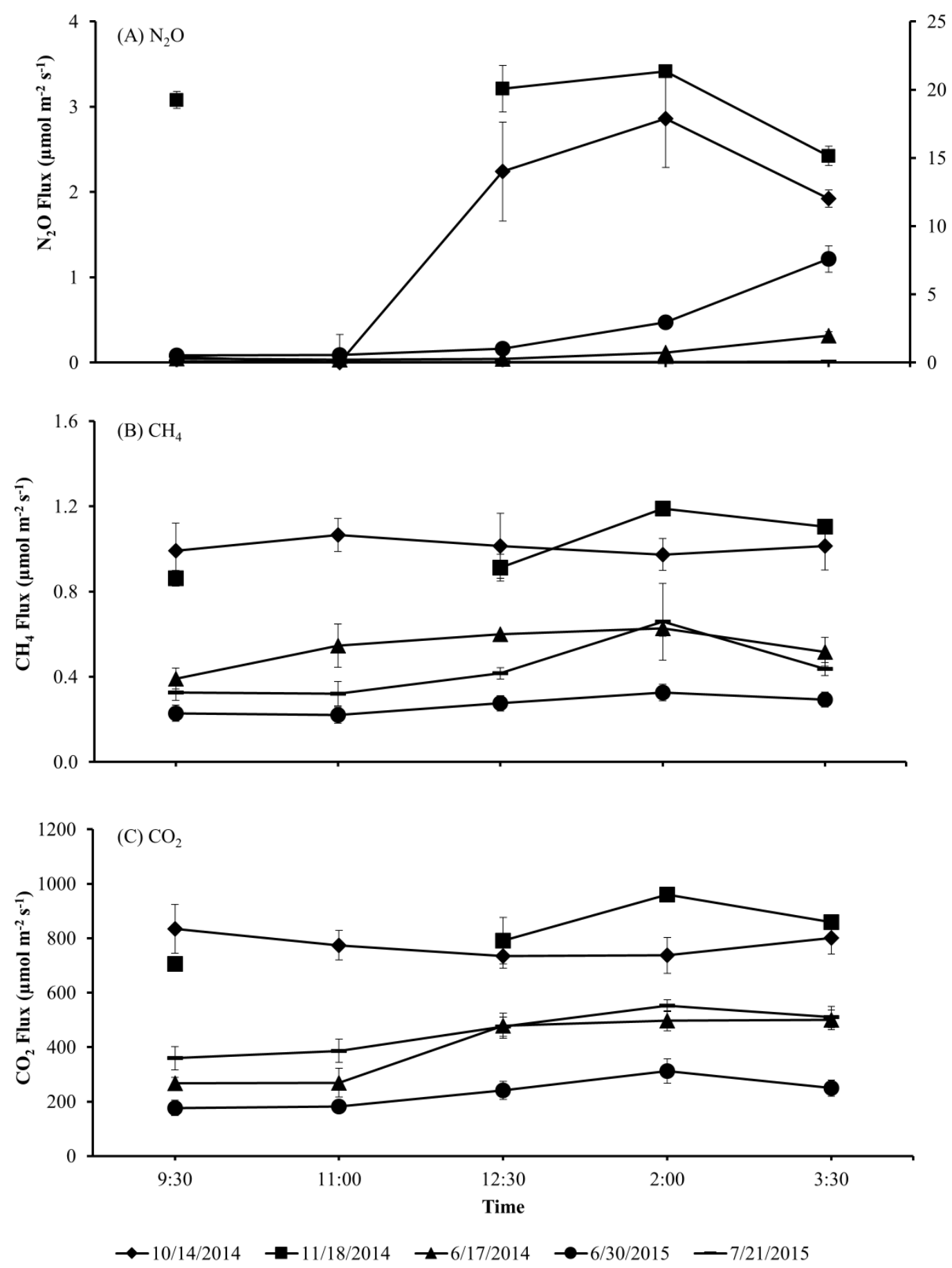

Figure 1. (A) $\mathrm{N}_{2} \mathrm{O}$, (B) $\mathrm{CH}_{4}$, and (C) $\mathrm{CO}_{2}$ fluxes from the re-aeration zone of the integrated fixed film activated sludge system at the Field's Point WWTP from 9:30 am to 3:30 pm on five different dates. The right axis for $\mathrm{N}_{2} \mathrm{O}$ is for the $11 / 18 / 14$ data. 


\section{APPENDIX 2}

\section{GREENHOUSE GAS EMISSIONS FROM ADDITIONAL COMPONENTS OF WASTEWATER TREATMENT PROCESS}

In order to determine the relative contribution of the biological nitrogen removal tanks (BNR) examined in Chapter 2 to the total greenhouse gas (GHG) emissions of the wastewater treatment plant (WWTP), on one date in September of 2016, GHG measurements were collected from components other than BNR at the Field's Point WWTP. Three flux measurements were collected using the same methods outlined in Chapter 2 from each of the following tanks: girt chamber, primary clarifier, and secondary clarifier (Figure 1). These fluxes were compared to the average and standard error of the yearlong fluxes presented in Chapter 2 from each zone and the BNR tank as a whole.

Measurable fluxes of all three gases $\left(\mathrm{N}_{2} \mathrm{O}, \mathrm{CO}_{2}\right.$, and $\left.\mathrm{CH}_{4}\right)$ were recorded from the grit chamber (Figure 2). However, only $\mathrm{CO}_{2}$ and $\mathrm{CH}_{4}$ fluxes were measured from the primary and secondary clarifiers (Figure 2). Out of the three additional components examined, the highest emissions of all three GHGs were from the grit chamber (Figure 2).

Fluxes of all three GHGs from the additional components (grit chamber, primary clarifier, and secondary clarifier) were lower than the average emissions from all zones of the BNR tank measured the previous year, except for $\mathrm{CH}_{4}$ fluxes from the 
grit chamber (Figure 2). Fluxes of $\mathrm{N}_{2} \mathrm{O}$ from the grit chamber were three orders of magnitude lower than the average from the BNR zone (aerated IFAS) with the highest $\mathrm{N}_{2} \mathrm{O}$ emissions and one order of magnitude lower than the average from the BNR zone (pre-anoxic) with the lowest $\mathrm{N}_{2} \mathrm{O}$ emissions (Figure $2 \mathrm{~A}$ ). Fluxes of $\mathrm{CO}_{2}$ from all three of the additional components were one and two orders of magnitude lower than the average $\mathrm{CO}_{2}$ fluxes from the re-aeration and aerated IFAS zones respectively of the BNR tank, but on the same order of magnitude as those from the pre-anoxic and postanoxic zones (Figure 2B). Fluxes of $\mathrm{CH}_{4}$ from the secondary clarifier were at least an order of magnitude lower than those from the BNR tank (Figure 2C). However, $\mathrm{CH}_{4}$ fluxes from the primary clarifier were on the same order of magnitude as those from the pre-anoxic and re-aeration zones of the BNR tank and fluxes from the grit chamber were on the same order of magnitude as those from the aerated IFAS zone (Figure 2C).

It was not surprising that out of the three additional components examined, the grit chamber had the largest emissions of all three GHGs (Figure 2). The grit chamber is aerated and mechanical stripping is likely leading to increased emissions. A study by Yan et al. (2014) found a similar trend of higher $\mathrm{N}_{2} \mathrm{O}, \mathrm{CH}_{4}$, and $\mathrm{CO}_{2}$ emissions from grit tanks compared to clarifiers. It is also not surprising that $\mathrm{CH}_{4}$ fluxes from the grit chamber were high. Wastewater entering the plant likely contains high concentrations of dissolved $\mathrm{CH}_{4}$ as anaerobic conditions have been documented in sewers (Guisasola et al., 2009). The grit chamber is the first component that contains aeration which likely results in the stripping of all the dissolved $\mathrm{CH}_{4}$ that has accumulated in the influent pipes. The fact that additional $\mathrm{CH}_{4}$ fluxes were observed 
in the aerated zones of the BNR tank suggests that either some dissolved $\mathrm{CH}_{4}$ was not stripped in the grit chamber or additional $\mathrm{CH}_{4}$ production occurred in the primary clarifiers (located after the grit chamber) and was stripped in the aerated zones of the BNR tanks. Future studies should include measurements of dissolved $\mathrm{CH}_{4}$ so that the location of $\mathrm{CH}_{4}$ production relative to emission can be determined. Low to no $\mathrm{N}_{2} \mathrm{O}$ emissions from the additional components was expected because the components are not designed to include nitrogen removal and therefore would not likely contain nitrifying and denitrifying organisms responsible for $\mathrm{N}_{2} \mathrm{O}$ production. Likewise, low $\mathrm{CO}_{2}$ emissions were expected because the components are not designed to contain large microbial populations.

In terms of $\mathrm{CO}_{2}$ equivalence (using global warming potential of 265 for $\mathrm{N}_{2} \mathrm{O}$ and 28 for $\mathrm{CH}_{4}$ ) and normalizing by tank surface area, the average total emissions (including $\mathrm{N}_{2} \mathrm{O}, \mathrm{CO}_{2}$, and $\mathrm{CH}_{4}$ ) from the grit chambers, primary clarifiers, and final clarifiers are 12,66 , and 32 tonne $\mathrm{CO}_{2}$ eq. $\mathrm{y}^{-1}$, respectively. This is compared to 6637 tonne $\mathrm{CO}_{2}$ eq. $\mathrm{y}^{-1}$ from all four zones and 10 tanks of BNR. It should be noted that measurements were only collected on one date from the grit chambers, primary clarifiers and final clarifiers. Additional studies are needed to determine the temporal variability of the emissions. However, the measured GHG emissions from the grit chamber, primary clarifier and secondary clarifier combined represented less than $0.5 \%$ of the WWTPs total GHG budget, while BNR represented 12\%. Therefore, future efforts to reduce emissions should focus on the BNR tanks. 


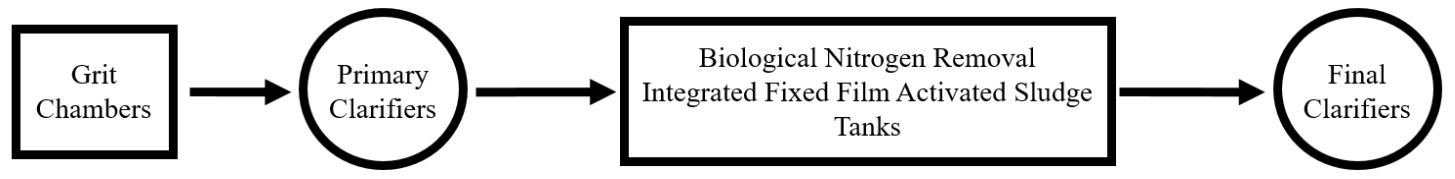

Figure 1. Simplified diagram of treatment train at Field's Point wastewater treatment plant. The figure shows only the components GHGs were measured from in this study. 

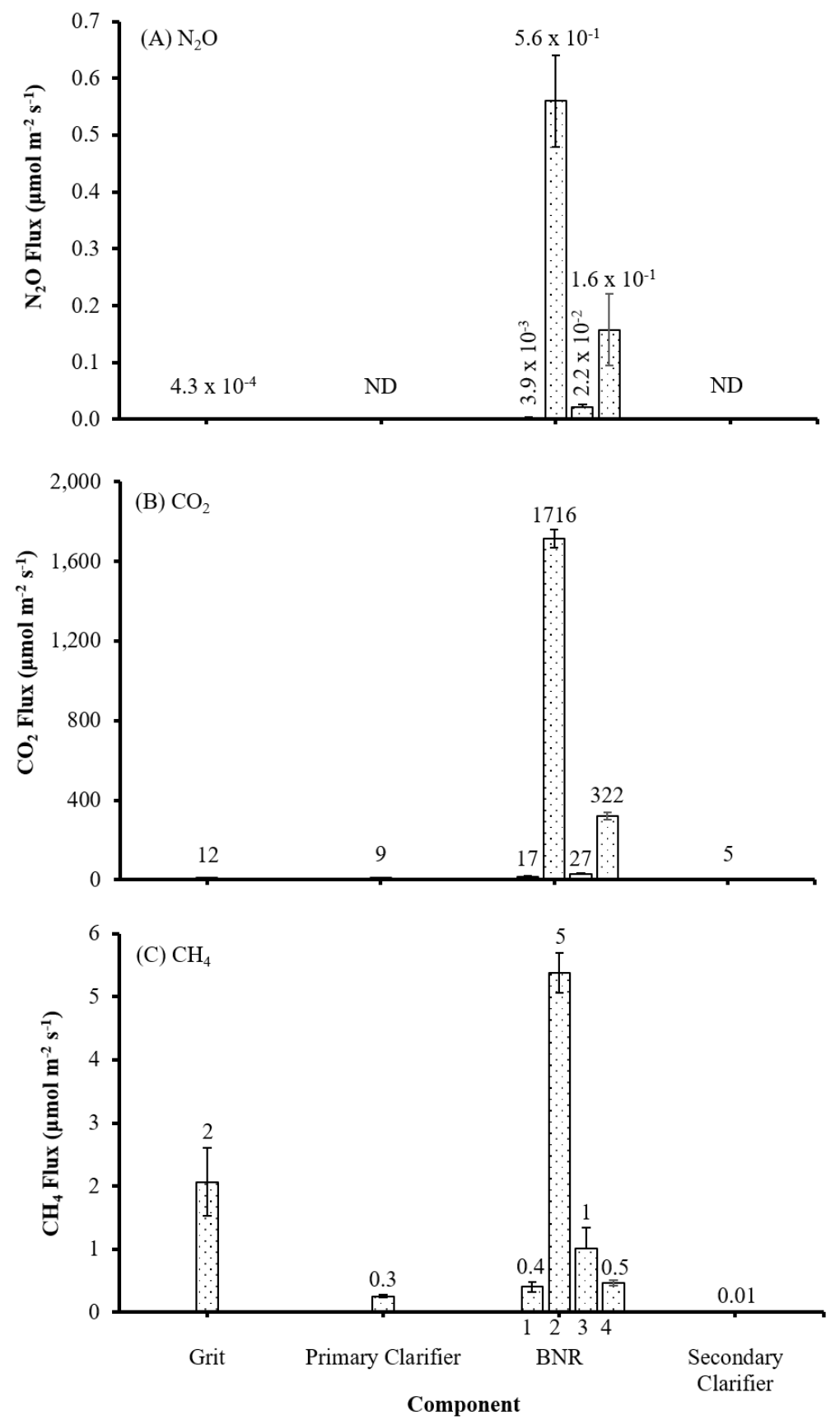

Figure 2. Average and standard error of three (A) $\mathrm{N}_{2} \mathrm{O}$, (B) $\mathrm{CO}_{2}$, and (C) $\mathrm{CH}_{4}$ flux measurements made in September 2016 from each additional component (grit chamber, primary clarifier, and secondary clarifier) at the Field's Point wastewater treatment plant. Average and standard error of flux measurements made from June 2014 - June 2015 (Chapter 2) from the (1) pre-anoxic, (2) aerated IFAS, (3) postanoxic, and (4) re-aeration zones of one integrated fixed film activated sludge biological nitrogen removal tank. Fluxes that were not significant are reported as not detectable (ND). 


\section{References}

Guisasola, A., K.R. Sharma, J. Keller, and Z. Yuan. 2009. Development of a model for assessing methane formation in rising main sewers. Water Res. 43(11): 28742884.

Yan, X., L. Li, and J. Liu. 2014. Characteristics of greenhouse gas emission in three full-scale wastewater treatment processes. J. Environ. Sci. 26(2): 256-263. 


\section{APPENDIX 3}

\section{INVESTIGATING THE USE OF $\mathrm{N}_{2} \mathrm{O}$ ISOTOPOMERS TO TEST MECHANISMS OF $\mathrm{N}_{2} \mathrm{O}$ PRODUCTION}

The results of Chapter 2 of this dissertation indicated that $\mathrm{N}_{2} \mathrm{O}$ fluxes from the integrated fixed film activated sludge (IFAS) biological nitrogen removal (BNR) system at the Field's Point wastewater treatment plant (WWTP) varied by over four orders of magnitude over the course of a year. As a result, a preliminary study was conducted in the summer of 2016 to investigate the ability of $\mathrm{N}_{2} \mathrm{O}$ isotopomers to provide insight to the mechanisms that may be responsible for this variation.

Nitrous oxide can be produced by several processes including, but not limited to, nitrification, denitrification, and nitrifier denitrification (Wrage et al., 2001). To complicate matters, denitrification can both consume and produce $\mathrm{N}_{2} \mathrm{O}$ (Wrage et al., 2001). Although several studies have attempted to determine the mechanism of $\mathrm{N}_{2} \mathrm{O}$ emissions from BNR processes, no consensus has been found (Gejlsbjerg et al., 1998; Schramm et al., 2000; Tallec et al., 2006; Wunderlin et al., 2012). A better understanding of the mechanism responsible for $\mathrm{N}_{2} \mathrm{O}$ emissions will help develop mitigation strategies.

Examination of isotopomers is one approach that can help determine the mechanisms responsible for $\mathrm{N}_{2} \mathrm{O}$ production. Isotopomers refers to the intramolecular distribution of ${ }^{15} \mathrm{~N}$ within the $\mathrm{N}_{2} \mathrm{O}$ molecule, also called site preference (Wunderlin et 
al., 2012). Previous studies have demonstrated differences in the site preference of $\mathrm{N}_{2} \mathrm{O}$ based on the mechanism responsible for production (Table 1) (Wunderlin et al., 2012). Negative site preference values are associated with denitrification and nitrifier denitrification and positive values are associated with nitrification (Wunderlin et al., 2012). Site preference in combination with $\Delta \delta^{15} \mathrm{~N}\left(\Delta \delta^{15} \mathrm{~N}=\delta^{15} \mathrm{~N}_{\text {substrate }}-\delta^{15} \mathrm{~N}^{\text {bulk }}{ }_{\mathrm{N} 2 \mathrm{O}}\right)$ can further discern between $\mathrm{N}_{2} \mathrm{O}$ produced by nitrifier denitrification and denitrification (Table 1) (Wunderlin et al., 2012).

On three dates (June, July, and August) in the summer of 2016, flux measurements were conducted as outlined in Chapter $2(\mathrm{n}=3$ per zone on each date). At the end of each flux measurement, before the chamber was removed from the water, a gas sample was drawn by hand from the inflow tubing into a $60 \mathrm{~mL}$ nylon syringe equipped with a Luer-Lok stopcock. Samples were stored at $4^{\circ} \mathrm{C}$ until a 10 $\mathrm{mL}$ subsample was analyzed on a Shimadzu Gas Chromatograph-2014 to confirm the concentration within 5 days of collection. Then, the remaining sample was transferred to a $12 \mathrm{~mL}$ pre-evacuated glass vial (Exetainers, Labco). The vials were stored in water and shipped to Picarro, Inc. for isotopomer analysis on a G5131-I (Picarro, Inc.). Samples were analyzed within approximately three months of collection. Standards ( $\mathrm{N}_{2} \mathrm{O}$ concentration: 0.5 and $2.1 \mathrm{ppm}$ ) were also transferred to vials and shipped to track gas loss.

The sampling method was valid based on the agreement in $\mathrm{N}_{2} \mathrm{O}$ concentrations between the Picarro used at the time of sample collection and GC (data not shown). However, due to the long storage period, substantial gas loss (50\%) was observed. As a result, a large proportion (67\%) of the samples were up to $160 \mathrm{ppb}$ below the 
measuring range of the analyzer. All the data is included in the analysis below but results should be evaluated with caution.

Although there does not appear to be a large difference in site preference between zones, there was a difference between dates (Figure 1). In June site preference was negative in all four zones, indicating that $\mathrm{N}_{2} \mathrm{O}$ emissions in June (generally low, average: $3.9 \times 10^{-2}$ ) were from either denitrification or nitrifier denitrification (Figure 1). Since, $\Delta \delta^{15} \mathrm{~N}$ was not measured in this study it is not possible to distinguish between denitrification and nitrifier denitrification. However, in July and August, when $\mathrm{N}_{2} \mathrm{O}$ emissions were generally higher (average: $5.6 \times 10^{-2}$ ), site preference was positive in all zones, indicating the nitrification was the source of $\mathrm{N}_{2} \mathrm{O}$ (Figure 1).

Despite the complications (long storage time resulting in substantial gas loss) mentioned above, the results indicate that site preference may be useful in understanding temporal differences in $\mathrm{N}_{2} \mathrm{O}$ fluxes. Therefore, future studies that include adjusted methodology are warranted and should include bulk $\Delta \delta^{15} \mathrm{~N}$ in order to differentiate the contribution of nitrifier denitrification and denitrification to $\mathrm{N}_{2} \mathrm{O}$ production. 
Table 1. Range of reported site preference (SP) and $\Delta \delta^{15} \mathrm{~N}$ for each potential source of $\mathrm{N}_{2} \mathrm{O}$ (Wunderlin et al. 2013).

\begin{tabular}{lcc} 
Process & SP $(\%$ o) & $\Delta \delta^{15} \mathrm{~N}(\%$ o) \\
\hline Nitrification $^{6}$ & 30.8 to 36.3 & 47 to 68 \\
Nitrifier Denitrification $^{6}$ & -10.7 to 0.1 & 47 to 68 \\
Denitrification $^{6}$ & -5 to 0 & 0 to 39 \\
\hline
\end{tabular}




\section{(A) Site Preference}
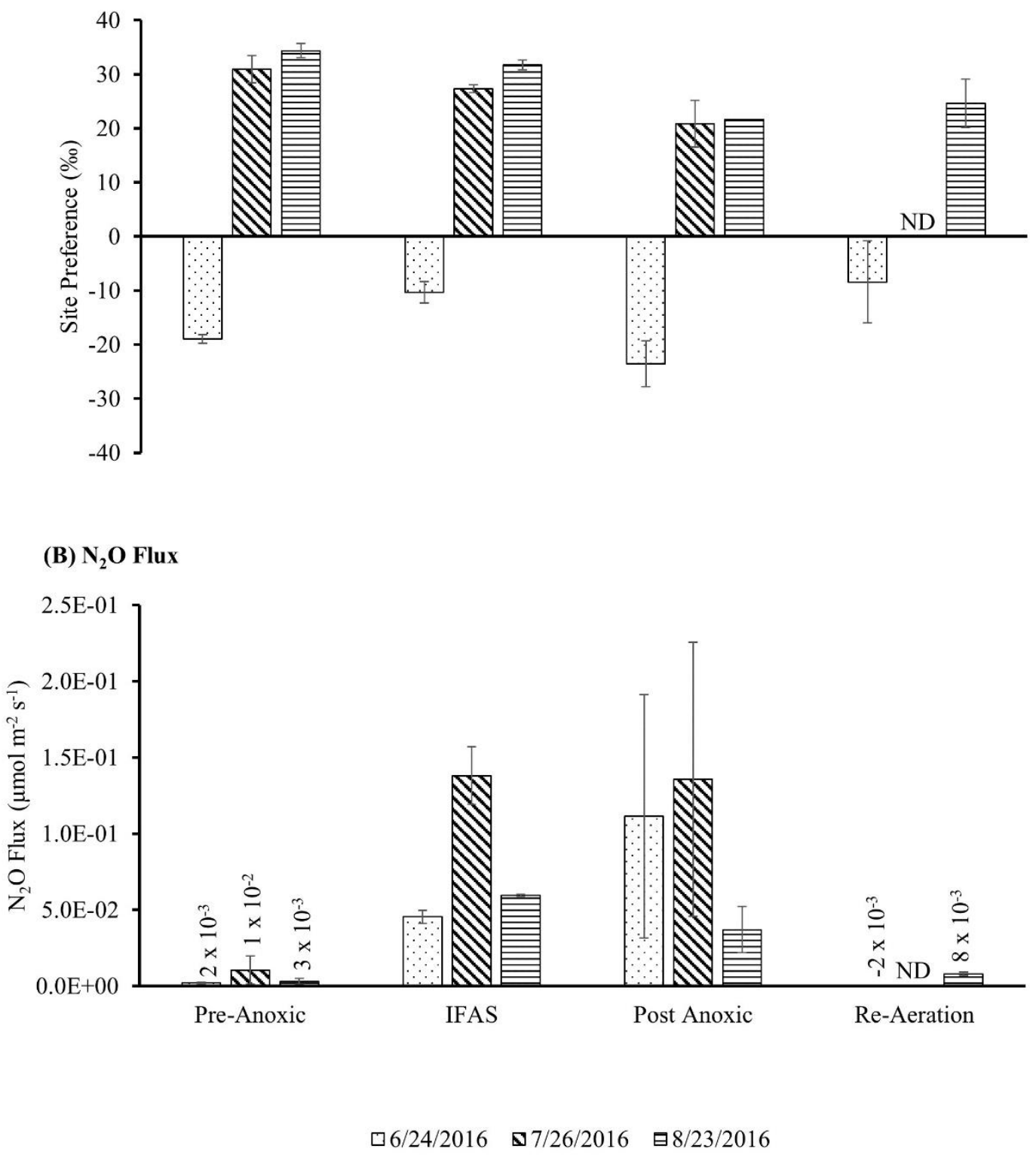

Figure 1. (A) Site preference and (B) $\mathrm{N}_{2} \mathrm{O}$ fluxes from each zone on each date. $\mathrm{ND}=$ no data collected. 


\section{References}

Gejlsbjerg, B., L. Frette, and P. Westermann. 1998. Dynamics of N2O production from activated sludge. Water Res. 32(7): 2113-2121.

Schramm, A., D. De Beer, A. Gieseke, and R. Amann. 2000. Microenvironments and distribution of nitrifying bacteria in a membrane-bound biofilm. Environ. Microbiol. 2(6): 680-686.

Tallec, G., J. Garnier, G. Billen, and M. Gousailles. 2006. Nitrous oxide emissions from secondary activated sludge in nitrifying conditions of urban wastewater treatment plants: Effect of oxygenation level. Water Res. 40(15): 2972-2980.

Wrage, N., G.L. Velthof, M.L. van Beusichem, and O. Oenema. 2001. Role of nitrifier denitrification in the production of nitrous oxide. Soil Biol. Biochem. 33(1213): 1723-1732.

Wunderlin, P., J. Mohn, A. Joss, L. Emmenegger, and H. Siegrist. 2012. Mechanisms of $\mathrm{N} 2 \mathrm{O}$ production in biological wastewater treatment under nitrifying and denitrifying conditions. Water Res. 46(4): 1027-1037. 


\section{APPENDIX 4}

\section{CARBON DIOXIDE AND METHANE EMISSIONS FROM BIOLOGICAL NITROGEN REMOVAL: A COMPARISON BETWEEN A CENTRALIZED WWTP AND ONISITE WASTEWATER TREATMENT SYSTEMS}

Carbon dioxide $\left(\mathrm{CO}_{2}\right)$ and methane $\left(\mathrm{CH}_{4}\right)$ fluxes were measured in conjunction with the nitrous oxide $\left(\mathrm{N}_{2} \mathrm{O}\right)$ flux measurements from biological nitrogen removal (BNR) systems at a centralized wastewater treatment plant (WWTP) and advanced onsite wastewater treatment systems (OWTS) outlined in Chapter 3 of this dissertation. The $\mathrm{CO}_{2}$ and $\mathrm{CH}_{4}$ measurements were not included in Chapter 3 as they did not have accompanying gene abundance data. Carbon dioxide and $\mathrm{CH}_{4}$ are potent greenhouse gases (GHGs) and when examined in conjunction with $\mathrm{N}_{2} \mathrm{O}$ emissions allow for a more complete understanding of the impact these systems have on climate change.

The $\mathrm{CO}_{2}$ and $\mathrm{CH}_{4}$ fluxes measurements were made on the same dates (June and October) and collected from the same locations as those outlined in Chapter 3. This was the first known study to directly compare all three GHG emissions between a WWTP and advanced OWTS designed to remove nitrogen. Although $\mathrm{CO}_{2}$ and $\mathrm{CH}_{4}$ emissions were observed from all systems, $\mathrm{CH}_{4}$ uptake was observed on one occasion (SP2 of FAST). In addition, several $\mathrm{CO}_{2}$ and $\mathrm{CH}_{4}$ fluxes were either zero or below the detection limit $(\mathrm{WWTP}=0$, Advantex $=0$, Septi $=1, \mathrm{FAST}=4)$. Four fluxes from two Advantex (3 from SP1 and 1 from SP2) systems were above the analyzer's 
detection limit for $\mathrm{CH}_{4}$. Since the analyzer measures all three gases simultaneously, $\mathrm{CO}_{2}$ flux measurements could not be made for those Advantex systems.

Emissions of $\mathrm{CO}_{2}$ at the WWTP were an order of magnitude higher from the aerated zones (aerated IFAS and re-aeration) than the anoxic zones (pre-anoxic and post-anoxic) (Figure 1A). The WWTP $\mathrm{CO}_{2}$ fluxes represented 0.25 to $0.40 \mathrm{~kg} \mathrm{CO}_{2} / \mathrm{kg}$ influent chemical oxygen demand (COD). This is below the range (0.58 to $0.97 \mathrm{~kg}$ $\mathrm{CO}_{2} / \mathrm{kg} \mathrm{COD}$ ) reported by studies from other types of BNR systems at WWTPs (Bao et al., 2015). Similar to the $\mathrm{N}_{2} \mathrm{O}$ emissions, the $\mathrm{CO}_{2}$ emissions reported here $(0.25$ to $0.4 \mathrm{~kg} \mathrm{CO}_{2} / \mathrm{kg}$ influent COD) were on the lower end of the range for the yearlong measurements conducted in Chapter 2 of this dissertation $\left(0.2-1.1 \mathrm{~kg} \mathrm{CO}_{2} / \mathrm{kg}\right.$ influent COD).

The largest $\mathrm{CO}_{2}$ emissions from the OWTS were from the Advantex system (Figure 1A). The Advantex systems also had the highest biological oxygen demand (BOD) values. A higher BOD can result from increased activity of microorganism that respire $\mathrm{CO}_{2}$. There was a trend of higher $\mathrm{CO}_{2}$ emissions from SP1 than SP2 for all three OWTS systems (Figure 1A). This was not surprising as SP1 receives influent water that has high BOD.

When comparing $\mathrm{CO}_{2}$ emissions between the WWTP and OWTS, $\mathrm{CO}_{2}$ emissions from the aerated IFAS and re-aeration zones at the WWTP were higher than those from all three OWTS (Figure 1A). However, $\mathrm{CO}_{2}$ emissions from the preanoxic and post-anoxic zones were similar in magnitude to those from SP1 of Advantex systems (Figure 1A). All other OWTS had $\mathrm{CO}_{2}$ emissions below those at the WWTP (Figure 1A). 
Methane emissions at the WWTP were highest from the aerated IFAS and post-anoxic zones (Figure 1B). The $\mathrm{CH}_{4}$ emissions from the WWTP represented 0.05 to $0.09 \% \mathrm{~kg} \mathrm{CO}_{2} / \mathrm{kg} \mathrm{COD}$. This is at the lower end of the range $(0.07$ to $1.13 \% \mathrm{~kg}$ $\mathrm{CH}_{4} / \mathrm{kg} \mathrm{COD}$ ) reported by studies from other types of BNR systems at WWTPs (Aboobakar et al., 2014). Similar to the $\mathrm{N}_{2} \mathrm{O}$ and $\mathrm{CO}_{2}$ emissions, the $\mathrm{CH}_{4}$ emissions reported here ( 0.05 to $0.09 \mathrm{~kg} \mathrm{CO} / \mathrm{kg} \mathrm{COD}$ ) were on the lower end of the range for the yearlong measurements conducted in Chapter 2 of this dissertation (0.02 to $0.13 \%$ $\mathrm{kg} \mathrm{CH}_{4} / \mathrm{kg}$ influent COD).

The largest $\mathrm{CH}_{4}$ emissions from the OWTS were from Advantex SP1 (Figure 1B). This was also the system that had $\mathrm{CH}_{4}$ emissions above the measuring range of the analyzer on four occasions. The Advantex SP1 also had the lowest dissolved oxygen (DO) out of all the systems which might explain the higher $\mathrm{CH}_{4}$ emissions. Other studies have found a weak correlation between $\mathrm{CH}_{4}$ emissions and DO in other BNR systems (Wang et al., 2011; Aboobakar et al., 2014). There was a trend of higher $\mathrm{CH}_{4}$ emissions from SP1 than SP2 for all three OWTS systems (Figure 1B). This was not surprising as the SP1 compartment is designed to have lower DO than SP2.

When comparing $\mathrm{CH}_{4}$ emissions between the WWTP and OWTS, $\mathrm{CH}_{4}$ emissions were highest from the Advantex SP1 system followed by the aerated IFAS and post-anoxic zones at the WWTP and SeptiTech SP1 (Figure 1B). All other systems had similar $\mathrm{CH}_{4}$ emissions (pre-anoxic and re-aeration at WWTP, SP2 Advantex, SP1 and SP2 of FAST and SP2 of SeptiTech). 
When considering both the $\mathrm{CH}_{4}$ and $\mathrm{CO}_{2}$ emissions presented here along with the $\mathrm{N}_{2} \mathrm{O}$ fluxes presented in Chapter 3,93\% of the emissions from all three GHGs at the WWTP were from $\mathrm{CO}_{2}$, compared to only $29 \%$ at OWTS. In OWTS, $\mathrm{CH}_{4}$ emissions were largest, representing $62 \%$ of the total emissions from all three GHGs. As more advanced OWTS are installed, these systems have the potential to become significant sources of $\mathrm{CH}_{4}$. However, this is a limited dataset and additional measurements, especially at OWTS, will be needed in order to examine spatial and temporal variability in the emissions. 


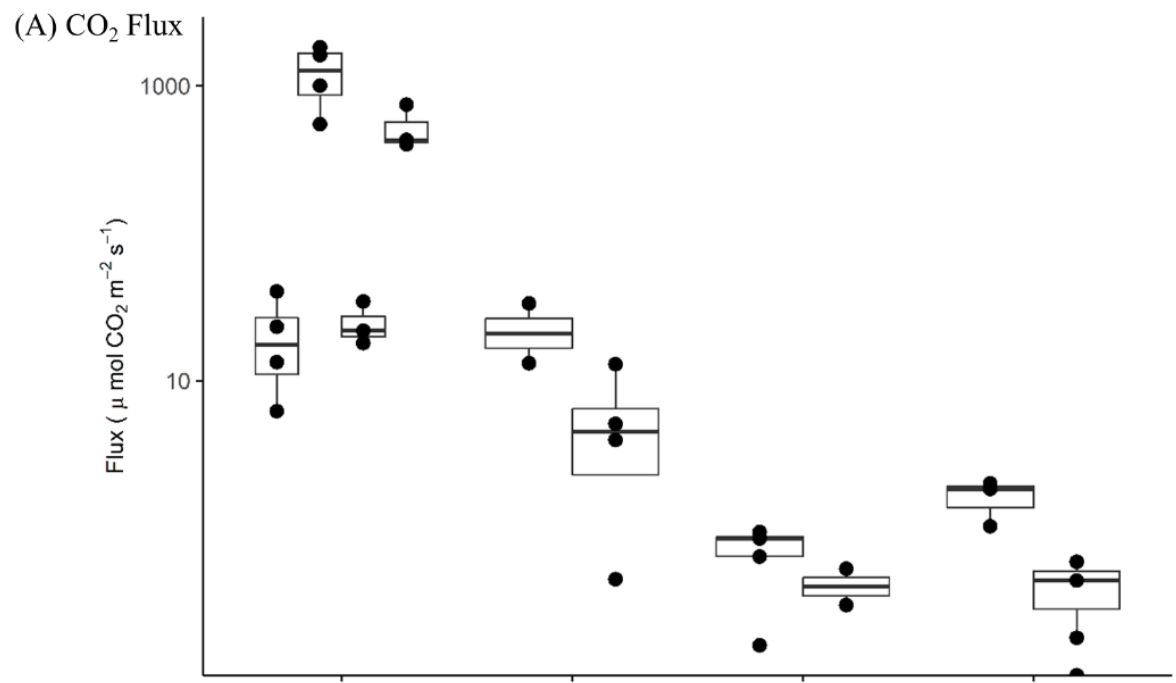

(B) $\mathrm{CH}_{4}$ Flux

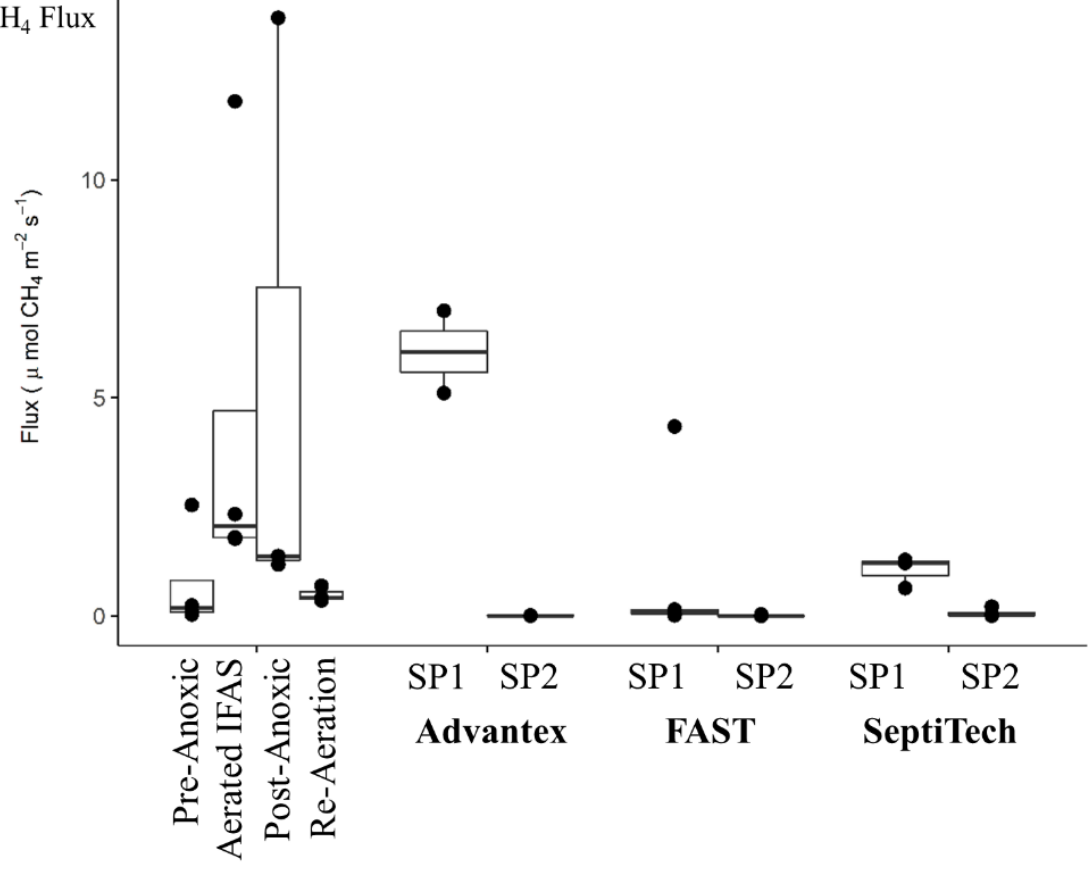

WWTP

Figure 1. (A) Carbon Dioxide $\left(\mathrm{CO}_{2}\right)$ and methane $\left(\mathrm{CH}_{4}\right)$ from pre-anoxic, aerated IFAS, post-anoxic, and re-aeration zones in the wastewater treatment plant (WWTP) and nitrification (SP1) and denitrification (SP2) compartments in Advantex, FAST, and SeptiTech (onsite wastewater treatment systems). Solid line in middle of box represents the median, edge of box represents $1^{\text {st }}$ and $3^{\text {rd }}$ quartile, and whiskers extend $1.5 \mathrm{x}$ the inter quartile range beyond the edge of the box. 


\section{References}

Aboobakar, A., M. Jones, P. Vale, E. Cartmell, and G. Dotro. 2014. Methane Emissions from Aerated Zones in a Full-Scale Nitrifying Activated Sludge Treatment Plant. Water. Air. Soil Pollut. 225(1)Available at http://link.springer.com/10.1007/s11270-013-1814-8 (verified 17 May 2014).

Bao, Z., S. Sun, and D. Sun. 2015. Characteristics of direct $\mathrm{CO}_{2}$ emissions in four fullscale wastewater treatment plants. Desalination Water Treat. 54(4-5): 10701079.

Wang, J., J. Zhang, H. Xie, P. Qi, Y. Ren, and Z. Hu. 2011. Methane emissions from a full-scale A/A/O wastewater treatment plant. Bioresour. Technol. 102(9): 5479_ 5485. 


\section{DISCUSSION}

As the human population continues to grow, biological nitrogen removal (BNR) systems at both wastewater treatment plants (WWTPs) and onsite wastewater treatment systems (OWTS) will become increasingly common. Therefore, it is important that we determine the impact of these BNR systems on greenhouse gas (GHG) emissions. This research is among the first to apply an analyzer (Picarro G2508) that uses cavity ring down spectroscopy technology (Chapter 1) to measure the emission of three major $\mathrm{GHGs}\left(\mathrm{N}_{2} \mathrm{O}, \mathrm{CH}_{4}, \mathrm{CO}_{2}\right)$ from BNR systems.

The results of this dissertation indicate that although $\mathrm{N}_{2} \mathrm{O}$ emissions from both WWTPs and OWTS are generally low ( $<1 \%$ of $\mathrm{N}$ removed) they can be variable, resulting in high emissions at times (up to $21 \%$ of $\mathrm{N}$ removed for one OWTS) (Chapters 2 and 3). The large variability in $\mathrm{N}_{2} \mathrm{O}$ emissions was particularly clear in the re-aeration zone at the WWTP where emissions varied by over 4 orders of magnitude throughout the year (Chapter 2) and on one occasion $\mathrm{N}_{2} \mathrm{O}$ emissions from the re-aeration zone were 50 times greater in the afternoon than the morning (Appendix 1). Despite the large variation in $\mathrm{N}_{2} \mathrm{O}$ emissions, the results of this dissertation determined the zones (aerated IFAS at WWTP) and systems (WWTP and Advantex) where the highest emissions were observed, highlighting areas to focus emission reduction efforts (Chapters 2 and 3).

In addition to $\mathrm{N}_{2} \mathrm{O}$ emissions, this dissertation demonstrated the importance of measuring all three GHGs simultaneously as $\mathrm{CH}_{4}$ and $\mathrm{CO}_{2}$ emissions followed different trends than $\mathrm{N}_{2} \mathrm{O}$ emissions. While $\mathrm{N}_{2} \mathrm{O}$ emissions were generally low, this was not the case for $\mathrm{CH}_{4}$ and $\mathrm{CO}_{2}$ emissions. Methane emissions represented the 
largest proportion of the emissions from the BNR systems in the OWTS (Appendix 4). This is particularly important due to the high global warming potential of $\mathrm{CH}_{4}$ (28). However, at the WWTP, $\mathrm{CO}_{2}$ emissions were highest of the three gases (Chapter 2). This is significant because $\mathrm{CO}_{2}$ emissions are considered to be of biogenic origin by the Intergovernmental Panel on Climate Change and are therefore excluded from GHG budgets. However, a recent study concluded that part of the $\mathrm{CO}_{2}$ emissions from wastewater treatment may be of fossil (anthropogenic) origin and should therefore be included in budgets (detailed in Chapter 2).

In addition, when considering the emissions of all three GHGs at the centralized WWTP, the BNR system represented a significant proportion (12\%) of the total emissions of the WWTP (Chapter 2). Further, when emissions from the BNR system are compared to other sources of direct emissions (grit tanks, primary clarifiers, final clarifiers) the BNR tanks generally had the highest emissions of all three GHGs (Appendix 2). In combination, these findings indicate that the BNR tanks represent a significant proportion of the WWTPs direct GHG emissions.

The large variability observed in GHG emissions, especially $\mathrm{N}_{2} \mathrm{O}$, highlights the need to better understand the mechanisms responsible for emissions. Preliminary results from the isotopomer analysis indicate that nitrification is responsible for the $\mathrm{N}_{2} \mathrm{O}$ emissions at the WWTP and that there is not a difference in the source between the zones (Appendix 3). This is supported by the observation that amoA abundance (nitrification gene) was not significantly different between the zones (Chapter 3) and the inverse relationship between ammonium concentration and $\mathrm{N}_{2} \mathrm{O}$ emission (Chapter 2). Future research should focus on further understanding the mechanisms responsible 
for the emissions. Only then can operational changes be suggested in order to reduce emissions while maintaining $\mathrm{N}$ removal.

This research highlights the potential of BNR systems to be sources of $\mathrm{N}_{2} \mathrm{O}$, $\mathrm{CH}_{4}$, and $\mathrm{CO}_{2}$ indicating that increased $\mathrm{GHG}$ emissions may be a tradeoff of reduced $\mathrm{N}$ loads to coastal ecosystems. Increases in the human population will only exacerbate this issue and future studies will need to evaluate the implications of this tradeoff. 